\title{
Refugee Status Determination in Canada and the Path to Radical Reform
}

\author{
Pia Zambelli \\ Faculty of Law \\ McGill University, Montreal \\ November 2012
}

A thesis submitted to McGill University in partial fulfillment of the requirements of the degree of Master of Laws

CPia Zambelli, 2012 


\section{Table of Contents}

Abstract/Résumé ...........................................................................................................

Acknowledgments ......................................................................................................

Introduction ..............................................................................................................

Chapter 1:The Nature and Function of Refugee Status.............................6

Determination

1.1 Refugee status determination and its legal context.............................

1.2 Refugee status determination and its societal context ........................

1.3 The psychological context of refugee status determination.................11

1.4 Refugee status determination \& discourse theory ...............................14

1.5 The peculiar nature of refugee status determination............................21

1.6 The current structure and approach of the refugee status............. 21 determination process in Canada

Chapter 2: Sites of dysfunction in Canada's refugee status .....................25 determination system

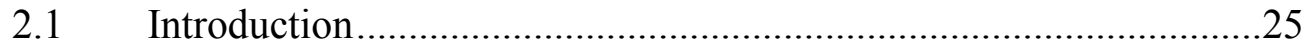

2.2 Voiced criticisms of Canada's refugee system …………..................27

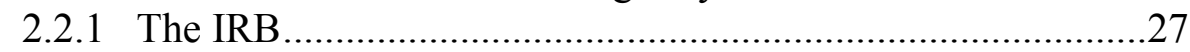

2.2.2. Inadequate error correction ...................................................30

2.2.3 Complexity and slowness ......................................................

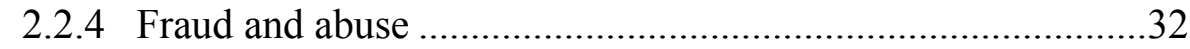

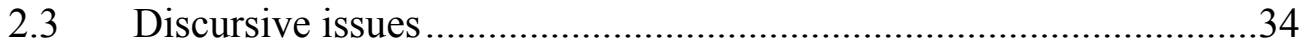

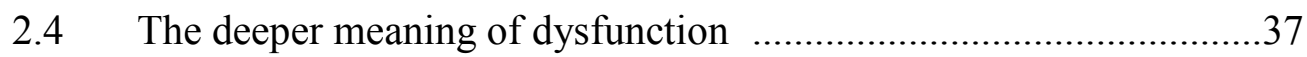

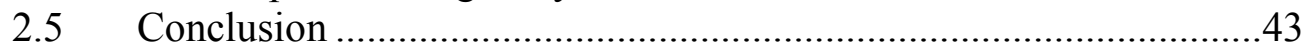

Chapter 3: Reform of Canada's refugee status determination system ...44

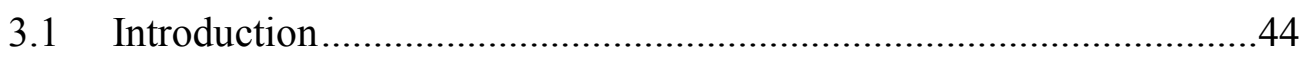

3.2 Other decision-making bodies and processes ........................................45

3.2.1.TAQ/administrative justice process ............................................46

3.2.2 Parole Board/parole process ………………….........................

3.2.3 The Tax Court of Canada / taxation appeal process ..................52

3.3 Describing legitimate structures and approaches ....................55

3.4 Reform Proposals for Refugee Status Determination............................57

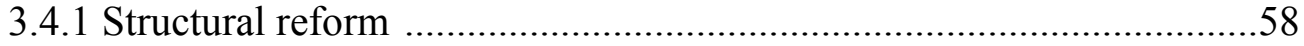

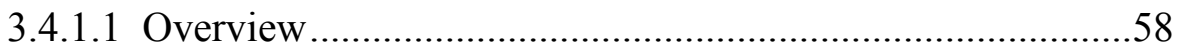

3.4.1.2 New site of initial determination.............................................58 
3.4.1.3 System Simplification ………………………….................68

3.4.1.4 New error correction mechanism..........................................71

3.4.1.5 Reasonable Timelines ........................................................77

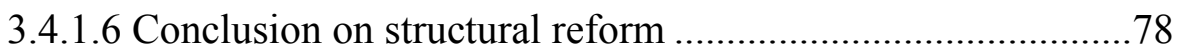

3.4.2 Ideological reform: new approaches to refugee determination.............79

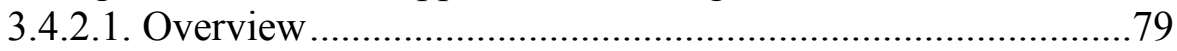

3.4.2.2 New decision-maker profile..................................................8

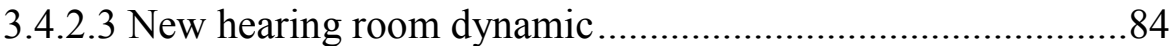

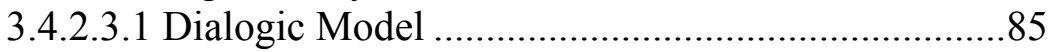

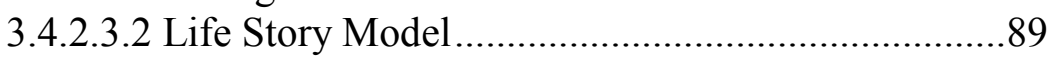

3.4.2.4 New approaches to credibility assessment ……………….....93

3.4.2.4.1 Coping with uncertainty.........................................93

3.4.2.4.2 Assessing refugee testimony...................................95

3.4.2.4.3 Borrowing and substitution ...................................99

3.4.2.5 Conclusion on ideological reform..........................................101

Conclusion ............................................................................................................103

Bibliography ..............................................................................................................105 


\begin{abstract}
This thesis presents a comprehensive structural and ideological reform proposal for refugee status determination in Canada designed to advance the interests of stakeholders. We propose an alternative model for refugee determination, new approaches to fact finding and credibility assessment in the asylum context, and a shift in systemic values. The alternative refugee status determination model proposed envisions moving from a quasi-judicial initial determination body to either a wholly-judicial one, similar to the Tax Court of Canada or a para-judicial/interdisciplinary one, similar to the Tribunal administratif du Québec. New approaches to fact finding and credibility assessment have centered on the notion that truth in the asylum context is relative, not fixed, and that dialogue and unfettered refugee speech should be privileged as much as possible in the hearing room. The new systemic values advanced have been accuracy (achieved through undistorted reception of information and dissemination of high quality contextual information), efficiency (achieved through simplicity, economy and timeliness being built into adjudicative structures) and juridical sensitivity to context (achieved through appropriate selection criteria, context-specific interdisciplinary training, and the fostering of a juristic culture around asylum decision making). The proposals find their inspiration in empirical data, interdisciplinary academic thought and previous reform initiatives, and are designed to conform to the challenges inherent in refugee status determination.
\end{abstract}

\title{
Résumé
}

La présente thèse soumet des propositions de transformations structurelles complètes et de réformes idéologiques du processus de reconnaissance du statut de réfugié au Canada. Ces propositions sont conçues pour promouvoir les intérêts des parties prenantes. Un nouveau modèle du processus de reconnaissance du statut de réfugié, de nouvelles approches en matière d'enquête et d'évaluation de la crédibilité dans le contexte de demande d'asile, ainsi qu'un changement des valeurs systémiques sont proposés dans la présente thèse. Pour modifier le processus de reconnaissance du statut de réfugié en vigueur, il est suggéré de mettre sur pied un modèle qui repose sur un organisme entièrement judiciaire, similaire à la Cour canadienne de l'impôt, ou sur un organisme parajudiciaire ou interdisciplinaire, comme le Tribunal administratif du Québec, pour remplacer l'actuel organisme quasi judiciaire chargé d'effectuer la détermination initiale. Les nouvelles approches en matière d'enquête et d'évaluation de la crédibilité sont axées sur la notion que la vérité, dans le contexte de la demande d'asile, est relative et qu'elle n'est pas établie. Dans la mesure du possible, on devrait également privilégier le dialogue et la libre parole des réfugiés dans la salle d'audience. Les nouvelles valeurs systémiques mises de l'avant sont : la précision (apportée par la réception de renseignements non faussés et par la diffusion d'informations contextuelles de haute qualité); l'efficacité (assurée par la simplicité, l'économie et la rapidité mises sur pied dans les structures d'arbitrage); et la sensibilité de l'appareil judiciaire au contexte (exprimée par la sélection de critères appropriés, par une formation interdisciplinaire propre au contexte et par la promotion d'une culture juridique entourant le processus de prise de décision en matière d'asile). Ces propositions puisent leur inspiration dans des données empiriques, des réflexions universitaires interdisciplinaires et des initiatives antérieures de réforme. Elles sont conçues pour s'adapter aux défis inhérents au processus de reconnaissance du statut de réfugié. 


\section{Acknowledgements}

I would like to express my deep gratitude to my thesis supervisor, Professor Evan Fox-Decent, for his many insightful comments and invaluable suggestions. I would also like to thank Professor Payam Akhavan, for the time and careful consideration which he brought to the task of reviewing this thesis. Without the input of these two persons, this thesis, in its current form, would simply not have been possible. Thanks is due as well to the excellent faculty at McGill law school; their teaching certainly assisted with my thesis by encouraging me to examine the law (both as it is and as it could be) through the lens of other disciplines, such as philosophy and literature. Finally, I frankly acknowledge that my thesis is based, to large extent, on the work of the many people across the world who have devoted their talents to the study of refugees and asylum seekers. I am ashamed to say that, despite having spent 25 years in the practice of immigration and refugee law (5 of which as a member of the Immigration and Refugee Board of Canada), prior to beginning my thesis, I had no idea of the breadth and depth of the research that exists in this area. I hope that this collective wisdom will someday be put to good use - and it is in this spirit that I present the reform project outlined in this thesis. 


\section{Introduction}

In 2010 the government of Canada began the process of implementing a 540 million dollar "reform" of the refugee status determination system. ${ }^{1}$ Although certainly dissatisfied with the status quo, refugee advocates were highly critical of many of the proposed changes, feeling that the government was taking the asylum system in the wrong direction. Their criticism begged the question: if the government's direction was wrong, then which direction would be right? This thesis attempts to provide an answer to this question, not in the hope that this answer will necessarily be seen as complete and definitive, but in the hope that it will initiate a more constructive debate around refugee status determination in Canada - one that goes beyond negativity and criticism and ventures into the realm of positive, workable visions for change. In Chapter 1 of this paper, we will explain the various dimensions of refugee status determination, the contexts in which it operates and the ways in which it functions in Canada and elsewhere. In Chapter 2 we will look at dysfunctional elements of the Canadian system. Finally, in Chapter 3 we will put forward some proposals for reform that attempt to address the dysfunction identified in Chapter 2 in light of the functional realities considered in Chapter 1. These reform proposals strive to find their basis in solid things: common sense, the tried and true, empirical evidence, academic thought and the needs of stakeholders. In terms of everything that Canada's asylum system is, has been and will soon be, this thesis aims to take the reader on an imaginary journey in a radically different direction.

\footnotetext{
${ }^{1}$ The Canadian government reform project notably calls for changing initial decision makers to bureaucrats, instituting an internal appeal mechanism, creating a truncated process for claimants from "safe" countries of origin, mandatory detention of maritime group arrivals and restrictions on refugee claimants' access to Canada's public healthcare system. See Balanced Refugee Reform Act S.C. 2010, c 8; Protecting Canada's Immigration System Act, SC 2012, c 17 (Bill C-31); Order Respecting the Interim Federal Health Program 2012, April 25, 2012 PC 2012-433 SI/2012-25, as amended. Cost estimates are from Citizenship and Immigration Canada: "Backgrounder: Bill C11,the Balanced Refugee Reform Act" (June 29, 2011), online: http://www.cic.gc.ca/english/department/media/backgrounders/2010/2010-06-29.asp)
} 


\section{Chapter 1: The Nature and Function of Refugee Status Determination}

\subsection{Refugee status determination and its legal context}

Refugee status determination is one of Canada's international obligations. In response to the humanitarian disaster of the Holocaust and World War II, the 1951 Convention on the Status of Refugees was drafted. The Convention is considered to be a human rights instrument. Refugee status is construed as a form of surrogate protection. If the home country is not protecting the human rights of some of its citizens by subjecting them to persecution, then it is up to the international community to step in and assume this responsibility by taking these citizens in-at least until such time as the home country does prove able to fulfill its responsibilities. But despite their humanitarian underpinnings, asylum procedures are usually packaged as part of the host state's immigration system. In other words, refugees are dealt with and regarded by the general population of the host state as a type of migrant. While there may be a certain logic and practicality to this approach, it does prove detrimental in some ways. While the refugee Convention in one sense represents the triumph of human rights over barbarism, construing the refugee as a migrant who arrives spontaneously without prior authorization engenders the fear of alterity. The refugee-figure is thus at the same time someone with whom we empathize and someone whom we distrustsomeone who shares our common humanity and someone who is the "Other". As we shall see, the tension implicit in this duality pervades every aspect of refugee status determination and must be addressed when contemplating reform.

The Convention's definition of "refugee" is long and complex. A Convention refugee is any person who

owing to a well-founded fear of being persecuted for reasons of race, religion, nationality, membership of a particular social group or political opinion, is outside the country of his nationality and is unable or, owing to such fear, is unwilling to avail himself of the protection of that country; or who, not having a nationality and being outside the country of his former habitual residence as a result of such events, is unable or, owing to such fear, is unwilling to return to it. ${ }^{2}$

\footnotetext{
${ }^{2} 1951$ Convention Relating to the Status of Refugees, 189 UNTS 137, art.1A(2).
} 
This definition comprises some eleven different elements, each with several subelements, and also contains some exceptions and exclusions. ${ }^{3} \quad$ Mastery of the definition and all its various components could take a lifetime. Yet decisionmakers are required to apply with this complex definition on a daily basis. It is therefore essential that they have the tools to do so adequately.

Aside from the legal complexity involved in applying the definition, there is another crucial difficulty inherent in the refugee status determination obligation. Refugee claimants coming to a host state must undergo some sort of examination process (either an interview or a hearing, or both) in order for their status to be determined. Their personal situation must be assessed and weighed against the Convention refugee definition, and therefore their assertions and statements must be evaluated. Usually undocumented, the refugee's oral narrative (the "story") is often the only tool available to the person examining an asylum claim. Thus, inherent in the examination process is the assessment of the overall credibility of the refugee and his or her story. In fact, in this context, there is little, if any, distinction between fact-finding and credibility assessment. Credibility assessment is one of the most difficult tasks in the legal system under the best of circumstances-yet the circumstances of refugee claimants are amongst the worst of circumstances. As we shall explore later in some detail, such things as fear, trauma, mistrust and culture shock, as well as the vagaries of cross-cultural communication and institutional skepticism conspire to make assessment of credibility in the refugee context a nearly impossible task. Put it all together and it is no wonder a United States Court of Appeals judge once wrote: "Asylum petitions of aliens seeking refuge from alleged persecution are among the hardest cases faced by our courts." 4 Any reformed system must have the capacity to face this reality.

\footnotetext{
${ }^{3}$ Ibid, Article $1 \mathrm{C}, 1 \mathrm{E}$ and $1 \mathrm{~F}$

${ }^{4}$ Xue v. Board of Immigration Appeals 439 F.3d 111(2006) at 4.
} 


\subsection{Refugee status determination and its societal context}

In addition to the legal challenges posed by the refugee Convention itself, it is essential to consider the broader anthropological, historical, social, economic, cultural, psychological and even philosophical contexts in which refugee status determination takes place when attempting to address systemic reform. Identifying asylum's place with society can help inform the choice of systemic structure. For instance, the relative importance of the institution of asylum as well as societal attitudes towards it may dictate the amount, quality and nature of community resources to be devoted to choosing asylees. Likewise, a working knowledge of the psychology of exile, the characteristics of narrative and the ways in which they intersect with the fundamental principles of the justice system can help identify the best approaches and practices in a refugee status determination system.

Asylum has deep roots, as old as civilization itself. In her recent book, Linda Rabben addresses the anthropological aspects of asylum:

Certain generalizations may be made about sanctuary and asylum. Human cultures are characterized by diversity and variety, and the apparently contradictory tendencies both to exclude and to integrate strangers seem widespread in our species. As a result, it is incorrect to assume that human nature leads inevitably to rejection of the Other. We are as likely to accept strangers as to drive them away, depending on complex factors that cannot be reduced to the immediate self-interest of a particular group. Sanctuary and asylum may be informally or spontaneously given, but they are rule-bound institutions based on shared values and well-established cultural codes....

Giving refuge to the stranger is an act of reciprocal altruism, an adaptation we share with our primate relatives and other species. It may have its roots in the avoidance of incest and the practice of exogamy in various species....

The altruism at the root of asylum is an evolutionary advantage in its potential for reciprocity; the helpful acts are costly to the giver in the short-term, but are performed in the expectation that, even at some time far in the future, the receiver will return the favour. ${ }^{6}$ Asylum has undergone a long historical development in European culture. Certain Greek temples, most notably the temple of Diana at

\footnotetext{
${ }^{5}$ Linda Rabben, Give Refuge to the Stranger: the Past, Present and Future of Sanctuary (California: Left Coast Press, 2011) at 53.

${ }^{6}$ Ibid, at 44 .
} 
Ephesus, were considered places that were inviolable ("asylos") for slaves, political exiles, outcasts and notorious criminals alike, subject to the judgment of the deity's priest. The Hebrews established six "cities of refuge" reserved for those who had committed unpremeditated murder. In medieval times, the Church controlled the institution of sanctuary (the forerunner of asylum) and established a complex set of procedures and rules for granting it even in defiance of the will of secular rulers. During the Renaissance and beyond, sanctuary gradually morphed into the secular and political institution of asylum as we now know it. The change coincided with the decline of religion as an organizing principle and the concomitant ascendance of the sovereign nation-state. Throughout history, the pendulum can swing from asylum being a categorical imperative based on shared humanity to asylum being a political decision based on line-drawing, and back again. Here again is the duality of asylum: both a human rights issue and an issue of politics and sovereignty, both a vision of the refugee as fellow individual human being and as part of a mass of outsiders. Any reform proposal must take a position on line- drawing and balancing of both sides of the asylum dichotomy.

As Matthew Price writes, “Asylum's historical function was to immunize fugitives against unjust punishment". $\quad$ Two pertinent implications of this function come to mind. First, as an institution, asylum is a form of opposition to injustice because injustice is inhumane. As Price notes, "Persecution is a destructive type of harm that calls for confrontation and condemnation". ${ }^{8}$ Second, asylum's function cannot be separated from the exercise of judgment: the punishment faced by the person fleeing must be adjudged to be unjust or undeserved. Thus, as long as there has been asylum, there has been asylum determination-including, presumably, a determination as to whether the asylum seeker is being truthful. Testing the veracity of the need for asylum is nothing to be ashamed of; rather, it must be embraced as an indispensable part of any process model.

\footnotetext{
${ }^{7}$ Matthew Price, Rethinking Asylum: History, Purpose and Limits (New York: Cambridge University Press, 2009) at 52.

${ }^{8}$ Ibid, at 14.
} 
Asylum is also situated within a broader socio-economical context that is important to understand for law reform purposes, particularly where reform intends to be based at least partly on stakeholder interests. We cannot deny that refugees are newcomers. As indicated earlier, they arrive spontaneously without prior authorization for the most part. From a socio-economic point of view, when refugees enter the host-country's territory, they are, to some extent, competing for resources with its existing population. In the context of the advanced welfarestate, the perceived competition would not be so much for food, water or shelter, but for the ever-scarcer public funds that need to be spent on administration or entitlements. In other words, new additions to the population may necessitate public spending (for example, on legal aid) that would or could be directed elsewhere (such as to public healthcare). If the overall percentage of refugees is small, then competition is not much of an issue. However, where the overall percentage of refugees is great (or perceived to be great, even falsely), this competition becomes more acute and a sense that group well-being is threatened may arise. ${ }^{9} \quad$ Refugee status determination reform initiatives must recognize the potentially inflammatory nature of asylum from a political and socio-economic standpoint, and take particular care to ramp down emotions and ensure objectivity. From this perspective, it is critically important that asylum determination be governed, not by arbitrariness, discretion and executive order, but by judicial function and the rule of law.

The asylum system is also a place where cultures intersect. The asylum seeker's status as "Other" has profound implications for the ability to communicate reasons for needing asylum. The most basic impediment is

9 In common parlance, "refugees" and "welfare" are words that are often uttered in the same breath. For instance, the following comment was made by a Canadian MP recently in a House of Commons committee hearing on reforms to the refugee system:

Ms. Roxanne James:

We had witnesses come in and talk about our welfare system yesterday. Just as a side note, you were asking about the costing behind this particular bill. It costs Canadian taxpayers $\$ 170$ million for abandoned claims from the European Union. That's per year. When I talk about $95 \%$ of them being abandoned, that is the actual monetary amount it costs people like you and me and all the constituents in my riding of Scarborough Centre. It costs them, hard-working Canadians, to foot that bill of $\$ 170$ million.

Do you think that's fair to taxpayers?

House of Commons, Standing Committee on Citizenship and Immigration, $1^{\text {st }}$ Sess, $41^{\text {st }}$ Parl, Evidence of Meeting 36, May 2, 2012 at 1250 (Hon Roxanne James). 
linguistic. Almost all communication must be with the aid of an interpreter or translator, greatly increasing the possibility of misunderstanding or distortion of the refugee claimant's statements. Furthermore, as Walter Kalin pointed out almost 30 years ago, the phenomenon known as "culture shock" greatly affects the asylum seeker's manner of expression:

Especially in the case of refugees from Third World countries, the experience of culture shock obviously can gravely impair the applicant's ability to make a forceful statement: Such an asylum seeker may speak in a confused, nervous, fragmented and unconvincing manner not because he or she is lying but because of the anxiety and insecurity caused by the difficulties of life in an entirely new social and cultural environment. ${ }^{10}$

Kalin goes on to note that concepts, time-perception and even the very nature of truth and falsehood are culturally relative. Even seemingly simple words like "brother" can mean different things in different cultures. Some cultures attach critical importance to precise time measurements and others do not. Likewise, cultural structures and value systems differ widely. For instance, the value placed on personal mobility and mobility rights means that physical distance between even immediate family members is quite normal in North American society. But in some cultures, it is socially impossible to leave one's native village or to live outside the family structure. This is particularly true for women, where in some places a woman living alone is assumed to be a prostitute and therefore at high risk of sexual assault. A reformed process must therefore be well adapted to interculturality by privileging open-mindedness, ontological diversity and bridgebuilding.

\subsection{The psychological context of refugee status determination}

There are psychological factors at play in refugee status determination as well as socio-economic and cultural ones. Refugeehood and exile implies a certain state of mind. First and foremost, the refugee claimant may already be traumatized by subjugation to state violence, and the quest for asylum from persecution brings with it additional and different forms of trauma, such as

\footnotetext{
${ }^{10}$ Walter Kalin, "Troubled Communication: Cross Cultural Misunderstandings in the AsylumHearing”, (1986) 20:2 International Migration Review 230 at 232.
} 
separation from family members and social standing issues both with respect to host community members and fellow compatriots in exile. As several researchers have pointed out, the exile suffers from such things as incomplete emotional processing, uncertainty, fear, depression, somatic symptoms, identity crisis, existential dilemma, psychic isolation, liminality, cultural bereavement as well as the culture shock already described. ${ }^{11}$ Stuart Turner in particular describes a crisis of trust, whereby the exile who has been the victim of state violence is no longer able to have a normal relationship with the state and eventually loses the ability to trust anyone at all. ${ }^{12}$ A significant proportion of exiles also suffer from post-traumatic stress disorder (PTSD), which is characterized by sleeplessness, nightmares, suicidal ideation, panic attacks, intrusive thoughts, etc. ${ }^{13}$ As Caroline Moorehead writes

Depression has been observed in up to 90 percent of people who have been displaced and post-traumatic stress disorder in about 50 percent; many people who have been tortured have also suffered injury to the brain from beatings to the head, suffocation, near drowning and starvation. There is, it appears, something singularly traumatic about the combination of forced exile and extreme violence. At no moment is that combination more disabling than at the moment of arrival in a safe place, when the asylum seeker, frozen in a state of insecurity, not knowing whether he will be allowed to stay or be deported, denied access to

\footnotetext{
${ }^{11}$ Alan Desantis, "Caught Between Two Worlds: Bakhtin's Dialogism in the Exile Experience", 14:1 Journal of Refugee Studies (2001) 1; Ilene Durst, "Lost in Translation; Why Due Process Demands Deference to the Refugee's Narrative" (2000) 53:1 Rutgers L Rev 127; Marita Eastmond, "Stories as Lived Experience: Narratives in Forced Migration Research" (2007) 20:2 Journal of Refugee Studies 248 ; Jane Herlihy \& Stuart Turner, "The Psychology of Seeking Protection" (2009) 21:2 Int'l J Refugee L 171; Lawrence Kirmayer, "Failures of Imagination: The Refugee's Narrative in Psychiatry"(2003) 10:2 Anthropology \& Medicine 167; . John Chr Knudsen, "When Trust is on Trial: Negotiating Refugee Narratives" in E Valentine Daniel \& John Chr Kndusen, eds, Mistrusting Refugees (Berkeley: University of California Press, 1995) 13; Stuart L Lustig, "Symptoms of Trauma among Political Asylum Applicants: Don't be Fooled" (2008) Hastings International and Comparative Law Review 725; Cecile Rousseau \& Patricia Foxen, "Constructing and Deconstructing the Myth of the Lying Refugee: Paradoxes of Power and Justice in an Administrative Immigration Tribunal" in Els Van Dongen \& Sylvie Fainzang, eds Lying and Illness: Power and Performance (Amsterdam: Het Spinhuis, 2006) 56; Cecile Rousseau \& Patricia Foxen, "Look me in the Eye: Empathy and the Transmission of Trauma in the Refugee Determination Process" (2010) 47 Transcultural Psychiatry 70; Cecile Rousseau, Francois Crépeau, Patricia Foxen \& France Houle, "The Complexity of Determining Refugeehood: A Multidisciplinary Analysis of the Decision-making Process of the Canadian Immigration and Refugee Board" (2002) 15:1 Journal of Refugee Studies 43; Amy Shuman \& Carol Bohmer, "Representing Trauma: Political Asylum Narrative" (2004) 117:466 Journal of American Folklore 394.

${ }^{12}$ Stuart Turner, "Torture, Refuge and Trust" in E Valentine Daniel \& John Chr Kndusen, eds, Mistrusting Refugees (Berkeley: University of California Press, 1995) 56.

${ }^{13}$ Lustig, supra, note 11 at 725 .
} 
work or study, assailed by memories of loss and brutality, oscillates on his bridge, unable to go back or to proceed. And it continues to be disabling, during the long limbo of the asylum process, when those who wait, condemned to passivity and uncertainty, experience feelings of being disliked and despised, which in turn feed existing feelings of failure and valuelessness. ${ }^{14}$

In order to deal with these emotional difficulties, the refugee claimant may feel compelled to employ a number of different strategies. Once such strategy, as explained by Alan DeSantis, is dialogic thinking (the thought process of negotiating past and present in dialogue form) which encompasses four dialogic struggles: the struggle to define one's emotional/psychological state, the struggle to define one's social identity, the struggle to define one's sentiments and loyalties and the struggle to define the future. ${ }^{15}$ In response to identity crisis, identity management measures such as a strategic presentation of self may be resorted to. ${ }^{16}$ And a very common response to emotional difficulties is silence or laconic speech when required to testify about the reasons for flight. ${ }^{17}$ In fact, as Rousseau, Crépeau and Foxen point out, "trauma can alter the account of experience in a number of ways"18 including distorted spatial and temporal perception, dissociation, blocked memory and difficulty concentrating. ${ }^{19}$ As we will eventually explore in detail, all the psychological tendencies at play in refugee status determination must be well understood and a successful model for refugee status determination must have adaptations built-in for these tendencies.

\footnotetext{
${ }^{14}$ Caroline Moorehead. Human Cargo (New York: Henry Holt \& Company 2005) at 226.

${ }^{15}$ Desantis, supra note 11 at 6-14.

${ }^{16}$ Knudsen, supra note 11 at 29.

${ }^{17}$ Ibid, 25.

${ }^{18}$ Rousseau, Crépeau, Foxen \& Houle supra, note 11 at 48.

${ }^{19}$ It is not just the asylum seeker whose psychology has consequences for the process. Various authors have identified several psychological hurdles faced by refugee status decision-makers as well. These include cultural barriers, a preference for the familiar, the tendency to avoid or to disbelieve stories evincing pain, brutality or the suggestion that chaos is the reigning principle of the universe, and a rigid mindset (such as one where the police and authority figures are inherently trustworthy, where everything is susceptible of scientific proof, where truth is fixed as opposed to variable, where dates are important, where story telling must be chronological, rational, linear and closed-ended)as well as vicarious traumatisation and falling prey to a culture of disbelief as a defence mechanism. (see Durst, supra, note 11, Rousseau, Crépeau, Foxen \& Houle, supra, note 11, and Kirmayer, supra, note 11).
} 


\subsection{Refugee status determination through the lens of discourse theory}

Aside from the historical, anthropological, socio-economic, cultural and psychological perspectives we have briefly discussed, it is also essential to recognize the centrality of narrative in refugee status determination. As noted earlier, an asylum seeker often comes with little else in the way of evidence of persecution than his or her own story. Thus, the outcome of the asylum process is dependent on how the story is told and how the listener responds to it. As such, it would seem crucial that a successful refugee status determination system acknowledge itself as the site of a discursive process. Once the parameters of this discursive process are defined, systemic structures can be created or adapted to fit within them. Academic literature on refugee narrative provides invaluable insight in this regard.

One of the first scholars to apply discourse theory to refugee status determination was Robert Barsky. Barsky studied the way refugee claimants represent themselves and are represented through language. For Barsky, refugee claims were ideal fodder for such a study, "characterized as they are by complex discursive processes such as cross-cultural communication, interpretation (and translation), codified legal procedure, transcription and confession."20 Barsky postulated that refugee discourse is so tightly controlled by adjudicative structures that the refugee claimant cannot represent his authentic self to decision-makers: "In this sense the claimant is truly an 'Other'; he must select (or invent) information which make him out to be what we want him to be; and any deviation from this path is grounds for closing off the discourse, or even rejecting the claim."21

In order to better understand refugee discourse it is useful to begin with Marita Eastmond's insightful explanation of the relationship between truth, experience and expression. She distinguishes between 1) "life as lived" (what has actually occurred); 2) "life as experienced" (how the subject interprets what has occurred); 3) "life as told" (how the subject articulates what has occurred);

\footnotetext{
${ }^{20}$ Robert Barsky, Constructing a Productive Other: Discourse Theory and the Convention Refugee Hearing (Philadelphia: John Benjamins Publishing Company, 1994) at 1.

${ }^{21}$ Ibid, at 131.
} 
and 4)"life as text" (how what has occurred is represented in writing). ${ }^{22}$ Upon further reflection, it becomes apparent that these can be transposed to the facets of refugee narrative: first, the cold, hard (and ultimately unascertainable) facts; second, the internal "spin" which the claimant puts on the facts; third, the way the facts are related, including what facts are omitted or changed, and finally, the written account of the facts which is presented to the decision-making authorities.

Within this general discursive context, we must take into account the ways in which refugee discourse is affected by trauma and the psychological state of exile referred to above. Refugee claimants speak from a position of fear and insecurity. Furthermore, as we have seen, they are continually negotiating and renegotiating their past experiences vis-à-vis their present emotional, physical and social situation in the host country-in short, all throughout their claims (and beyond) they are in the midst of the attempt to make themselves whole again. The essentially dialogic, fluctuating, liminal and variable nature of the exile's thought process is therefore reflected in his or her discourse. The discursive process may be dictated by a strategic presentation of self whereby, as noted in the work of Amy Shuman and Carol Bohmer,

The narrative elements that might be extraneous to the...decision process are often significant for the claimant's sense of self. Driven by a desire to present themselves as credible, some claimants emphasize loyalty to their homelands rather than fear of return, and others draw upon memories of a time when life itself was more coherent. For some applicants, describing oneself as a victim of persecution is incompatible with recovering a sense of dignity or personal integrity following a trauma. ${ }^{23}$

In other words, the content of any statement made may be dependent on the claimant's emotional state at the time this statement is made. This emotional state may fluctuate throughout the claim process. It could be different upon arrival, during waiting periods, at the hearing and after the outcome. This variability of emotional state and its impact on refugee discourse would seem to militate in favour of an approach to fact finding and credibility assessment that tends to see truth as relative, rather than absolute.

\footnotetext{
${ }^{22}$ Eastmond, supra, note 11, at 249.

${ }^{23}$ Shuman, supra, note 11, at 406. See also Knudsen, supra, note 11 at 29: "A life history is not a story of life but rather a conscious or even unconscious strategy for self-presentation”.
} 
It should further be recognized that, for refugee claimants, sometimes speech itself is impossible. Their experiences may be unspeakable or even unthinkable. As Jon Knudsen noted while studying resettled Vietnamese refugees in the Netherlands,

As a hedge against exposure and consequent adverse transformation of one's self-identity in public discourse, refugees retain their strategy of withdrawal and restricted conversation...Silence continues to be held as the basic way of handling bereavement and loss. ${ }^{24}$

There is a certain irony here. Narrative is at the center of refugee status determination, yet narrative is exactly what many refugee claimants have difficulty producing. Many claimants who have been raped or tortured are not able to speak of their experience. Their reluctance to speak may itself be a way of expressing their sense of horror, shame and victimization. Thus, refugee silence becomes an aspect of refugee speech that should be capable of finding official recognition in the determination process.

As with all narration, there is also the question of voice. Refugee speech is odd in that the asylum seeker is almost never heard speaking in his or her own voice. Even with "life as told" (such as, say, testimony at the refugee status determination hearing), in the vast majority of cases the voice that is heard and understood by the decision maker (and a reviewing court upon transcription) is that of the interpreter. Even assuming completely accurate translation, the interpreter chooses the vocabulary, intonation, phrasing, emphasis, and sometimes even what is said or left unsaid. Likewise, if we are dealing with written applications, court affidavits or interview notes ("life as text") the final product might evidence several voices - namely, those of the claimant, translator, interviewer and counsel. The input of counsel in particular should not be underestimated in this regard. The asylum seeker usually does not have the verbal skills required in the host language to produce a narrative in text form without assistance. When assistance is provided, i.e. when a text is created for signature by the asylum seeker, the text will necessarily reflect the drafter's own assumptions and viewpoint vis-à-vis the asylum seeker's story. Consciously or

${ }^{24}$ Knudsen, supra, note 11 at 25 . 
unconsciously, a person drafting a text on behalf of a refugee claimant will tend to fill in logical or temporal gaps, frame events in a different and more coherent way, omit things deemed irrelevant, embellish or dramaticize the narrative, or -in extreme cases - even provide a substitute life story. Usually this "poetic license" is motivated by the best of intentions: to secure safe haven for a person in trouble; but nonetheless the unintended consequence is to distort or even silence the refugee's authentic voice and to replace the discourse of the Other with discourse that is culturally familiar. ${ }^{25}$

Refugee speech is also, at least in some sense, opportunistic speech. The drive to find a safe haven is paramount. As Barsky notes:

To rethink the subject in immigration discourse is to realize that he/she is trying to root him or herself in a place which will legitimize his or her rights to an acceptable level of status; and to that end he/she is willing to take extraordinary measures (tearing up passports in the airplane and eating them) or say incredible things he/she thinks will help achieve this goal. ${ }^{26}$

For Barsky, the sorts of statements that will result in safe haven are not necessarily true statements ("life as lived"), but those that meet the preordained criteria for asylum. Thus, refugee claimants will tend to tell decision-makers what the latter need to hear from a legal standpoint. There is nothing surprising about refugee opportunism. Self-preservation is instinctual and the ability to

25 This phenomenon of substitutional voice in the asylum process was explored recently in Dinaw Mengestu's novel, How to Read the Air (New York: Riverhead Books, 2010) at 21, 24. The main character, Jonas, describes his work with asylum seekers at a New York City legal aid clinic in this way:

My job at the center was to read through the asylum statements as soon as they came in....In time I was given the job of editing out the less credible or unnecessary parts of some of the narratives, while at the same time pointing out places where some stories could be expanded upon or magnified for greater narrative effect... I took half-page statements of a coarse and often brutal nature and supplied them with the details that made them real for the immigration officer who would someday be reading them... It was easy to find the necessary details; they resurfaced all over the world in various countries, for different reasons and at different times. I quickly discovered as well that what could not be researched could just as easily be invented based on common assumptions that most of us shared when it came to the poor in distant, foreign countries...(p 21)

When Jonas decides to return one such embellished statement to its original form, the clinic's senior lawyer rejects it immediately (p 24).

${ }^{26}$ Robert Barsky, "Narratology and the Convention Refugee Claim: Re-ontologizing the subject in Canadian Immigration Hearings discourse" (1988) 1:3 Discours Social 265 at 284. 
engage in strategic self-preservation is a distinct advantage. Self-editing of discourse is common. ${ }^{27}$

Strictly speaking, then, refugee speech may well be false speech. This lack of authenticity is also an aspect of refugee discourse and it may be time to simply acknowledge it. Yet, it would seem essential to recognize that there may be several distinct reasons why "life as lived" does not coincide with "life as told" or "life as text" in the asylum context. First, the asylum seeker may knowingly provide a fabricated narrative. There is anecdotal evidence that this practice is widespread and organized, and, while it is beginning to be discussed more openly, the exact dimensions of the problem are not currently ascertainable by empirical evidence. What we do know, however, is that, based on admissions made by claimants themselves, there may be more than one reason why individuals submit false histories. For instance, some may be fortune seekers unable to immigrate legally. A New York Times article ${ }^{28}$ makes the following reference:

Amadou Diallo, the street vendor from Guinea who was shot 41 times by New York police officers in 1999, came from a well-off, stable family. But he told immigration authorities that he was from nearby Mauritania, and that his parents had been killed in that country's conflict. It was not true, but he was granted asylum. The scheme was revealed after his death.

Others apparently use false stories because they do not feel the account of their true problems is dramatic or dire enough. An article in The New Yorker profiled "Caroline", an asylum seeker who pretended to have been raped. ${ }^{29}$ She had obtained a ready-made story from a "story shaper", and even went so far as memorizing the symptoms of post-traumatic stress disorder (in order to obtain a medical report from a torture clinic $)^{30}$ and conjuring up tears during her asylum interview when she spoke of the rape. Ironically, though, this young woman had actually had problems in her home country. Her parents had been supporters of

\footnotetext{
${ }^{27} \mathrm{We}$ have only to think of our own behaviour in certain high-stakes situations. For instance, is it not commonplace to fail to declare the true extent of items purchased abroad to customs officials? To omit certain unflattering facts in a job interview? To cast our children in the best possible light when called in by the school principal?

${ }^{28}$ Sam Dolnick, "Immigrants May Be Fed False Stories to Bolster Asylum Pleas" The New York Times (11 July, 2011).

${ }^{29}$ Suketa Mehta, "The Asylum Seeker: For a chance at a better life, it helps to make your story worse", The New Yorker (1 August, 2011) 32.

${ }^{30}$ Doctors have denied that they can be duped like this. See Lustig, supra, note 11 at 729 .
} 
an opposition leader and, in pursuit of her father, soldiers had ransacked their home and beaten her brother. Her sister had been forced to run away with a nail stuck in her foot. When her family later came to the United States for a wedding, Caroline decided to remain. She was advised by members of her community that her story was not dire enough, and to adopt the (true) stories of other asylum seekers who had gone before her as her own:

A clerk in Caroline's lawyer's office had suggested "Why don't you say you were circumcised?" Caroline told her that female circumcision wasn't practiced in her country. So she had learned how to play a rape victim. She has pangs about lying: "Telling that story makes me sad, because I know it's true for someone". 31

Absent any evidence of victimization, we cannot support what Amadou Diallo did. But it would be only natural to have a mixed reaction to Caroline. We might consider her a brazen liar, a victim of poor advice, just someone seeking a better life, or someone simply doing what was expected of her-i.e. describing her experiences in a way that would reconstruct her as someone deserving of asylum. After all, as Cynthia Hardy has pointed out, according to the Foucauldian tradition, the human subject is produced or constructed through discourse, and the refugee status determination process is "a discursive fiction and, as such, constructs a reality rather than revealing it". ${ }^{32}$ Thus, if refugee claimants borrow someone else's story or substitute a different story for their own, they are not automatically to be condemned. A borrowed story is put to good use: the person it belonged to never made it out alive, and the claimant presents himself or herself as a surrogate. Presenting a substitute story of persecution, the claimant is merely speaking in metaphor-speaking in a way that the receiving society can more readily understand. ${ }^{33}$ A functional refugee status determination system must be one that is open to thinking about refugee narrative in these sorts of ways and one that is able to find ways of grappling with fact finding in the complex discursive context we are describing. These must include reliable ways of

\footnotetext{
${ }^{31}$ Mehta (The New Yorker), supra note 29 at 32.

${ }^{32}$ Cynthia Hardy, "Refugee Determination: Power and Resistance in Systems of Foucauldian Power" (2003) 35:4 Administration and Society 462 at 482.

${ }^{33}$ Desantis, supra, note 11 at 6.
} 
identifying fraudulent discourse as well, for the host society is under no obligation to tolerate deliberate fabricators in the asylum system.

Aside from deliberate deception, refugee speech may also be false or inaccurate because of two aspects of human nature - the limits of memory and the tendency to exaggerate. As Hilary Cameron has pointed out, ${ }^{34}$ the human memory is highly fallible, particularly in the refugee context where what is being recalled are traumatic events experienced in a distant place, in a distant time while in a state of fear. Accordingly, tying credibility determinations in the asylum context to memorial accuracy would seem doomed to failure. The account given by the refugee claimant at any given time in the process is not likely to be accurate, cogent, cohesive, consistent or coherent, particularly with regard to dates and details. The context virtually ensures a disconnect between "life as lived", "life as experienced" and "life as told". Exaggeration, on the other hand, is best understood by realizing that by necessity, the refugee claimant is cast first and foremost as a storyteller, and exaggeration is a natural (and even essential) part of storytelling. As we have seen academics argue, the narrative process is itself a way for the asylum seeker to reconcile the past and the present and to rehabilitate his or her own identity and self esteem under difficult circumstances. Thus, in a refugee claim, it is relatively easy to see how one arrest may multiply to two or three, or how a ten minute beating may increase to thirty-perhaps as a way of attempting to emphasize the painfulness of the experience. Fortunately, the tendency to exaggerate is tolerated (and even expected) in refugee law and should not normally result in an adverse decision. ${ }^{35}$ Nonetheless, it is not always easy to draw a line between exaggeration and deliberate deception, and there may be embellishers that find themselves disbelieved.

This vast potential for inauthenticity in refugee speech which we have just explored is multi-faceted and merits comprehensive and informed consideration within the asylum process. While not becoming immune to or accepting of the

\footnotetext{
${ }^{34}$ Hilary Evans Cameron, "Refugee Status Determination and Limits of Memory" (2010) 22:4 Int'l J Refugee L 2010469.

${ }^{35}$ Yaliniz v Canada (Minister of Employment and Immigration) (1988), 7 Imm LR (2d) 163, at 164 (FCA) followed in Ozer v MCI 2008 FC 1257; Grama v MCI 2004 FC 1030.
} 
Amadou Diallos of the world, the asylum process should ideally be able nonetheless to adjust for faulty memory and exaggeration and find ways to address the root causes of borrowing and substitution. Recasting refugee status determination as a discursive process in which narrative is central may well prove to be a useful starting point.

\subsection{The peculiar nature of refugee status determination}

What peculiarities of refugee status determination have we been able to identify? Our discussion has revealed that seeking asylum is a process that is historically and anthropologically rooted, socio-economically significant, legally complex, politically-charged, cross-cultural, emotional, psychologically sensitive, traumatic, narrative based, and afflicted by an authenticity deficit. It is a process that is full of contradictions. It appeals to both our higher and baser instincts. It is a process of strife and struggle - struggle of cultures, mindsets, values and ways of knowing. It demands that we confront the dichotomy of the refugee-figure as both "us" and "Other". A successful refugee status determination system would therefore be one which, in both structure and approach, is fully able to cope with these challenges. As we have suggested, the system should be able to accommodate legal complexity, strike an appropriate balance between alterity and parity in the refugee-figure, understand the narrative process, make room for the psychology of exile, and privilege interculturality, authenticity and objectivity. But it should equally be capable of accurately identifying those who deliberately fabricate claims of persecution that have no basis in reality and removing them from consideration for asylum.

\subsection{The current structure and approach of the refugee status determination process in Canada}

We will now turn to an examination of the basic structures of the asylum process currently in place both in Canada and elsewhere. Under the Canadian system, refugee claims made at the border are subject to triage by border officials 
(including, notably, an interview at the port of entry) and are then referred to the Immigration and Refugee Board (IRB), a quasi-judicial administrative tribunal, for an oral hearing on the merits. The hearing takes place before a panel of IRB members, who are not civil servants, but political appointees. Some 63.4 million dollars was spent by the IRB on refugee protection in $2010-2011 .^{36}$ If refused, the claimant has a right to apply to the Federal Court for judicial review of the IRB decision. This review has suspensive effect, but is subject to a leave requirement. ${ }^{37}$ Leave is granted in between 10 and $25 \%$ of cases and there is no appeal from a denial of leave. If leave is granted and judicial review is successful, the case is referred to the IRB for a redetermination. A decision of a Federal Court judge can be appealed to the Federal Court of Appeal if the case involves a serious question of general importance. If recourse to the courts proves unsuccessful, the claimant may apply to Citizenship and Immigration Canada (CIC) for a Pre-Removal Risk Assessment (PRRA) —a form of subsidiary protection-and/or permanent residence on humanitarian and compassionate grounds. If decisions are negative on both or either of these applications, the claimant has the right apply for judicial review in the Federal Court, but - againonly with leave. The filing of judicial review proceedings does not have suspensive effect in the latter circumstances, but there is a general right to seek a stay of removal from the Federal Court. Accordingly, it can easily be three or four years (or sometimes as many as six years) before a refugee claimant in

\footnotetext{
${ }^{36}$ Immigration and Refugee Board of Canada, Performance Report 2010-2011 (Ottawa: Immigration and Refugee Board, 2011) at 30.

${ }^{37}$ The leave requirement was introduced in 1989. Prior to that, all judicial review under immigration legislation was as of right. The leave requirement was an initiative of the government, and was based on a refugee status determination model developed by Rabbi Gunther Plaut when he was commissioned to create a new refugee status determination system that complied with constitutional requirements. (See note 90 below). The leave requirement does not appear to have been brought in at the request of the Courts, which had previously been judicially reviewing negative asylum decisions as of right under either section 18 or section 28 of the previous Federal Court Act without incident. For an extensive history and analysis of the leave requirement see Sean Rehaag, "The Luck of the Draw? Judicial Review of Refugee Determinations in the Federal Court of Canada" (2005-2010)" (2012) 8:3 Osgoode CLPE Research Paper Series 1.
} 
Canada has exhausted all available remedies. The wait time at the IRB alone has ranged between 14 and 21 months in recent years. ${ }^{38}$

During the course of the process just described, an asylum seeker will encounter various actors. The first will likely be an immigration or border official to whom the asylum seeker will almost always be required to make a statement, usually with the help of an interpreter either in person or over the telephone. Detention of refugee claimants is relatively infrequent, so the asylum seeker will usually be released into the community at large, where he or she may make contact with family, other members of his or her ethnic community, or NGOs. The next move will normally be to find a lawyer and access any social services (health care, welfare, legal aid etc.) that may be required and available. ${ }^{39}$ The initial status determination hearing takes place in a hearing room at the offices of the IRB. The players at the hearing are claimant, lawyer, interpreter, and Board member. The structure of the hearing is non adversarial. The players are seated in a circular formation, with the decision-maker on a slightly raised dais. There is no "prosecutor" or government representative whose job it is to argue against the granting of refugee status per se. Conversely, for refused claims, proceedings before the Federal Court are fully adversarial, with a government lawyer arguing in favour of upholding the IRB decision. Supplementary recourses such as PRRA and humanitarian applications are separate, wholly administrative processes, and decisions are made by immigration officers, usually without meeting the claimant. $^{40}$

\footnotetext{
${ }^{38}$ Immigration and Refugee Board of Canada, Performance Report 2010-2011, supra, note 36 at 16.

${ }^{39}$ Refugee claimants are eligible for last resort financial assistance in every province of Canada usually until removal. However, Legal Aid is not available in all provinces. The Federal government provides for health care coverage during the most of the claim, but has discontinued this for some claimants and for all rejected claimants as of June 29, 2012 pursuant to a reform initiative (see note 1 , supra).

${ }^{40}$ As mentioned at the outset of this paper, in 2010 and 2012 the Canadian government proposed changes to the refugee status determination system. IRB hearings will be required to take place within approximately 75 days of arrival, unless the claimant is deemed to be from a "designated country of origin" (i.e. a safe country), in which case the hearing will be held within 45 days of arrival. An additional layer of process has also been added in the form of an internal appeal before the Refugee Appeal Division (RAD). First tier refugee decision makers at the IRB will no longer be term political appointees, but civil servants instead, and there is no statutory requirement that any of them be legally trained. RAD members will be term political appointees, at least $10 \%$
} 
The cast of characters in the asylum process is essentially the same in all signatory states. Although the process may vary internationally in terms of the various levels of process, all systems have at least one level of initial examination of the facts (usually performed by functionaries), at least one level of error correction (usually performed by the judiciary or individuals with legal training) and the possibility of accessing subsidiary protection regimes. ${ }^{41}$ The same basic examination approach appears to be followed globally as well: the asylum seeker is required, usually through an interpreter, to explain his or her claim first in writing and then orally at a kind of "trial" where he or she is face to face with decision-makers. The key issue is whether asylum is warranted and this involves an assessment of credibility as well as the application of legal rules.

Canada's asylum procedure stands out from the crowd in one important respect. In Canada, initial examination of claims is performed by a quasi-judicial body that is independent of the government, whereas in the other systems this function is performed by an administrative agency. In fact, it has been said that the distinctive feature of Canada's refugee system is that it invests most of its resources in the first level determination - the "do it once, do right" theory. This approach is commendable - essential, even. The only problem is, as we shall see in the next chapter, that it does not seem to be working to anyone's satisfactionsuggesting that, for all its promise, the system is failing to adequately cope with the challenges of refugee status determination outlined above.

of whom must be lawyers. The appeal will normally be disposed of in writing. If the RAD appeal on the merits is not successful, the claimant would then seek leave for judicial review of the refusal. The PRRA will no longer be readily available to most claimants and access to humanitarian and compassionate relief will also be limited. See Balanced Refugee Reform Act and Protecting Canada's Immigration System Act (Bill C-31), supra, note 1.

${ }^{41}$ For instance, in the United States, initial examination is performed by Asylum Officers or Immigration Judges (who work for the Justice Department and may or may not be legally trained). In the UK, Europe and Australia/New Zealand initial examination is performed by civil servants. In terms of error correction, the US has the Board of Immigrations Appeals (BIA) and then the federal Circuit Courts of Appeal. In the UK, error correction is consecrated to the two levels of the Asylum and Immigration Tribunal (AIT) and then to the Courts; in New Zealand, to the legally trained members of the Immigration and Protection Tribunal (IPT) and then to the Courts; and in Australia to the Refugee Review Tribunal (RRT) $-50 \%$ of whose members are lawyers - and then to the Courts. See University of Ottawa, Human Rights Research and Education Centre, Refugee Forum, National Asylum Systems (2010), online: http://www.cdp-hrc.uottawa.ca/projects/refugeeforum/projects/systems/introduction.php 


\title{
Chapter 2: Sites of dysfunction in Canada's refugee status determination system
}

\section{$2.1 \quad$ Introduction}

Canada's refugee status determination system has been the object of criticism virtually from its inception in 1989 - from both within and without. ${ }^{42}$ The IRB, in particular, is viewed as not having lived up to expectations. As well, the system is frequently described openly as overly expensive and rampant with abuse and fraud. ${ }^{43}$ This unease is partly reflected in the fact that the Canadian government is continually tinkering with the process - there have been major legislative amendments introduced in 1989, 1993, 2002, 2010 and 2012 - and in the high rate of appeal of negative IRB decisions. ${ }^{44}$ Put it all together and it creates a sort of "spin". And that "spin" is that Canada's refugee determination system is chronically broken and in constant need of repair.

\footnotetext{
${ }^{42}$ The criticism referred to is largely comprised of public comments made by either by academics, refugee advocates (lawyers and NGOs), government officials or sometimes refugees themselves. These comments have been made in the context of either scholarly articles or books, Parliamentary structures (such as committee hearings, or House of Commons debates) or transmitted through the media (newspapers, television and, more recently, websites).

${ }^{43}$ It is the government and some NGOs that tend to make these sorts of statements. See for instance, “Tories Aim to Fix 'Broken' Immigration System”, CTV News (February 16, 2012), online: http://www.ctv.ca/CTVNews/TopStories/20120216/refugee-reform-bill-immigrationchanges-120216 which reads:
}

\begin{abstract}
Immigration Minister Jason Kenney said that it takes about 1,000 days for the Immigration and Refugee Board to review a claim filed by someone from a democratic rights-respecting country. That would be reduced to 45 days under the proposed changes. "We're saying the party's over," said Kenney, who noted that current refugee claimants can access federal programs like welfare and health care. Kenney estimated that the reforms would save $\$ 1.5$ billion over the next five years. "It's costing billions," he said.
\end{abstract}

See also Martin Collacott “Canada's Inadequate Response to Terrorism: The Need for Policy Reform”(2006:Fraser Institute), which indicates:

Failure to exercise adequate control over the entry and the departure of non-Canadians on our territory has been a significant factor in making Canada a destination for terrorists. The latter have made our highly dysfunctional refugee determination system the channel most often used for gaining entry. ... Making a refugee claim is used by both terrorists and criminals as a means of rendering their removal from the country more difficult.

\footnotetext{
${ }^{44}$ This assessment of the rate of appeal is based on anecdotal evidence.
} 
This perception is not entirely accurate. Canada has had reasonably high acceptance rates, ${ }^{45}$ several forms of subsidiary protection and some of the best social conditions for refugee claimants (relatively little detention and immediate eligibility for a work permit, healthcare, welfare and legal aid where available). The concept of the IRB (an independent, quasi-judicial administrative tribunal of first instance) is a good one. As an institution, the IRB has many excellent attributes, such as an extensive documentation center, high-quality governance and an impressive body of guidelines on special issues such as vulnerable claimants and gender-based persecution. The system is generally compliant with international obligations. ${ }^{46}$ Yet, somehow, the complaints persist—leading to the conclusion that there is a serious problem below the surface that needs to be addressed.

We will begin the analysis by examining voiced criticisms from media, practitioners and academics in an attempt to identify the most dysfunctional elements of the asylum process. Viewing the asylum system as a discursive process in line with academic thought will further illuminate the areas of dysfunction. Finally, we will again look at the system through a socio-economic and political lens, in order to assess its overall legitimacy in terms of advancing

\footnotetext{
${ }^{45}$ Canada's acceptance rate has traditionally been around $45 \%$. (This figure is based on statistics provided to the Canadian Council for Refugees by the IRB and not for public dissemination). In 2010, the UK's rate was 25\%, France 14\%; Sweden: 38\%; Italy 31\% (see "Asylum Lottery in the EU European Council for Refugees and Exiles (ECRE), online: http://www.ecre.org/. Australia's acceptance rate was 43\% in 2010-2011. See Australian Government, Department of Immigration and Citizenship, Asylum Trends Australia 2010-2011 Annual Publication (Canberra: Systems, Program Evidence and Knowledge Section of the Department of Immigration and Citizenship (DIAC)) at 20.

${ }^{46}$ UNHCR, "Note on fair and efficient asylum procedures: a non-exhaustive overview of applicable international standards" (2005). Canada is clearly in compliance with 8 of 12 guidelines. The system is generally accessible. There are no time limits for claiming. The right to counsel is respected. Interview reports are disclosed. Country of origin information is collected and widely referred to. Decisions are supported by reasons. Confidentiality is preserved and there are special provisions for children and UNHCR observance. However, it could be argued that Canada is not perfectly compliant with the requirement of a central decision-making authority for all refugee-like claims, the requirement that the decision-making authority be "composed of qualified individuals well versed in the use of interpreters and cross-cultural interviewing techniques as well as the effects of trauma" and the existence of an "effective remedy" against refusals.
} 
stakeholder interests. This panoramic view of the problems with asylum in Canada will assist in determining the direction of eventual reform initiatives.

\subsection{Voiced criticisms of Canada's refugee status determination system}

\subsubsection{The IRB}

The locus of many of the complaints around Canada's refugee status determination system is the IRB itself-specifically the quality of the IRB decision-makers. As indicated earlier, IRB members are political appointees for terms not exceeding ten years. There are no particular member-qualifications guaranteed in the IRPA, except for the requirement that at least $10 \%$ of members be lawyers. $^{47}$ The list of qualifications for Governor-in-Council appointees as advertised on the IRB website simply states:

Candidates must have experience in working with members of diverse communities or have been exposed to different cultural perspectives. Candidates must also have experience in one or more of the following:

Working in a decision-making environment; Presiding at committees, hearings or meetings; Implementing or interpreting legislation respecting the security or protection of persons; Working in a field of human rights or refugees; Working in an investigation, adjudication, mediation, or conflict resolution capacity. ${ }^{48}$

Traditionally, the appointment process with respect to federal administrative tribunals has been afflicted by patronage - the practice of rewarding friends and campaign staff of cabinet ministers and other highly placed federal government officials. Thus, IRB members have traditionally not been selected exclusively on merit. A mini-crisis even developed over this issue almost 20 years ago when the Board was referred to as a "Kangaroo Court" and "the Refugee Star Chamber" in

\footnotetext{
${ }^{47}$ Immigration and Refugee Protection Act S.C.2001 c.27 section 153(4). Government reforms will make IRB members civil servants with no minimum percentage of lawyers see Balanced Refugee Reform Act, supra, note 1, section 26.

${ }^{48}$ Immigration and Refugee Board of Canada, "Employment", online: http://www.irbcisr.gc.ca/eng/brdcom/empl/memcom/Pages/soq.aspx (as it read prior to reforms referred to in note 47 supra)
} 
the media and an independent review had to be commissioned. ${ }^{49}$ In this report, Professor James Hathaway determined that far too many IRB members were "unfit to exercise their responsibilities by reason either of simple incompetence or a negative attitudinal predisposition" and that a shift to a meritocratic system needed to begin immediately. ${ }^{50}$

While there has been a serious attempt to rectify this phenomenon (by a new hiring process and by requiring that members possess the job qualifications listed on the website as referred to above), Hathaway's recommendation was never fully implemented and there has been little change in the negative perception of the quality of IRB members over the years. As Audrey Macklin wrote in 2009, "There is little doubt that the overall level of competence is lower than what might have been achieved from a purely merit-based system..."51

In terms of academic thought on the question, Kirmayer believes that IRB members suffer from "failures of imagination". 52 Rousseau, Crépeau, Foxen and Houle more explicitly identify legal, psychological and cultural factors as being at the heart of IRB dysfunction. ${ }^{53}$ In their evaluation of 40 IRB cases, they found that members had difficulty administering and assessing the evidence, understanding the political and social conditions in other countries, interpreting administrative and international law and understanding the rules of politeness and decorum. They also found "massive avoidance of traumatic content," and secondary trauma symptoms, as well as significant rates of cultural misunderstanding, prejudice and stereotyping. ${ }^{55}$ But like Kirmayer, they note that

The inability to fathom life in other cultures, or even the plight of refugees in Canada, also creates false expectations of cultural coherence at a more general

\footnotetext{
${ }^{49}$ James Hathaway, Rebuilding Trust : Report of the Review of Fundamental Justice in Information Gathering and Dissemination at the Immigration and Refugee Board of Canada, December, 1993, online: repository.forcedmigration.org/pdf/?pid=fmo:1136

${ }^{50}$ Ibid, at 37,39

51 Audrey Macklin, "Asylum and the Rule of Law in Canada: Hearing the Other (Side)" in Kneebone, Susan, ed, Refugees, Asylum Seekers and the Rule of Law (New York: Cambridge University Press, 2009) 78 at 96-97.

${ }^{52}$ Kirmayer, supra, note 11.

${ }^{53}$ Rousseau et al, “The Complexity of Determining Refugeehood”, supra, note 11.

${ }^{54}$ Ibid, at 64.

${ }^{55}$ Ibid at 64
} 
level, often reinforcing an atmosphere of suspicion and leading to the assumption of contradiction and non-credibility. ${ }^{56}$

A further study of the IRB conducted by Crépeau and Nakache ${ }^{57}$ argues that the IRB has never truly succeeded in becoming a so-called "critical space" i.e. "a forum where ideas can be constructively debated, free from any pressure from the powers that be, supported by a consensus on the importance of the deliberation and a common understanding of its operative principles". 58 According to the authors, such critical spaces are crucial to the development of institutional professionalism. ${ }^{59}$ One aspect of this problem not identified by Crépeau and Nakache, but which is still troubling, is the IRB's failure to develop any sort of body of citable jurisprudence in its over 20 years of existence. This phenomenon might suggest that the IRB does not conceive of itself as having a "law-making" function. It might also suggest that IRB decisions are so divergent as to be impossible to rationalize into a coherent body of opinion. ${ }^{60}$ Either way, what may be implied is a lack of serious engagement with its subject matter-in other words, a deficit of professionalism. On a deeper level, concerns around members' qualifications and the lack of professionalism at the IRB also seem to point to something else-namely, a lack of juristic culture. In other words, the existence of these sorts of problems suggests that, essentially, the quasi-judicial IRB is not acting judicially enough. This is an area which must be adequately addressed in any reform project. $^{61}$

\footnotetext{
${ }^{56}$ Ibid at 62 .

${ }^{57}$ Francois Crépeau \& Delphine Nakache, "Critical Spaces in the Canadian Refugee Determination System; 1989-2002” (2008) 20:1 Int'l J Refugee L 50.

${ }^{58}$ Ibid at 52 .

${ }^{59}$ Ibid at 53.

${ }^{60}$ For a study of the variation in acceptance rates among IRB members see Sean Rehaag, "Troubling Patterns in Canadian Refugee Adjudication" (2006) 39:2 Ottawa L Rev 1.

${ }^{61}$ The Canadian government's 2010-2012 reform efforts would seem to have the opposite effect: they see refugee status determination made less of a judicial process, rather than more of one, in that first instance asylum decisions will be made by bureaucrats instead of quasi-judicial appointees. See Balanced Refugee Reform Act, supra note 1, section 26. However it is interesting to note that the job qualifications for the more bureaucratic refugee deciders under the reforms would appear to be much more juristic than those for the current political appointees. The "PM06 " level functionary is required to have recent experience either rendering decisions, presenting cases or conducting research or investigations in a quasi-judicial or judicial process as well as a degree in law, public administration, international relations, refugee studies or migration studies.
} 


\subsubsection{Inadequate error correction}

Another dysfunctional element in the refugee status determination system raised in critiques is the lack of an effective error correction mechanism. Because of the dissatisfaction with IRB decision making, it is only natural that the question of appeal routes would naturally come to the forefront. As noted earlier, Canada's current system devotes most of its resources to the first-level decision by entrusting this task to an independent quasi-judicial tribunal, in the hopes of "getting it right the first time," so to speak. Following along with this philosophy, Canada then feels justified in restricting access to judicial review of the first level decision by imposing a leave requirement, presumably under the assumption that the first level hearing is of such high quality that its results will rarely need correction. Although other countries have leave requirements for judicial review, ${ }^{62}$ such judicial review is occurring only after an independent quasijudicial tribunal has reviewed the initial administrative decision. Thus, Canada appears to be the only country that does not allow some sort of a review as of right with respect to the initial asylum decision. ${ }^{63}$ Even if leave is granted, what is available is only judicial review for error of law (unreasonableness) and not an appeal on the merits. Thus, the Court can only send cases decided erroneously back to the IRB; it cannot render the decision that ought to have been rendered in the first place.

The leave requirement has come under intense scrutiny over the years. It has been challenged in court, to no avail. ${ }^{64}$ Yet, Audrey Macklin has noted that the leave requirement "directly and incontrovertibly breaches" the right to "access to an independent and impartial court" which is one of the "foundational tenets of

See Public Service Commission of Canada, online: https://psjobs-emploisfp.psc-cip.goc.ca/psrssrfp (accessed September 21, 2011). Time will tell whether different qualifications will make for more satisfactory decision-making in asylum cases, or whether the bureaucratic nature of the position will result in less decisional independence and continued problematic outcomes.

${ }^{62}$ For instance, Australia, which has a leave requirement to get directly to the High Court from the Refugee Review Tribunal (RRT) and from the Federal Magistrate's Court to the High Court. See University of Ottawa, Refugee Forum, supra, note 41.

${ }^{63}$ However, recent reforms include the implementation of an internal appeal division of the IRB, known as the Refugee Appeal Division (RAD). The effectiveness of this appeal mechanism is questionable, given that the RAD will be staffed by the same political appointees currently hearing refugee claims at first instance at the IRB - creating the "old wine in new bottles" scenario.

64 See Bains v MEI (1990) 109 NR 239 (FCA); Krishnapillai v MCI [2002] 3 FC 274 (CA) 
the rule of law". ${ }^{65}$ Studies of Canada's leave requirement have shown widely divergent grant rates among individual judges ${ }^{66}$ and grant rates based on factors unrelated to legal issues, such as the gender and country of origin of the applicant. ${ }^{67}$ Because of the leave requirement and the absence of an appeal on the merits, ${ }^{68}$ the perception appears to be that meaningful error correction cannot take place in Canada's refugee status determination system. This would therefore constitute another major area for reform.

\subsubsection{Complexity and slowness}

Yet another criticism levelled against Canada's asylum process is that it incorporates a multiplicity of proceedings and is therefore too slow and too complex. This criticism is made to some extent by both refugee advocates as well as government. In fact, much of the legislative tinkering has been in this area. $^{69}$ Given that Canada can see as many as 20,000 to 30,000 claims in one year, scheduling initial determination hearings promptly has proven extremely difficult. Yet, claimants consistently mention how difficult it is for them to wait long periods of time (sometimes up to two years) for their initial hearing, because of feelings of liminality:

"You're always nervous, you're always stressed, you are not comfortable because you're still not part of anything. You're not part of your country

\footnotetext{
${ }^{65}$ Macklin, supra, note 51 at 104-105.

${ }^{66}$ Ian Greene \& Paul Shaffer, "Leave to Appeal and Leave to Commence Judicial Review in Canada's Refugee Status Determination System: Is the Process Fair?” (1992) 4 Int'l J Refugee L 71; Sean Rehaag, "The Luck of the Draw?” supra, note 37.

${ }^{67}$ Jon Gould, Colleen Sheppard \& Johannes Wheeldon, “A Refugee from Justice? Disparate Treatment in the Federal Court of Canada” (2010) 32 Law \& Pol'y 454.

${ }^{68}$ The proposed Refugee Appeal Division of the IRB would have jurisdiction to review refusals on the merits and even hear new evidence. Balanced Refugee Reform Act, supra, note 1, s 13(2). While theoretically constituting a meaningful reform of error correction, the RAD will be staffed with the same political appointees as the current RPD and need only be comprised of $10 \%$ lawyers - thus calling into question its effectiveness.

${ }^{69}$ Timelines related to refugee claims and appeals were introduced in 1989 and maintained in subsequent legislation. In 1993, error correction was moved from the Federal Court of Appeal to the Federal Court, Trial Division. In 2002, single-member IRB panels became the norm. The 2010 and 2012 reforms require refugee hearings to be set down within 75 days of arrival and require appeals to the Refugee Appeal Division to be perfected within 15 days.
} 
anymore because you cannot go back there, and you're not part of where you are...." 70

Some reported stress so severe, they experienced physical side effects. But, as we have seen, the claim process does not end with the IRB hearing: subsidiary forms of protection are available as well and are subject to review by the Courts. In this way, a single asylum claim can entail three separate proceedings before the federal courts - not to mention ancillary applications for stays of removal. The availability of these multiple recourses and reviews lengthen the process considerably—sometimes for over five years, as we have seen. ${ }^{71}$

From the perspective of the asylum seeker, the multiple proceedings are commenced in an attempt to rectify an unreasonable and incorrect denial of safe haven. From the government and community perspective, the complex structure allows the refugee claimant to indefinitely delay his or her deportation at the taxpayer's expense. The underlying concern is that, for every long-term refugee claimant who is on welfare, has health problems, makes use of legal aid, or accesses the justice system, there is a corresponding financial cost. Furthermore, for every long-term refugee claimant who is undesirable (a criminal or a terrorist) there is a corresponding social cost. It is therefore entirely valid for reform to seek to address the question of streamlining the system - both for the sake of the claimants themselves and in the interests of community well-being. ${ }^{72}$

\subsubsection{Fraud and Abuse}

The final major complaint heard about Canada's asylum process is that there is a high incidence of fraud and abuse. In some sense, this is true. As we have seen in the previous chapter, there is, technically, an element of falsity in

\footnotetext{
${ }^{70}$ Canadian Council for Refugees, The Experience of Refugee Claimants at Refugee Hearings at the Immigration and Refugee Board, (7 January, 2012), online: http://ccrweb.ca/files/irb_hearings_report_final.pdf at 11.

${ }^{71}$ Peter Showler, Fair Fast and Final: Reforming Canada's Refugee System, (Ottawa: The Maytree Foundation, 2009) at 8.

72 The Canadian government's 2010-2012 reform package is in line with these suggestions. Access to PRRA and humanitarian relief has been significantly curtailed — only available on certain grounds and/or after a significant period of time has elapsed since the claimant was refused. See Balanced Refugee Reform Act, supra, note 1, s 15, and Protecting Canada's Immigration System Act (Bill C-31), supra note 1, ss 13 and 38.
} 
much of refugee speech for a variety of complex reasons. Arguably, the most objectionable form of this falsity is, as noted earlier, the situation of claimants who have no problems at home and simply fabricate a refugee claim because they cannot otherwise enter Canada either as immigrants or foreign workers. ${ }^{73}$ It is clearly undesirable for claimants to deliberately deceive and consciously misrepresent themselves - to tell these "aggressive falsehoods"- and the asylum process might legitimately be said to be dysfunctional in so far as it fails to reject these fraudulent claims. From a socio-economic and anthropological perspective, feelings of betrayal and anger towards deliberate fabricators are as valid as feelings of compassion for the plight of genuine refugees, and it might seem right to go to considerable lengths to expose this behaviour. On the other hand, it is probable that most of those telling "aggressive falsehoods" may be nothing worse than fortune-seekers, who are prepared to say and do almost anything to lift themselves and their families out of poverty—much like virtually all migrants for thousands and thousands of years. The situation is further complicated by the fact that there is a lack of factual information on the incidence of "aggressive falsehoods" that remain undetected. Since the degree of dysfunction in this particular area is not actually known, and until more research is conducted, the assertion that out-and-out fraud is rampant within Canada's refugee status determination system can neither be affirmed nor denied. Whether to focus heavily on preventing asylum fraud when the exact dimensions of the problem are not even known is a choice for the host community to make and Canada, via its recent reforms, appears to have made this choice. But disproportionate emphasis on a problem that could conceivably be largely imaginary might also legitimately be said to be a form of dysfunction.

\footnotetext{
${ }^{73}$ Over the years there have been significant numbers of claimants who were admittedly bogus, For instance, in the late 1980's, there were large numbers of Portuguese nationals that went through the refugee system claiming to be persecuted Jehovah's Witnesses, although there was no basis for this assertion. During the same period, many Jamaican domestic workers who had overstayed their visitor's status also made claims as a way of stopping removal. In 2008, a group of Mexicans claimants arrived who later admitted they had been told by a travel agent that, if they sought asylum on arrival, they could vacation in Canada for several months and receive welfare benefits from the Canadian government at the same time.
} 
Nonetheless, as we have noted earlier, there is at least some evidence that many claimants do tell what we might call "protective falsehoods" (i.e. resort to metaphor, borrowing or embellishment) and even "inadvertent falsehoods" (through confusion, trauma or poor memory). There is a case to be made that the system is dysfunctional because of the very fact that claimants feel they must resort to "protective falsehoods" in the first place, as well as because of the fact that the "inadvertent falsehoods" are not recognize as such and can be so easily held against them. In terms of claimants frequently resorting to false statements in an attempt to secure safe haven, Barsky might argue that Canada's refugee determination system inadvertently encourages this behaviour. Time constraints, limitations on speech, narrow definitions, construction of the refugee-figure in discourse - all these things might be interpreted as encouraging the claimant to self-edit or to speak in handy metaphors, with the failure to do so possibly resulting in the rejection of the claim. ${ }^{74}$ In other words, if asylum seekers consistently receive the message, "You must be this", they will construct themselves as such. If they instead receive the message, "Tell us what you are", how different the process would be. There would presumably be no need for the "protective falsehoods" and the culture of disbelief-with its potentially devastating effect on those claimants who are actually telling the truth as they perceive it - might finally be dispelled.

\subsection{Discursive issues}

We have used commonly voiced complaints to identify the loci of dysfunction in Canada's refugee status determination system. But if we continue to look at the system as a discursive process (as Barsky did) we will reveal further layers of dysfunction.

Throughout the quest for protection in Canada, the statements made by the asylum seeker are myriad. First, there will be questions asked and answers

\footnotetext{
${ }^{74}$ Barksy, Constructing a Productive Other, supra, note 20, at 131.
} 
recorded at the port of entry upon arrival. Then, the claimant is required to provide an official written statement, also for presentation to the IRB. On the form currently provided for this purpose, claimants are provided with the definitions of both a Convention refugee and a protected person and are exhorted to create a "narrative" in which they are told to "set out in chronological order all the significant events and reasons that have led you to claim refugee status in Canada" ${ }^{75}$ For Barsky, these are mechanisms through which the state narrows and controls discourse. In addition, written statement preparation is usually done with the aid of a community contact, an interpreter, a lawyer or all three to varying degrees, and, as alluded to earlier, the opportunities for the refugee claimant's statements to be distorted in this process are vast. Some refugee claimants even hand in ready-made statements to their lawyers. This raises the suspicion (or should) that the statement was purchased and is therefore fabricated. The implication is that claimants have contact with other actors prior to seeing the lawyers and that these actors are exerting an influence on the claimants' statements - either by providing them with false stories that meet the refugee definition or by encouraging them to make alterations to their true stories that go beyond mere embellishments. Who these actors are is not entirely clear, but, as suggested in the New Yorker article about Caroline and her "story shaper" referred to earlier, they most certainly are persons who have knowledge of not only what decision-makers want to hear from asylum seekers, but also of conditions in the various countries of origin. ${ }^{76}$

When the refugee status determination hearing takes place, the claimant is then required to give oral testimony (through an interpreter, if necessary). There is inevitably a comparison made between the asylum seeker's testimony and his

\footnotetext{
${ }^{75}$ Immigration and Refugee Board of Canada, Personal Information Form, online: http://www.irbcisr.gc.ca/eng/tribunal/form/documents/form189_e.pdf

${ }^{76}$ One proposed change to Canada's refugee system was to replace the written form with a mandatory, formalized pre-hearing interview process with an IRB official about 15 days after arrival. See Balanced Refugee Reform Act (Bill C-11), supra, note 1, s 11(2)--repealed. Interestingly enough, the intention of these provisions appeared to be to obtain an "unfiltered" statement from the asylum seeker-i.e. one that has not been influenced by input from third parties. From the point of view of discourse analysis, this is actually an idea that has reformative potential, and it will be discussed below.
} 
or her previous statements. Given the typical Western mindset, all these statements must be consistent in order for the asylum seeker to be believed. When this is not the case, asylum is usually denied. Even if there is no issue with prior statements, the claimant's testimonial statements at the hearing must also conform not only to the host country's discursive paradigm, but to the legal requirements for Convention refugee status as well. Barsky sees the process as follows:

The information asked is purely empirical, chronological and absolutely related to the initial statement....The process encourages, nay, demands this kind of reduction and precision. There is no whole human being at the end of such a process; there is the Other as Convention refugee claimant, the Other as repetition and clarification of the original statement". ${ }^{77}$

If judicial review is sought, the claimant must make a further statement to the judge in the form of an affidavit. Lawyerly input into this statement is extensive and the voice of the asylum seeker is drowned out as the process shifts into the juridical world and the case becomes a battle over interpretation of legal rules. In fact, most refugee claimants never even see the judge deciding their cases face to face. By this point, according to Barsky, the claimant is "reduced from a human being to a narrative about his persecution in the country of origin, and this narrative has been passed to three different bodies who are trying to evaluate his 'credibility'...,"78

Narrative upon narrative upon narrative-this is the refugee status determination system as a discursive process. The system demands that all the narratives be consistent; yet as indicated in the academic literature on asylum, a person will almost never relate a story in the same way twice: the content will likely vary based on external variables, such as the audience, physical setting or access to memories. ${ }^{79}$ This is doubly true of exiles who, as we have seen, are burdened with dialogic thinking, liminality, and the effects of trauma. And those

\footnotetext{
${ }^{77}$ Barsky, Constructing a Productive Other, supra, note 20 at 218.

${ }^{78}$ Barsky, Constructing a Productive Other, supra, note 20 at 230.

79 Jane Herlihy, Peter Scragg \& Stuart Turner, "Discrepancies in autobiographical memoriesimplications for the assessment of asylum seeker: repeated interviews study", BMJ 2002:324:3247; Durst, supra, note 11, at 148.
} 
who pass through the process successfully are not necessarily those who are simply telling the truth. As Barsky notes,

The hearing is more of a test of the claimant's ability to sort through his experience for appropriate selection than it is an evaluation of whether or not his experience is in line with our definition of the Convention refugee. Whether the experiences are "true" or "false" is hereby subordinated to the larger concern of whether this individual has adequately assessed the requirements of this hearing... ${ }^{80}$

Examining Canada's refugee status determination system through the lens of discourse theory helps us more clearly identify the substance of the dysfunction; we can see more clearly where the areas of discord are. We can see that the process is closed, where openness is required; demands certainty where certainty is in short supply; is monologic where dialogism prevails; is overburdened with narrative where narrative is difficult, and is dependent on memory where memory is faulty. In short, what discourse analysis has helped to reveal is the ways in which the contours of our approach to asylum adjudication fail to conform to the contours of the experience of forced exile.

\subsection{The deeper meaning of dysfunction}

We have now identified the areas of dysfunction in Canada's refugee status determination using different approaches. By analyzing areas of voiced complaint, we were able to identify four dysfunctional elements: problematic decision making, inadequate error correction, slow pace and excessive complexity (and, therefore, cost) as well as an overall authenticity deficit. By taking the slightly wider perspective of discourse analysis, we have also been able to see that the system is quite problematic as a discursive process, suffering as it does from narrative overkill, closed discourse, monologism and overall disconnect with the peculiarities of refugeehood. But we need to take an even wider perspective;

\footnotetext{
${ }^{80}$ Barsky, Constructing a Productive Other, supra, note 20, at 119
} 
we must search for deeper meaning and unifying themes in the areas of dysfunction that have been identified. What is it precisely that is objectionable in these areas? What underlying expectations are not being met? To whom do these expectations belong? In exploring these questions, we might well stumble upon a partial answer to the question raised at the outset - namely, the question of why there seems to be so much dissatisfaction with a refugee status determination system that is, on its face, one of the best in the world.

As we have seen, asylum is a social institution. The asylum granting process is comprised of adjudicative structures around this institution. The stakeholders in the asylum granting process could be conceived as the legitimate asylum seekers ${ }^{81}$ on one hand and the host community ${ }^{82}$ on the other. When there is said to be dysfunction within the process, we may theorize that what is really being conveyed is that the institution of asylum is not serving its stakeholders. When there is objection to the quality of the IRB, to error correction mechanisms, to slowness and complexity, to the spectre of fraud and abuse, and to assessment of refugee narrative in general, stakeholders may be sending the message that certain needs are not being met, that certain values are not being recognized. In other words, whatever is currently objectionable about these aspects of the asylum process is a mirror-image of those needs and values. And once those needs and values are discerned, they can inform the process of reform.

At center, complaints about quality of decision-making, poor error correction, authenticity deficits and problematic discursive issues could be interpreted as complaints, not simply around fairness, but around accuracy. What seems to be happening is 1) that decision-makers are having difficulty

\footnotetext{
${ }^{81}$ Fortune seekers (i.e. persons posing as asylum seekers) cannot be counted in this stakeholder group. They have an interest in migrating, not escaping persecution or oppression. The asylum process was not established for their benefit and they have no say in it.

${ }^{82}$ The "host community" and "the government" are not necessarily identical. Neither Canada nor any other country for that matter is a direct democracy where all initiatives are implemented by referendum. Accordingly, the actions of the elected government representatives in such a system are not always the concrete manifestations of the wishes, aspirations or ideals of the public at large. It is therefore safer to avoid conflating the concerns of government and the concerns of the host community. The other problematic aspect of the notion of the "host community" is that it is not a homogenous group. However, for the purpose of identifying the needs and interests of this group, we will use majoritarian principles: the "host community" here refers to the majority of the Canadian public.
} 
identifying which claimants actually need protection and which ones are simply fortune seekers in disguise, and 2) that the structures in place are inadequate to correct these sorts of fundamental mistakes. From an accuracy standpoint, there has to be something wrong with a system whereby a Federal Court judge (sitting as an error corrector) is allowed, and even encouraged, to let a negative asylum decision which he or she personally thinks is wrong go unrectified. ${ }^{83}$ In order to ensure that determinations are accurate in the first place, decision makers need to be able to discern the refugee, discern conditions in his or her country of origin and discern the law. Accuracy in this context could therefore be seen to rest on information flow-information from the asylum seeker and other types of information, including legal and psychological information. It follows that anything that interferes with the flow of information or distorts it, risks compromising accuracy. Likewise, complaints about slowness and complexity can be interpreted as complaints around efficiency — which, after all, is defined as being effective without wasting time, effort or expense. In the context of the refugee status determination process, not wasting time implies processing claims with a reasonable time; not wasting effort implies keeping things simple; and not wasting expense implies doing both these things at once, since lengthy stays for claimants imply more social benefits paid out, and complex procedures mean more administrative and judicial resources expended. In this way, efficiency could be conceived as dependent on simplicity, timeliness and economy.

But the values of "accuracy" and "efficiency" are not all that seems to be missing. Most, if not all, of the complaints around Canada's asylum system appear to be complaints around something deeper-we might call it "judgment" or even "juridical sensitivity to context" - in other words, the ability of decisionmakers to be alert, alive and sensitive to the various legal principles and values at play in refugee status determination. Not only must the process see clearly and

\footnotetext{
${ }^{83}$ This happens frequently, because of the legal standard for judicial review. See for instance Molnar v MCI 2012 FC 530 where, in refusing to set aside a negative IRB decision involving a Roma family from Hungary who had been physically attacked several times, the judge stated: [105] The Hungarian situation is very difficult to gauge. Much will depend upon the facts and evidence adduced in each case, and on whether the RPD goes about the analysis in a reasonable way. Where it does, it is my view that it is not for this Court to interfere even if I might come to a different conclusion myself...
} 
act firmly and expeditiously, the process must be able to adjust for the complex legal and psycho-social ramifications of forced exile as well.

Could "accuracy", "efficiency" and "juridical sensitivity to context", then, be the buzz-words for reform? ${ }^{84}$ Could these be the fundamental values that stakeholders wish to see embodied in Canada's refugee status determination system? Does the lack of accuracy, efficiency and juridical sensitivity to context make the system appear illegitimate? We can begin to answer these questions by looking more closely at the interests of stakeholders (legitimate refugee claimants and the host community), and then attempting to see if the values of "accuracy", "efficiency" and "juridical sensitivity to context" jibe well with those interests and serve to advance them.

Asylum seekers are the raison d'être of the system and have the most to gain or lose once they enter it. What the genuine ones need is safe haven; for them the asylum process is entirely results oriented. No matter how superb the conditions or procedures, the system is dysfunctional to the extent that it fails to identify those truly in need of refuge. As we have argued, central to this accurate identification process is the claimant's ability to communicate his or her need for refuge, and the decision maker's receptiveness to and ability to interpret this information. In some sense, the legitimate asylum seeker is essentially asking the host community one question, and that question is: "Will you give me shelter from persecution?" The legitimate asylum seeker needs a clear and timely answer to that question, and delays, convoluted procedures and multiple recourses often fail to provide that. More importantly, the legitimate asylum seeker also needs to be dealt with on his or her own terms, to be more than superficially understood and to receive a judgment that reflects such an understanding. In this sense, the values of "accuracy", "efficiency" and "juridical sensitivity to context" mesh

\footnotetext{
${ }^{84}$ These underlying values do not differ significantly from those put forward in other reform projects. For instance, Peter Showler's key words were "fair fast and final", but he also uses the words "effective" and "efficient" (See Showler, Fair, Fast and Final, supra, note 71 at 9-10). The American Bar Association, in suggesting sweeping changes which will be referred to below, identified its preferred values as "independence", "fairness", professionalism" and "efficiency": See American Bar Association. Reforming the Immigration System: Proposals to Promote Independence, Fairness, Efficiency and Professionalism in the Adjudication of Removal Cases, 2010 at $6-4$.
} 
nicely with the interests of asylum seekers. They need the decision to be accurate, the process to be simple and timely, and the application of the law to the facts to be judicious and perspicacious.

The host community also has a significant interest in the asylum process. First, the host community, because of its core constitutive moral values, may have a genuine desire (we could even call it a need) to help the vulnerable "Other". This is not surprising; not only is a mixing of cultures genetically advantageous, ${ }^{85}$ we know from an anthropological standpoint that asylum is an act of reciprocal altruism. This need/ desire to help others might even be referred to in common parlance as the upholding of a "humanitarian tradition". 86 But attached to this desire to help is the corollary need for the host community to assure itself that this help is genuinely necessary, i.e. to verify that the asylum seeker is truly at risk. Second, the host community needs to assure itself that the asylum seeker is not a threat to its well-being, say, by being violent. Third, the host community needs to ensure that neither asylum seeker nor the asylum process, represent a drain on collective resources. In essence, the host community has a legitimate interest in both altruism and maintaining its physical and economic well-being and both these interests deserve to be advanced by the asylum process. The focus, for the host community is not only on adequate decision-making, but structural issues related to the process itself as well. Thus, the values of accuracy, efficiency and juridical sensitivity to context serve the host community as well as the genuine refugee. In concrete terms, identification of those legitimately in need should be accurate, the process should be simple, timely and economical and the decision to

\footnotetext{
${ }^{85}$ Rabben, supra, note 5 at 45 .

86 The following question was asked at a Parliamentary Committee meeting; As parliamentarians we sometimes have a dual role, one being to safeguard the taxpayers' money and protect our borders, and the other as Canadians to be compassionate and humanitarian. Given that set of lenses, perhaps you can indicate to us how you would see the right balance being struck between those two ideals.

House of Commons, Standing Committee on Citizenship and Immigration, $1^{\text {st }}$ Sess, $41^{\text {st }}$ Parl, Evidence of Meeting 34, May 1, 2012 at 1025 (The Hon Chungsen Leung). An excerpt from a Citizenship and Immigration Canada Guide states as follows:

Canada's humanitarian tradition of offering protection to displaced and persecuted people is known around the world. Each year, Canadians assist refugees and other persecuted people to rebuild their lives in Canada
}

Citizenship and Immigration Canada, "Guide 6000: Convention Refugees Abroad and Humanitarian-

Protected Persons”, online: http://www.cic.gc.ca/english/information/applications/guides/E16000TOC.asp. 
grant or deny asylum contextual, clear-headed and legally sound in order for the host community's interests in altruism, well-being and resource preservation all to be advanced.

There is some empirical research to support our purely contextual analysis of stakeholders' interests and values. For instance, as referred to earlier, the Canadian Council for Refugees (CCR) recently commissioned a report on how asylum seekers react to the asylum process. ${ }^{87}$ Consistent with our postulate that the legitimate asylum seeker's interest is primarily in receiving safe haven (i.e. being able to communicate need and receive an accurate and contextually sensitive decision), the study found that claimants' experiences of their hearings were dictated largely by the behaviour and attributes of the decision-maker assigned to their case. The claimants tended to have a positive experience when the decision maker was informed (knew the file, knew the country conditions), humane (made eye contact, recognized emotions), and non-interventionist in relation to how the claimants chose to present their claims (asked open-ended questions, did not interrupt, etc.). Conversely, claimants tended to have a negative experience when the decision maker displayed the opposite attributes. Again, this data generally supports the view that legitimate refugee claimants want to be able to tell their story and have their story heard, understood and appropriately acted upon-i.e. through the granting of asylum. Furthermore, as indicated earlier, many claimants also reported feelings of severe distress related to long processing times. ${ }^{88}$ In this way, the CCR study supports the proposition that accuracy, efficiency and juridical sensitivity to context in the asylum-granting process are important to genuine asylum seekers.

As for empirical evidence relating to the host community's interest in accuracy, efficiency and juridical sensitivity to context in the refugee status determination system, public opinion polls are instructive. In September, 2009 a Harris/Decima research survey of over 1000 Canadians contacted by telephone revealed that Canadians have a desire to help refugees, but at the same time are

\footnotetext{
${ }^{87}$ Canadian Council for Refugees, The Experience of Refugee Claimants, supra, note 70.

${ }^{88}$ Ibid, at 11.
} 
concerned with detecting fraudulent claims as well as saving time and money. ${ }^{89}$

Accuracy and sound judgment in decision making could help achieve the first two goals, and an efficient process could help achieve the others.

\subsection{Conclusion}

In the final analysis, our examination of dysfunctional elements within Canada's refugee status determination system has revealed the underlying stakeholder interests in the asylum process. An examination of these underlying interests in turn revealed that accuracy, efficiency and juridical sensitivity to context could be suitable pillars for reform of the refugee status determination system. In particular, viewing refugee status determination as a discursive process reinforced the position that any reform initiatives undertaken should ensure that that the adjudicative model better conforms to the peculiar contours of the experience of forced exile. Reform should therefore seek to transform both structures and approaches around asylum.

\footnotetext{
89 "Government Prepares for Public Relations War over Refugees", Embassy Magazine,(17 March, 2010); See also, "Refugee Rules Okay: report, Canadians hesitant to reform system", Montreal Gazette (27 November, 2010). According to the poll, only 30\% thought there were too many refugees in Canada; $64 \%$ agreed that asylum was part of Canada's humanitarian tradition. Only $21 \%$ agreed that the system does a good job of weeding out bogus claimants. Only $44 \%$ agreed that some refugee claimants are "queue jumpers". Only $44 \%$ also agreed that when processing times are too long, refugee claimants become a burden on taxpayers. $51 \%$ agreed that the existence of bogus claimants hurts genuine claimants. 58\% wanted unsuccessful claimants removed quickly. $84 \%$ thought reform of the refugee system was something to be explored, but not necessarily definitely needed; $81 \%$ wanted quicker processing times to ensure genuine refugees stayed and non-genuine ones were removed. Only $40 \%$ wanted to see processing differentiated based on country of origin whereas a majority (56\%) thought that all claimants should be treated the same. However, $66 \%$ were in favour of visa requirements to combat bogus claims. Incidentally, this research survey also supports our proposition that the government's views are not always synonymous with the views of the host community. The government had commissioned the survey in relation to a proposed reform. Despite the survey findings, the reforms that ended up being tabled contained very restrictive provisions - some of which were not even supported by a majority of those polled. For instance, the Protecting Canada's Immigration System Act( Bill C-31),supra note 1, provides differential treatment for claimants from designated "safe" countries of origin, despite the fact that $56 \%$ of those polled were not in favour of differential treatment on such a basis (see above). See also The German Marshall Fund of the United States, Transatlantic Trends; Immigration 2010 (February 4, 2011). This report showed that Canadians look more favourably on immigrants than Americans or Europeans.
} 
Chapter 3: Reform of Canada's refugee status determination system

\subsection{Introduction}

In the preceding sections we explored the nature of refugee status determination. We found that it was an adjudicative function that exists in multiple, and sometimes conflicting, contexts. It forces us to confront alterity. It has an anthropological basis and purpose. It touches on the psyche-fear, trauma, and liminality are all part of it. It has sociological, economic, political, cultural and human rights dimensions. Mostly it is about storytelling - in all senses of the word. We have also seen the ways in which refugee status determination, as currently carried out in Canada, is not entirely satisfactory. Those in need of help are not always identified, mistakes are not always corrected, the process is slow and complex and plagued by equivocation, distorted communication, lack of information and narrative overkill. Having looked at function and dysfunction, it is now time to look at reform. Inspired by academic thought, other asylum systems, and other successful Canadian adjudicative structures, we will make the case for structural and ideological reform of refugee status determination in Canada. $^{90}$

\footnotetext{
90 There have been several comprehensive reforms proposed by Canadian academics. The first was that of Rabbi Gunther Plaut in 1985 which, following the Supreme Court of Canada's decision in Singh v MEI, advocated a single oral hearing before a specialized quasi-judicial refugee tribunal followed by a right to judicial review at the Federal Court with leave. See W Gunther Plaut, Refugee determination in Canada; A report to the Honourable Flora Macdonald, Minister of Employment and Immigration (Canada: Minister of Supply and Services Canada, 1985). Plaut's recommendations were implemented in 1989 and the current IRB-centered system was created. In 1992 James Hathaway (supra, note 49) was commissioned by the IRB to study information gathering and suggestions of incompetence and bias. At the end of his report, Hathaway made over 30 recommendations for reform of refugee status determination in Canada. The Law Reform Commission of Canada also issued a report in 1992. See Law Reform Commission of Canada, The Determination of Refugee Status in Canada: A Review of the Procedure, Draft Final Report, March, 1992. Finally in 2009, Peter Showler produced a report entitled, Fair, Fast and Final (supra, note 71) which recommended speeding up processing time and adding an internal appeal layer to the process as well as dramatically increasing the number of Board members with legal training.
} 


\subsection{Other decision-making bodies and processes}

Before we suggest concrete reform proposals for discussion, we should spend some time looking at how well other similarly situated processes and decision-making bodies succeed in advancing stakeholder interests effectively. By doing so, we hope to gain valuable insight and inspiration for the task ahead and to be better able to imagine and describe asylum process structures and approaches that might be seen as more legitimate than those currently existing in Canada.

We will consider three bodies within three processes: the Administrative Tribunal of Quebec (administrative justice process), the Parole Board (the parole process) and the Tax Court of Canada (taxation appeal process). The choice of these bodies for comparison purposes was informed by the sorts of arenas in which they operate. Like the IRB, all three bodies deal with subject matter that is high stakes, socially contentious and complex. For instance, the Tribunal administratif du Québec (TAQ) is a large tribunal which plays a decisive role in administrative justice in the province of Quebec. Its jurisdiction touches on core liberty and security of the person issues - everything from mental disorder (NCR verdicts, confinement in an institution), to healthcare entitlement, to educational rights, to denial of social assistance benefits, etc. Many litigants are marginalized by poverty or mental illness and members must have a good working knowledge of some 60 different pieces of legislation, Parole decisions affect individual liberty interests as well as collective well-being and require analysis of complex psychological and sociological data in the context of the marginalized prison population. The Tax Court resolves complaints from taxpayers as against taxes levied by the Canada Revenue Agency and in doing so must deal with the notorious complexity of tax law. While there is no significant liberty interest at stake in these cases, taxation does touch on the issue of social equality; for, as pooled resources shrink in the traditional Western welfare state, it is important that taxation policy be seen as fair. We will briefly examine the extent to which these tribunals and processes are successful in advancing the interests of stakeholders and attempt to identify their positive characteristics, with the goal of 
importing some of these characteristics into a vision of a reformed refugee status determination system.

\subsubsection{TAQ/administrative justice process}

The TAQ is a quasi-judicial mega-tribunal created as an amalgamation of several smaller administrative tribunals. In 2010-2011 the TAQ had some 20,000 cases in inventory. ${ }^{91}$ There are 81 full time administrative judges and 30 part time administrative judges. Its annual budget in 2010-2011 was over 32 million dollars. The TAQ was recently recognized as possessing many of the attributes of a court of law and as fulfilling an important role in Quebec society. ${ }^{92}$ Hearings before the TAQ are fully adversarial, but many litigants are unrepresented due to poverty. TAQ has developed its own jurisprudence, which is frequently cited internally. ${ }^{93}$

In terms of stakeholder satisfaction at the TAQ, we begin by examining the level of complaint. There has been very little scholarly material produced with regard to the TAQ as an institution. ${ }^{94}$ There appear to be few major complaints about individual decisions voiced in the news media. ${ }^{95}$ Lawyers appearing before the TAQ indicate a general level of satisfaction, describing the procedure as relatively efficient and the decision makers as generally neutral and patient. One lawyer who had experience with both tribunals, described the atmosphere at the TAQ as being much less emotional than that at the IRB. ${ }^{96} \mathrm{~A}$ survey done by the TAQ with respect to the satisfaction level of unrepresented

\footnotetext{
${ }^{91}$ Tribunal administratif du Quebec, 2010-2011 Annual Report (Quebec: Tribunal administratif du Quebec, 2012) at 1-2.

92 The Bastarache Report states that « Le TAQ possède plusieurs des attributs d'une cour de justice et ses fonctions sont importantes pour la société québécoise23 » Michel Bastarache, Commission d'enquête sur le processus de nomination des juges du Québec: synthèse (Quebec: Les Publications du Québec, 2011) at 20.

${ }_{93}^{93}$ For instance, see MB c Quebec (Emploi et Solidarité) 2001 CanLII 37053 (QC TAQ)

${ }^{94}$ We found two items: Suzanne Comtois, "Le Tribunal Administratif du Québec: Un Tribunal Suffisamment Indépendent?" (2000-2001) 14 Can J Admin L \& Prac 127 and Jêrome Garant, "Le Tribunal Administratif du Québec : La Procédure et La Preuve" (LLM Thesis, University of Laval Faculty of Law, 2004) [unpublished]

${ }^{95}$ A search of French media in Quebec using the search term "taq", brought up 131 news stories, none of them critical of a TAQ decision, although a few suggested that TAQ judges were not sufficiently independent.

${ }^{96}$ Interview with Me Richard Goldman (November 9, 2011).
} 
applicants was generally positive. ${ }^{97}$ Positive public comments made about the TAQ tend to center on panel composition (as we shall see below, at least one member must be a lawyer or notary) ${ }^{98}$ as well as concerns around fairness and accessibility. ${ }^{99}$ Thus, it is fairly safe to say that there is no hue and cry being raised against the TAQ, either in the public space or among the legal community. To the extent that the inference can validly be drawn from a lack of complaints, it appears that stakeholders are being adequately served by the TAQ. Furthermore, the TAQ shows professionalism in part through the fact that it has developed its own jurisprudence. The question then becomes: to what characteristics is the relative "success" of the TAQ attributable?

The TAQ's rules as to the qualifications of its sitting members could provide answers. For instance, TAQ's enabling statute provides that:

40. In the social affairs division, at least 10 members shall be physicians, including at least four psychiatrists, at least two members shall be social workers and at least two other members shall be psychologists. ${ }^{100}$

Furthermore, in social assistance benefit cases, the panel must be composed of two members, one of whom must be a lawyer or a notary ${ }^{101}$. If the case involves a handicapped person, or relates to incapacity to work by reason of a disability, the other panel member must be a physician. ${ }^{102}$ Cases relating to confinement of mentally ill persons must be heard by a three-member panel composed of a lawyer or notary, a psychiatrist, and a social worker or a psychologist. ${ }^{103}$ Cases involving municipal taxation must be heard by a lawyer or notary and a chartered

\footnotetext{
${ }^{97}$ Leger \& Leger survey of satisfaction of unrepresented claimants at the TAQ, Tribunal Administratif du Quebec, online:

http://www.taq.gouv.qc.ca/documents/file/Rapport_d_analyse_sondage_fevrier_2007.pdf.

Nonetheless, processing times at the TAQ are not ideal: there is a two year wait for a hearing. See Tribunal Administratif du Quebec, Statistics, online: http:/www.taq.gouv.qc.ca/documents/file/TAQIM\%20Mars\%202011_STATOFF.pdf (statistics 2011).

${ }^{98}$ Lise I. Beaudoin, «Projet de loi 4 sur la justice administrative, La présence de juristes sur les banc doit être maintenue » Journal du Barreau, 35:16 (2003).

${ }^{99}$ Garant, supra, note 94, at 121-125.

${ }^{100}$ Administrative Justice Act, RSQ c J-3, s. 40.

${ }^{101}$ Ibid, s. 21. Notaries in Quebec attend law school and have law degrees.

102 Ibid

${ }^{103}$ Ibid s. 22.1
} 
appraiser ${ }^{104}$, and the rules go on in this vein. ${ }^{105}$ What we can clearly observe is that the qualifications of the decision-maker are tailored to the subject matter of the case. The legislative goal appears to be to have cases heard by specialized, expert decision-makers - and all panels must include at least one lawyer. ${ }^{106}$ There is some evidence that it is, in fact, these legislated member qualifications that are viewed as key to the success of TAQ and Quebec's administrative justice process in general. In 2003, the Barreau du Quebec testified before a parliamentary commission in opposition to proposed changes to the TAQ's enabling statute that would have modified the general rule that all TAQ panels be composed of at least one lawyer or notary. The Barreau stated that: "les bancs formés d'un avocat ou d'un notaire apportent les garanties de compétence et de crédibilité que les citoyens attendent des personnes appelées à décider de leur droits..." The Barreau's concerns centered on the notion that only legally trained persons could guarantee the quality of decision-making necessary to safeguard the rights of individual litigants challenging state action and to give legitimacy to the administrative justice process. ${ }^{107}$ As explored above, legitimacy flowing from qualified decision-makers is what is lacking in the IRB, and by extension the entire refugee status determination process. In this way, the TAQ's legislated member qualifications could serve as a model for reform of decision-making in the asylum context.

\subsubsection{Parole Board/parole process}

The parole process begins with a non-adversarial hearing before a twomember panel of the Parole Board of Canada. The primary role of the Board is to determine risk of recidivism, but the Board also takes victim impact into account. Decisions denying parole may be appealed to the Appeal Division of the Board, whose decision may then be judicially reviewed by the Federal Court of Appeal.

\footnotetext{
${ }^{104}$ Ibid s.33

105 Ibid s.23-37.

106 There is only one exception: see Administrative Justice Act, supra, note 100, section 33 (municipal taxation, low-value property)

${ }^{107}$ Beaudoin, supra, note 98 . The amendment was never made.
} 
In 2009-2010 the Board conducted almost 17,000 parole hearings. ${ }^{108}$ The Board has some 80 full or part-time members. Its annual budget for 2011 was 51 million dollars. Members are political appointees who must have the following qualifications:

- A degree from a recognized university in one of the disciplines comprising the human sciences (law, criminology, social work, psychology, sociology, etc.) or an acceptable combination of relevant education, job-related training and/or experience.

- A minimum of 5 years experience in a decision-making environment and/or in the interpretation or application of legislation, government policies or directives.

- Knowledge of the criminal justice system; Knowledge of the societal issues impacting on the criminal justice environment including gender, Aboriginal and visible minority issues; ${ }^{109}$

These qualifications are not legislated, however. The only legislated qualification is that members reflect community diversity. ${ }^{110}$ Appeal Division members are chosen from among general members, and do not need to have any special qualifications. The Board's full parole grant rate is $41 \%$ and the day parole grant rate is $66 \%{ }^{111}$

The question of whether the Parole Board has established itself as a legitimate institution among stakeholders is a complex one. Among the general public, the name "Parole Board" tends to evoke a negative response based on an impression that the Board is too lenient in granting parole, placing the community at risk. However, a slightly more in-depth analysis reveals that stakeholder perception of the Parole Board is nuanced and may be improving over time. In terms of the public space, the Wikipedia entry on the Parole Board lists 12 controversial Parole Board decisions involving violent crimes committed by

\footnotetext{
108 Parole Board of Canada, Performance Report 2009-2010 (Ottawa: Parole Board of Canada, 2011).

${ }^{109}$ Parole Board of Canada, Employment, online: http://pbc-clcc.gc.ca/employ/gicqualeng.shtml\#3

${ }^{110}$ Corrections and Conditional Release Act, SC 1992 C 20, s. 105 (1)

111 Parole Board of Canada, Fact Sheet, PBC QuickStats, online: http://pbcclcc.gc.ca/infocntr/factsh/parole_stats-eng.shtml
} 
parolees. ${ }^{112}$ A television news report in 2003 indicated that police were highly critical of Parole Board decisions, and that many dangerous offenders were unaccounted for. ${ }^{113}$ The Canadian Police Association told the press in 2003 that 66 people had been killed by parolees in the previous five years. ${ }^{114}$ But a current search of the phrase "parole board" on the websites of both major Canadian national newspapers turned up eleven articles that could be interpreted as being critical of specific Parole Board decisions or the parole process in 2009, 2010 and 2011 out of almost 1200 results. $^{115}$ An extensive victims' survey was conducted by the Parole Board with the result that $74 \%$ of respondents reported that they were very satisfied or satisfied with their overall experience at the Board, although the majority still felt that victims had less rights than offenders. ${ }^{116}$ A citizen's forum at the Parole Board was conducted in 2001. Many citizens reported having a negative perception of the Board and the competency of Board members until selection criteria were explained and they participated in a mock parole hearing where they were required to render a decision on a case study. ${ }^{117} \mathrm{It}$

\footnotetext{
${ }^{112}$ Wikipedia, online: http://en.wikipedia.org/wiki/Parole_Board_of_Canada\#Criticism_and_controversy.

113 "Easy Out: Catching those on the lam" (April 22, 2003), CTV News online: http://www.ctv.ca/CTVNews/WFive/20030422/WFIVE_rope_parole_030425/

${ }^{114}$ ibid

115 "Robert Latimer Granted Full Parole" (November 19, 2010) The Globe and Mail; "Parole Hearing a soapbox for Clifford Olson"(November 29, 2010) The Globe and Mail; "Former Cop who attacked 8 women granted parole after 4 years in prison" (October 4, 2010) The Globe and Mail; "Family of slain officer demands parole changes"(April 14, 2010) The Globe and Mail; "Psychopaths Charming their way of out prison" (February 4, 2009) The National Post; "Sympathy for murderers, but not the murdered"(April 23, 2010) The National Post; "Child Killer earns more freedom" (June 30, 2011), The National Post; "When death is the only escape"(July 16, 2011) The National Post - here the Parole Board is criticized for not releasing a terminally ill inmate; "Hurt town stunned again" (September 9, 2011) The National Post; "How to fix the parole system" (September 13, 2011) The National Post; "Toronto 18 member released"(October 3, 2011) The National Post. For comparison purposes, a similar search over the same time period using the search term "immigration and refugee board" turned up 45 results and some 22 were critical of the IRB or the asylum process in some way.

${ }^{116}$ Parole Board of Canada, Research Report "2009 Victim Questionnaire Results", (Ottawa: Parole Board of Canada, 2010), online: http://pbc-clcc.gc.ca/rprts/quest/quest09-eng.pdf.

${ }^{117}$ Parole Board of Canada; "Parole and Public Safety: a public forum, Final Report" (Ottawa: Parole Board of Canada, 2001), online: http://pbc-clcc.gc.ca/rprts/ccjareport-eng.shtml\#4.
} 
is not easy to find instances where other stakeholder representatives (the police, for instance) have been particularly critical of the Parole Board or the parole system in recent years. There is also little or no evidence of dissatisfaction with error correction, and this is not surprising since, as noted above, unlike the asylum process, parole board decisions are subject to two levels of review or appeal as of right —one of which involves the federal appellate judiciary.

We have seen the plethora of criticism levelled at the IRB and the refugee status determination system in the scholarly literature; in the case of the Parole Board, there has been much less written, and much of it is not particularly critical of the Parole Board or the parole process per se. Most of what is written by lawyers or legal scholars focuses on procedural safeguards at parole hearings or the process of the process of risk assessment without being overtly critical or calling for systemic reform. ${ }^{118}$ The IRB, conversely, suffers criticism from both insiders and outsiders: from the ordinary sensibility of media and the general public, as well as the more informed sensibility of lawyers and government.

Overall, these explorations show that the Parole Board and the entire parole process, although subject to negative impressions in the public space and a difficult and highly politically charged context, is not facing a crisis of legitimation today. Again, as in the case of the TAQ, it could be argued that the parole process' relative success may be attributable to selection criteria for Parole Board members that are rationally connected to the issues involved in parole. Requiring a university degree in areas such as law, criminology, psychology or sociology, plus experience interpreting or applying legal provisions, enhances the chances of accurate decision-making in the context of assessing risk of recidivism. Furthermore, the Parole Board seems to take an active role in its own legitimation. It reaches out to stakeholders (victims, the general public) to try to erase negative stereotypes about incompetency and callousness by imparting accurate information. One particularly useful tool in this regard is a page on the

\footnotetext{
${ }^{118}$ A worthwhile book on the Parole Board in the 1980s is A Rock and Hard Place, written by a former Board member. The author states that the ratio of competent members to non-competent members was 4 or 5 to 1 at the time she served. See Lisa Hobbs Birnie, A Rock and a Hard Place: Inside Canada's Parole Board (Toronto: Macmillan, 1990) at 209.
} 
Parole Board's website entitled "A Day in the Life of a Board Member" "119 which provides a glimpse into the Board's day to day work and precisely what goes into making a decision on parole. The victim survey and the citizen's forum (in particular the role-playing exercises) referred to earlier show both respect for and recognition of stakeholders' concerns. There is little indication that the IRB has conducted anything similar, although admittedly the public's need for reassurance about the work of the Parole Board is much more acute, given that public safety is directly involved.

\subsubsection{The Tax Court of Canada / taxation appeal process}

The Tax Court of Canada is a wholly judicial tribunal that sits in appeal of decisions of the Canada Revenue Agency. The Tax Court shares offices with the Federal Courts of Canada and, like those courts, conducts hearings in various locations. In $2010-2011$, it accounted for $37 \%$ of the workload ${ }^{120}$ of the Courts Administration Service ${ }^{121}$ which had annual expenditures of some 92 million dollars. ${ }^{122}$ Proceedings before the Tax Court are similar to trials and many taxpayers are unrepresented. The Tax Court is, accordingly, regularly required to assess the credibility of witnesses. Decisions of the Tax Court may be appealed as of right to the Federal Court of Appeal. There are presently 26 judges on the Tax Court, including supernumeraries. Qualifications are legislated in section 4 of the Tax Court of Canada Act (R.S.C. 1985 c.T-2) which reads as follows:

(3) Subject to subsection (4), any person may be appointed a judge of the Court who

(a) is or has been a judge of a superior court in Canada;

(b) is or has been a barrister or advocate of at least ten years standing at the bar of any province, or

(c) has, for an aggregate of at least ten years,

(i) been a barrister or advocate at the bar of any province, and

\footnotetext{
${ }^{119}$ Parole Board of Canada, “A Day in the Life of a Board Member”, online: http://pbcclcc.gc.ca/org/bmlife-eng.shtml.

${ }^{120}$ Based on recorded entries. See Courts Administration Service, Annual Report 2010-2011 (Ottawa: Courts Administration Service, 2012) at 21.

${ }^{121}$ Which administers the Federal Court of Appeal, the Federal Court, the Court martial Appeal Court, and the Tax Court.

122 Annual report 2010-2011, ibid note 120, at 27.
} 
(ii) after becoming a barrister or advocate at the bar of any province, exercised powers and performed duties and functions of a judicial nature on a full-time basis in respect of a position held pursuant to a law of Canada or a province

The Tax Court replaced the Tax Review Board in 1983. The following excerpt explains the reasons behind the creation of the Tax Court:

In his address to the $35^{\text {th }}$ Annual Tax Conference of the Canadian Tax Foundation, Mr. Alban Garon, Associate Deputy Minister of Justice stated that more than $30 \%$ of the taxpayers appearing before the Tax Review Board were unrepresented by a lawyer, accountant or other person familiar with the activities of the board as a tribunal independent of the government. In order to dispel any allegations that the board members were senior civil servants and that the board was a commission performing functions of the executive branch of the government in the income tax area, the status of the board was changed to that of court and its members to that of judges. In making this change, Mr. Garon pointed out that it was of equal importance to the government that the Tax Court continue to be a forum easily accessible to the taxpayer as was the experience before the Tax Review Board. ${ }^{123}$

Thus, the Tax Court was seen as the cure for the dysfunction and delegitimation of the Tax Review Board, an administrative tribunal. Although it is a superior court of record, the Tax Court's mantra has always been informality and accessibility. ${ }^{124}$ It has managed thereby to retain the best features of an administrative tribunal. In the fiscal year 2010-2011 its 26 judges disposed of almost 5000 cases. $^{125}$

Fortunately, for our purposes, there is little or no extrapolation needed to determine whether the Tax Court is a successful institution and whether it makes a positive contribution to the taxation appeal process: a recent article describes the Court in glowing terms:

The court has garnered respect from both the general public and the tax community. From the perspective of the general public, the accessible and flexible procedures available under the informal procedure allow for relatively straightforward appeals to be heard regardless of location or the amount at issue. At the same time, the general procedure permits more complex tax appeals to be determined in accordance with a formal process better suited to complex cases involving sophisticated taxpayers where the amounts at issue or the principles involved are significant.

\footnotetext{
${ }^{123}$ Ronald Appleby and A. Lorne Greenspoon, "The Tax Court of Canada and the Tax Appeal Process" (1984-1985) 5 Advoc Q 332 at 332.

${ }_{124}$ Annual Report 2010-2011, supra note 120 at 21.

125 Ibid at 28-29.
} 
Over time, the court has consistently demonstrated that it is a fair, neutral arbiter. The court's judges admirably navigate complex and often daunting provisions of various taxing statutes to ensure that justice is done....

Within the tax community, the court has been recognized for the superior quality of its judges and the decisions that they render. Judicial appointments to the court reflect its status as a prestigious institution and include private practitioners at the height of their practice.

In respect of its judgments, the court has been acknowledged for its role as the court of first instance that must deal with novel, difficult, and potentially farreaching cases, and its ability to arrive at the correct result in very challenging circumstances. In particular, the court has played a significant role in developing tax law. ...

The respect that the Tax Court commands in the community is deserved....The court is well positioned for a bright future. ${ }^{126}$

If only the same could be said of the IRB.

Indeed, the characteristics of the three bodies and processes we have just examined are significantly different from those of the IRB and the asylum process. All three successful bodies seem to be trying to ensure accurate and high quality decision-making through guarantees (some legislative) that member qualifications are rationally connected to the challenges posed by their caseloads-lawyers, doctors, psychologist and other professionals for the TAQ, criminologists for the Parole Board and "real" judges for the Tax Court. A reasonable effort is made to engage with stakeholders, and there seems to be a commitment to the law-making function, through development of jurisprudence. In short, these bodies strive, albeit in different measure, to achieve a true juristic culture. Error correction is assured through legislated reconsideration powers and/or appeal and judicial review as of right. There are few substantive ancillary proceedings that need to be filed, leaving the administrative justice, parole and

\footnotetext{
${ }^{126}$ Ian MacGregor, Thomas Akin, Jeff Oldewening and Kimberly Brown, The Development of the Tax Court of Canada: Status, Jurisdiction, and Stature, (2010) 58 Can Tax J (supp) 87 at 98-100. This assessment was echoed by Patrick Monahan: "The Tax Court of Canada has established a strong reputation in the tax community as an efficient, fair and independent adjudicator". See Patrick Monahan and Elie S Roth, Federal Regulation of Charities: A Critical Assessment of Recent Proposals for Legislative and Regulatory Reform Toronto: York, University, 2000) at 105.
} 
taxation appeal processes relatively simple (one question, one answer). There is no indication of significant levels of fraud, abuse or other "authenticity deficits". In short, these bodies and processes have many advantages that the IRB and the refugee status determination system do not. And that is unfortunate.

We do not pretend that the asylum process is the most important state function happening in Canada. Health care and the economy are major preoccupations both for the government and the governed. But at the same time, as we have seen, there is some indication that most Canadians see asylum as part of a humanitarian tradition that partially defines their country. Yet, asylum as an institution in Canada has been in state of general malaise for almost thirty years. Even if it might seem like a daunting task, we must continue to pursue sustainable reform. We actually have all the knowledge and tools at our disposal to do. Other systems work. The refugee status determination system can work also.

\subsection{Describing legitimate structures and approaches}

Extrapolating from voiced criticism of Canada's refugee status determination system, discourse analysis, and empirical evidence, we identified "accuracy", "efficiency" and "juridical sensitivity to context" as possible key values in an asylum process that would advance the interests of stakeholders effectively. How stakeholder interests in accuracy, efficiency and juridical sensitivity to context translate concretely into specific institutional structures and approaches is a complex question, but one that must be grappled with if a reform project is to be seriously pursued. For, in order for reform to be sustainable, it should strive to fulfill those stakeholder needs that have previously gone unmet.

We begin with the question of structures that would promote accuracy. We have suggested, first of all, that accuracy in asylum determination may be impaired if the refugee claimant is unable to communicate with the decisionmaker effectively through narrative. Specifically, we have seen that claimants (because of uncertainty, fear, trauma, culture shock, the limits of memory, and the belief that they must somehow reconstruct themselves) have difficulty producing 
an understandable, authentic and reliable narrative. Structures and approaches that would alleviate the distortion might be ones designed to reduce narrative and voice-over, eliminate the need for self-reconstruction, adjust for the psychological effects of forced exile, discourage monolog, and challenge the notion that truth is fixed. Secondly, we have suggested that accuracy in asylum adjudication also depends on undistorted reception of information. In order to achieve this, decision makers would ideally possess an open mindset, refrain from closing off avenues of inquiry, and be able to cope with complex legal and cultural data. Finally, we have argued that, in order for accuracy to carry the day, an effective error correction mechanism should be an integral part of the structure of the asylum process.

As for efficiency, a systemic structure that allows for a multiplicity of proceedings and steps should best be avoided. In short, the asylum process must be simplified. It stands to reason that, if the asylum seeker is asking one question ("May I stay?"), he or she should be given one answer. Thus, it would be simpler, for instance, if all possible grounds for allowing entry were dealt with in one consolidated proceeding before the same decision making body, followed by error correction. Ancillary and corollary proceedings (such as stay applications) should be discouraged — not by banning them, but by obviating or reducing the need for them by, for example, ensuring that all asylum processes have a suspensive effect on removal. This ideal of simplicity translates neatly into both economy and timeliness. The fewer structures and proceedings, the less cost involved. The more quickly the asylum seeker's case is resolved, the less likely he or she is to absorb scarce resources. And those structures and proceedings which are, in fact, essential, should be subject to controls with respect to their duration.

Finally, as for juridical sensitivity to context, this value might be promoted primarily through structures that ensure that decision-makers have and/or develop the necessary contextual and legal knowledge to apply to claimant-specific facts. Structures that might achieve this goal could relate to the selection process for decision-makers, context-specific and interdisciplinary training and sensitization 
programmes or anything else that would open up "critical spaces" within the site of initial determination - such as, for example, making the body a court of record with an expectation that a corpus of jurisprudence would be created.

These, then, are the broad outlines of possible structural and ideological criteria for a refugee status determination system that both advances the interests of stakeholders and conforms to the peculiarities of refugeehood and asylum as an institution. As we have tried to demonstrate, these criteria should not be seen as ones imposed from the "top down" based on an external ideal of what a refugee status determination system should look like. Rather, they could be interpreted as arising organically from stakeholder interests and the complex legal, political, anthropological, socio-economic and discursive characteristics of asylum and the asylum granting process. As such, it is reasonable to believe that changes based on these types of criteria would prove more sustainable and better-received than reform efforts have been in the past.

\subsection{Reform Proposals for Refugee Status Determination}

We suggest that it is high time to explore an alternative model for refugee status determination in Canada. A new structure could better reflect core stakeholder values of accuracy and efficiency. A new approach could better respond to the challenges inherent in refugee status determination. We will explore, on the structural level, the possibility of establishing a new initial asylum determination body, a new error correction mechanism, a simplified overall concept and a system of reasonable timelines. We will then turn to the question of whether, on the ideological level, we could improve decision-making, establish a new hearing room dynamic and adopt a more informed method of credibility assessment. We will present an outline of these specific new structures and approaches, explore their feasibility and examine how well they would advance stakeholders' legitimate interests. 


\subsubsection{Structural reform}

\subsubsection{Overview}

In terms of structural reform, we will explore the possibility of doing the following:

1) Creating a new site of initial determination by replacing the IRB either with a wholly judicial body (an Asylum Court modeled on the Tax Court) or a para-judicial Asylum Tribunal (modeled on the TAQ);

2) Simplifying the system through elimination of multiple recourses (PRRA, humanitarian and compassionate applications) by vesting the Asylum Court or Asylum Tribunal with jurisdiction to grant, not only refugee status and protected person status, but humanitarian asylum as well;

3)Creating a new error correction mechanism consisting of an appeal in writing as of right to the Federal Court of Appeal from decisions of the Asylum Court or Asylum Tribunal;

4) Legislating reasonable time lines with respect to initial determinations.

We will discuss each of the reform proposals in turn, focusing both on their feasibility and the ways in which they would advance stakeholders' interests in accuracy and efficiency.

\subsubsection{New site of initial determination: Asylum Court or Asylum Tribunal}

We suggest that it is time to consider moving away from an administrative or quasi-judicial model for refugee status determination and towards a whollyjudicial one. Refugees and host community alike strive for decisions that are fairer, more intelligent and more accurate. As James Hathaway suggested in 1992, a more juristic culture at the tribunal of first instance would be beneficial. ${ }^{127}$ One way to install a juristic culture would be to replace the Refugee Protection

\footnotetext{
${ }^{127}$ Hathaway: "Rebuilding Trust", supra, note 49, at 33.
} 
Division of the IRB (RPD) with a body similar to the Tax Court of Canada. ${ }^{128}$ We could call it the Asylum Court of Canada.

This is not a new idea; after an extensive study, the American Bar Association made essentially the same proposal in 2010 as a substitute for the poorly performing and non-independent Office of the Immigration Judge. The concept of a wholly judicial determination system was also recommended for further study by the Australian senate over ten years ago. The American Bar Association's decision to recommend moving towards a wholly judicial model was based on the following considerations:

Immigration judges already make decisions in cases or controversies involving individual rights and liberty - a job that is normally assigned to a formal court rather than an administrative agency.

Courts are experienced with providing judgments affecting unpopular or isolated minorities....

The existence of an Article I court (such as the US Tax Court, the Bankruptcy Court, etc.) may encourage a more uniform development and application of the law....

The Article I model is likely to be viewed as more independent than an agency because it would be a wholly judicial body, is likely, as such, to engender the greatest level of confidence in its results, can use its greater prestige to attract the best candidates for judgeships, and offers the best balance between independence and accountability to the political branches of the federal government. Given these advantages....the Article I Court model has been selected as the preferred option... ${ }^{129}$

The Australian senate's thinking on the issue was as follows:

Work should also be undertaken on the feasibility of a wholly judicial determination process. An objective of this would be to assess if such a process could be more open and transparent than the current multi-tiered system, which the majority of the Committee considers has been rightly criticized. ${ }^{130}$

\footnotetext{
${ }^{128}$ The appeal and adjudicative functions of the IRB in non-refugee immigration matters could remain within an administrative tribunal.

${ }_{129}$ American Bar Association. Reforming the Immigration System, supra, note 84 at 6-35, 6-36. The ABA favoured the Tax Court model over the idea of an independent administrative tribunal.

${ }^{130}$ Senate of Australia, A Sanctuary under Review: An Examination of Australia's Refugee and Humanitarian Processes, (Canberra: Senate of Australia, 2000) at 201. Conversely, in a comprehensive reform proposal put forward in the United States, author David Martin had this to say: "Almost no one believes feasible a system in which the courts make de novo determinations of asylum." See David Martin: "Reforming Asylum Adjudication: On Navigating the Coast of Bohemia" (1990) 138:5 U Pa L R 1247 at 1362.
} 
In practical terms, this vision of a wholly judicial site for refugee status determination would include the same sorts of structures for judge selection that exist in courts of law. In other words, the Asylum Court, like the Tax Court could be staffed by judicial appointees ("real judges"). In addition, these judges could have a specialized legal background appropriate to their decision-making function, just as the Tax Court judges do, as well as undergoing contextually appropriate training. Refugee status determination hearings could proceed before one judge and could continue to be informal and non-adversarial. The Asylum Court would be a true "federal" court in that it would have offices in all major cities of Canada, but whether it would be a "travelling" court, like the Federal Courts, would have to be determined.

Is there sufficient justification for the creation of an Asylum Court? As we have noted, refugee status determination is the one of the most complex adjudicative processes in the Canadian legal system. Common sense dictates that difficult decisions should be made by the best decision-makers. One might consider judges to be society's best decision makers; after all, decision-making is their profession. Consequently there is some force to argument that they would be ideally suited to tackle the inherent difficulty which asylum determinations present.

Nonetheless, some in the immigration and refugee bar might argue that any faith placed in the federal judiciary's ability and willingness to protect refugees is misplaced. In reality, though, there have been many key instances where the federal judiciary has proved instrumental in reining-in the political branch in asylum matters — not only in Canada, but internationally as well. ${ }^{131}$

\footnotetext{
131 Although sometimes on the wrong side of history, the Canadian Federal Courts have made some remarkably refugee-friendly decisions. See for instance, Kaur v MEI [1990] 2 FC 209 (FCA) - Court uses the Canadian Charter of Rights to allow battered woman to claim defense of duress in order to reopen inquiry and claim refugee status; Yusuf v MEI (1991) 133 NR 391Court scolds IRB member for sexist comments, declares such behaviour has no place in the justice system; Cheung v MCI (1993) 19 Imm LR 81 (FCA) - Court recognizes forced sterilization as a form of persecution; Farhadi v MCI (2000) 182 FTR 98 (FCA) - Court rules that a risk assessment conducted in accordance with the principles of fundamental justice is a condition precedent to a valid determination to remove an individual from Canada. In the so-called "trilogy" (Attakora v MEI (1989), 99 N.R. 168, Owusu-Ansah v MEI (1989) 8 Imm LR (2d) 212 and Armson v MEI (1989) 9 Imm LR(2d) 150), the Federal Court of Appeal attempted to put a
} 
Moreover, it could be also asserted that non-judicial decision-makers have more flexibility and subject-matter expertise than judges and are therefore better suited to administrative decision-making. That may well be the case in most areas of administrative law, but given its "life and death" nature, the asylum determination function is more akin to the reaching of a verdict in a criminal trial than to what we typically think of as administrative decision making — and most people would certainly balk at the idea of non-judges making decisions in the criminal sphere. Thus, it is the potential consequences to the individual subject to government action that should ideally inform the choice of decision-maker. Furthermore, as we will discuss below, the IRB itself does not even see itself as an expert tribunal $^{132}$ and the criteria for becoming a member demand little if any expertise in the usual sense whatsoever. The IRB is and was conceived as a lay tribunal and so the administrative law argument that it has more expertise than the courts is inherently problematic. But regardless of the theoretical debate around this issue, the fact remains that lay decision making has not proven entirely satisfactory in practice. Using judges for asylum determination is an idea that is worth exploring.

stop to irrational and arbitrary credibility assessment in refugee cases with lasting effect. In the United States, the Federal judiciary prohibited the government from instituting a "mass expedited asylum determination system" and encouraging mass arrivals to withdraw their claims(see Haitian Refugee Center $v$ Smith 676 F $2 d 1023$ ( $5^{\text {th }}$ Cir, 1982) and Orantes-Hernandez v Meese 685 F Supp 1488 (CD Cal, 1988). More recently, scathing opinions by the Federal Circuit Courts of Appeal on the poor quality of initial asylum determinations have been credited with creating impetus for reform. (See Stacy Caplow, “After the Flood: The Legacy of the 'Surge' of Federal Immigration Appeals” (2012) 7:1 Nw J L \& Soc Pol'y 1.) In the United Kingdom, the High Court and the Court of Appeal forced the government to remove particular countries from its socalled "white list" of safe countries of origin. (See $R$ on the application of Javed and others $v$ Secretary of State for the Home Department and Another [2002] QB129 and $R$ on the application of Zakir Husan and the Secretary of State for the Home Department [2005] EWHC 189 (Admin)) and the House of Lords blocked the government from withdrawing state support from asylum seekers who had filed their claims late: see $R v$ Secretary of State for the Home Department ex parte Adam et al (2007) 1 All ER 951. In Australia, the federal courts initially attempted to restrain the government over the MV Tampa incident, and, after a ten-year struggle, dealt a death blow to the "Pacific Solution" once and for all. See Victoria Council for Civil Liberties Incorporated $v$ Min for Imm \& Multicultural Affairs (2001) 182 ALR 617 and Plaintiff M61/2010E v Commonwealth of Australia; Plaintiff M69 of 2010 v Commonwealth of Australia (2010) 274 ALR 14 (HC). On the issue of the role of judges and the rule of law in the asylum system generally see Colin Harvey, "Judging Asylum” in Prakash Shah, ed, The Challenge of Asylum to Legal Systems (London: Cavendish Publishing Limited, 2005) 169.

${ }^{132}$ Rousseau, Crepeau, Foxen \& Houle, "The Complexity of Determining Refugeehood", supra, note 11 at 117 . 
In terms of advancing stakeholder interests in accuracy and juridical sensitivity to context, it is reasonable to expect that placing asylum decisions in the hands of judges would result in improved interpretation and application of refugee law and stricter adherence to the common law rules around assessment of credibility and evidence. ${ }^{133}$ Moreover, the judiciary is an institution that is fully independent of government. The same cannot be said of bureaucrats, civil servants and even current IRB members - as long as their reappointment depends on the political branch. Thus, entrusting refugee status determination to "real judges" may help ensure that decisions are free of government influence, and, in that sense, more accurate, more sensitive to the context of forced exile and more objective and impartial. Independence in decision-making is particularly crucial in the asylum context: it serves to counter-balance the politically and emotionally charged atmosphere in which asylum decision-making takes place, and keeps the focus on refugee status determination as a vehicle for promoting individual human rights, rather than protecting political and cultural sovereignty.

There is also some reason to believe that adopting a wholly-judicial model for refugee status determination could also be more efficient. The model can be seen as simply an extension of the uniquely Canadian (and very sound) approach to refugee status determination - namely, to do it once and to do it well. A single wholly-judicial body of first instance could obviate the need for multi-tiered administrative tribunals, such the proposed RPD/RAD divisions of the $\operatorname{IRB}^{134}$ or the AIT and UTIAC in the U.K., ${ }^{135}$ or an agency/administrative tribunal tandem (as in the U.S., Australia, New Zealand and many European countries). ${ }^{136}$ One has to wonder why most systems bring out the high-powered decision-making talent only on appeal after the damage has (presumably) already been done. Why not use them at the first tier to make the initial determination? Furthermore, there are other ways in which using judges for the difficult task of refugee status determination makes the best use of resources. The Canadian public subsidizes

\footnotetext{
${ }^{133}$ The American Bar Association agrees. See American Bar Association: Reforming the Immigration System, supra, note 84 at 6-6.

${ }^{134}$ Supra, note 40.

135 Supra, note 41

136 Ibid
} 
Canadian law schools to train lawyers, who then enter the pool of potential judicial appointees. If there is a quality deficit in asylum decision-making, why not fill that gap with pre-existing talent the Canadian public has already paid to develop? Why spend time and money to train administrative tribunal members to perform one of the most difficult adjudicative tasks more "judicially" when we could just assign the task to judges and be done with it? Few would dispute the fact that the Canadian judiciary as a whole is a proven success as an institution. In contrast to the IRB, it is the subject of relatively few complaints, both formally (such as before the Canadian Judicial Council) and informally in the public space. $^{137}$

Could an Asylum Court deliver timely decisions? It could, if it had a sufficient number of judges, ${ }^{138}$ was able to set aside the same amount of hearing time as the IRB currently does ( 3 hours per case), and maintained the current expedited claims process designed to weed out the strongest claims and process them summarily. But what about costs? There is no doubt that creation of an Asylum Court would be an expensive proposition in the short term. Tax Court judges earn $\$ 288,000$ per year, as opposed to approximately $\$ 105,000$ to $\$ 124,000$ per year for current IRB members. ${ }^{139}$ But in the long term, the cost

\footnotetext{
${ }^{137}$ Studies have shown that the Canadian judiciary is respected. For instance, see Joseph F Fletcher and Paul Howe, Public Opinion and the Courts: Institute for Research on Public Policy (Montreal, May 2000). See also Canadian Forum on Civil Justice, Public Perceptions of the Role of the Judiciary (Edmonton: Canadian Forum on Civil Justice, University of Alberta, 2005). The Canadian Judicial Council has launched only nine investigations since 1990. See Canadian Judicial Council, Investigations, online: http://www.cjc-ccm.gc.ca

${ }^{138}$ An Asylum Court would have to be at least twice as large as the existing Tax Court. Assuming working conditions similar to those at the current IRB (i.e. 4 weeks vacation, one week off every third week for reasons-writing, 2 hearings per day, 3-4 days per week), each Asylum Court judge could be expected to finalize some 200 claims per year, requiring appointment of some 50 judges in order to finalize 10,000 claims per year-i.e. half the claims initiated annually. This projection represents almost a $100 \%$ increase in efficiency, as the current IRB members tend to finalize between 100-150 claims per year each on average. (This estimate is based on statistics provided to the Canadian Council for Refugees, not for publication). For comparison purposes, the 25 judges of the Tax Court made some 5,000 dispositions in 2010-2011. See Courts Administration Service, Annual Report 2010-2011, supra, note 120 at 22). The Ontario Court of Justice completed 41,000 criminal trials in 2008-2009 (there are over 200 judges at the Court, most of whom hear at least some criminal cases): see Ontario Courts of Justice, Annual Report 2008-2009 at 46 \& Appendix 3.

${ }^{139}$ See Government of Canada, Governor-in-Council Appointees, online: http://www.appointments.gc.ca. For Tax Court Judge salaries see: Office of the Commissioner for Federal Judicial Affairs Canada, Federal Judicial Appointments, online: http://www.fja-
} 
differential with the current system might not be that great, if multiple recourses were rendered unnecessary and the length of stay of unsuccessful claimants was reduced. ${ }^{140}$ As the ABA pointed out in its proposal, expenditures in one area could be offset by savings in others. ${ }^{141}$

Finally, in terms of feasibility, there is no question that it would be a challenge to fill the potentially high number of judicial positions ${ }^{142}$ that might be required for the new Asylum Court. There is also the possibility that the very fact of having to make so many appointments all at once might dilute the quality of the appointments. However, the senior immigration and refugee bar, as well as the Department of Justice, should provide a large enough candidate pool. In addition, with decreased workload in the Federal Court, it is not inconceivable that some existing Federal Court judges might be interested in "moving down" to the Asylum Court. The prospect of having asylum decision-makers appointed for life through the normal judicial appointment process is not necessarily a cause for concern-provided that the normal appointment process for federal judges is followed without interference from the Minister of Citizenship and Immigration. Although the Asylum Court might well need to be at least twice the size of the Tax Court or the Federal Court, it certainly would not be the largest in Canada, as some provincial courts have over 250 judges. ${ }^{143}$ As noted earlier, whether the Asylum Court would be a travelling court like the Federal Courts is a detail that would have to be addressed, but given its size, this would likely be too costly.

cmf.gc.ca/appointments-nominations. Currently, 150 IRB members cost between 16 and 19 millions dollars annually in salary. Having 50 Asylum Court judges with salaries at the same level as Tax Court judges would mean expending some 15 million dollars in salary annually. If 50 judges were not enough, and 100 were needed, then the expenditure would double to 30 million dollars annually.

${ }^{140} \mathrm{CIC}$ estimates some 10 million dollars annually is spent on PRRA and humanitarian with risk applications. See Citizenship and Immigration Canada: Formative Evaluation of the Pre-Removal Risk Assessment Programme, 2008, online:

http://www.cic.gc.ca/english/resources/evaluation/prra/index.asp. The Minister of Immigration has estimated that 165 billion is spent on social benefits for extended claimant stays. See "Refugee Crackdown Draws Fire" (February 17, 2012) Montreal Gazette.

${ }^{141}$ American Bar Association: Reforming the Immigration System, supra, note 84 at 6-34.

${ }^{142}$ See note 138 , supra.

${ }^{143}$ Ontario Courts of Justice, Annual Report 2008-2009, supra note, 138, appendix B, online: http://www.ontariocourts.ca/ocj/files/annualreport/ocj/2008-2009-EN.pdf. The Ontario Court of Justice has over 200 judges. 
It is also legitimate to question how well suited the courtroom atmosphere would be to refugee status determination and how well judges could relate to individual refugee claimants. However, as the ABA pointed out, judges are accustomed to making the types of decisions required by refugee status determination. They regularly deal with marginalized populations. ${ }^{144}$ They also are routinely required to assess the credibility of witness testimony - particularly in the criminal context, and more and more frequently in a cross-cultural context. Judges have shown adaptability to culturally appropriate forms of dispute resolution. ${ }^{145}$ More and more deal with mediation. They undergo sensitivity training. There are specialized youth and family courts with adapted procedures. ${ }^{146}$ As we have seen, the Tax Court itself has a proven ability to relate to individual litigants: it has reduced formality, adapts to unrepresented litigants and does not seem to have difficulty assessing the credibility of the individual taxpayers who testify before it. There is no doubt that the Asylum Court would be a very unique court-almost a hybrid between a court and an administrative tribunal-but that, in many ways, is what the Tax Court and the provincial family and youth courts already are. Furthermore, Asylum Court judges would most probably need to have special domain-appropriate skills over and above those that qualify them as judges, thus enhancing their suitability for the task of refugee status determination.

In short, while there certainly would be challenges inherent in establishing an Asylum Court modeled on the Tax Court of Canada, they are not so insurmountable that the idea is not worthy of further research.

Another, but far less radical, alternative to a wholly-judicial model for the initial determination, would be a "para-judicial" one. ${ }^{147}$ This change would see the RPD replaced by a new administrative tribunal (we could call it the Asylum

\footnotetext{
${ }^{144}$ American Bar Association, Reforming the Immigration System, supra, note 84 at 6-35.

${ }^{145}$ See $R v$ Moses 71 C.C.C. (3d) 347 where a sentencing circle was employed by a Yukon judge for the first time.

${ }^{146}$ For instance the Court of Quebec has a special Youth Division and Ontario has special family divisions within the court system. The Ontario family court judges take an active role in the establishment of special procedures for family law cases. See Ontario Courts of Justice Annual Report 2008-2009, supra, note 138 at 52ff.

147 "Para-judicial" is distinct from "quasi-judicial".
} 
Tribunal of Canada) where each hearing would be presided over by at least one legally-trained decision maker-similar to the situation that exists at the TAQ. As we have seen, many other asylum systems make use of para-judicial modelsalthough for appeal and not for initial determination. ${ }^{148}$ In addition, the parajudicial model, since it retains the flexibility of an administrative tribunal, could also have space for an interdisciplinary element: as with the TAQ, decision making responsibility could be shared between lawyers and other appropriate professionals, such as psychologists or anthropologists. ${ }^{149}$

Like a wholly-judicial model, a para-judicial model would also have certain benefits in terms of accuracy and juridical sensitivity to context. ${ }^{150}$ Staffing an Asylum Tribunal exclusively with lawyers would certainly help achieve the aforementioned values for the same reasons an Asylum Court would, although it should be recalled that not all lawyers have the qualities necessary to become judges in terms of decision-making ability. Nonetheless, one distinct advantage that the para-judicial model may have over the wholly-judicial model in terms of accuracy and juridical sensitivity to context, is the aforementioned possibility of interdisciplinarity as advocated by Rousseau, Crépeau, Foxen and Houle. ${ }^{151}$ Not being subject to the constraints of the judicial appointment process, a para-judicial model could still bring legal expertise to refugee status determination, but augment it with other appropriate forms of expertise as well. Since refugee status determination (particularly with respect to credibility assessment) has cultural, psychological and sociological dimensions, expertise in these areas might well enhance accuracy and juridical sensitivity to context as much as involving the judiciary would. One of the keys to both accuracy and juridical sensitivity to context would seem to be intelligence and professionalism in decision making; a para-judicial model could achieve these, but in a different manner than a wholly judicial model.

\footnotetext{
148 University of Ottawa, Refugee Forum, Other Asylum Systems, supra, note 41.

${ }^{149}$ See Rousseau et al, "The Complexity of Determining Refugeehood”, supra, note 11.

${ }^{150}$ See comments in Showler, Fair Fast and Final, supra, note 71 at 14. See also Martin, note 130 supra at 1358 .

${ }^{151}$ Rousseau, et al, "The Complexity of Determining Refugeehood", supra, notes 11 and 149.
} 
Nonetheless, the question of independence in decision making also figures into the equation. "Real" judges are notionally independent since they enjoy security of tenure. This would not necessarily be the case for decision makers on a para-judicial board, however-raising the spectre of inappropriate influences being brought to bear on individual decisions. For instance, despite being quite successful, the TAQ still struggles with this problem. ${ }^{152}$ The concern can be overcome, but probably only with almost judge-like rules about the appointment and reappointment process for board members - i.e. a commitment to true "parajudiciality". In order to ensure compliance, these rules would likely have to be legislated, and not left to the government to implement. The qualifications necessary for Asylum Tribunal members would also likely have to be legislatedas is the case with the TAQ and New Zealand's Immigration and Protection Tribunal (IPT). ${ }^{153}$ At minimum, the qualifications would most likely have to be set to at least the standard of those of the Parole Board: an advanced degree in law and/or other appropriate fields, plus suitability to decision-making in the asylum context.

In terms of efficiency, it could be argued that creating a para-judicial board would, if subject to legislated rules as to the quality of decision-makers, be making good use of resources already expended on the training of lawyers and other professionals. As well, there would be adherence to the principle of using the best and brightest to make the most complex decisions, although perhaps not to the same extent as a wholly-judicial model. In terms of timeliness of decision making, an Asylum Tribunal would likely function at no worse a level than the current RPD, if all members were lawyers and all cases were heard by onemember panels. If interdisciplinarity were added to the decision-making landscape, however, panels would necessarily be composed of more than one member-i.e. a lawyer and at least one other professional, as is the case at the

\footnotetext{
${ }^{152}$ See notes 94 and 95 , supra.

${ }^{153}$ The qualifications of the members of this tribunal are statutorily mandated under section 219 of New Zealand's Immigration Act 2009-namely, a chair who is a District Court Judge, other members appointed by the Governor-General who are lawyers having held a practicing certificate for at least five years, and a representative of the UNHCR. Former refugee and protection officers, immigration officers or visa officers are not allowed to be members of the tribunal. See University of Ottawa, Refugee Forum, Other Asylum Systems, supra, note 41.
} 
TAQ. Cases would then take longer to come for hearing - unless the size of the Board were doubled or tripled. Interdisciplinarity could therefore entail either increased delays or increased costs, and thus more research would be needed to determine viability. In terms of economy, a para-judicial model would likely be much less expensive to set up in the short term than an Asylum Court, while still theoretically retaining the same cost advantages of the Asylum Court in the long term. In order to create the Asylum Tribunal, the RPD could essentially be reconfigured and re-populated, pursuant to a few relatively simple legislative changes. ${ }^{154}$ Nonetheless, the success of the para-judicial model is contingent on many external factors. The Canadian judiciary is more or less a known quantity in terms of functioning; the group of decision-makers inhabiting the para-judicial model would not be.

\subsubsection{System Simplification (elimination of multiple recourses/consolidation of protection grounds)}

The system being explored in this thesis would see an "all-in-one" approach to refugee status determination being implemented in Canada. We suggest that the first instance decision-making body (either the Asylum Court or the Asylum Tribunal) deal not only with the question of Convention refugee status, but with other forms of subsidiary protection as well. These could include existing "protected person status" under section 97 of the IRPA (currently conferred by the PRRA process after denial by the IRB), as well as the possibility of a new "humanitarian asylum" category designed to cover difficulty with return to country of origin that fell short of the other protection grounds. It might then be the case that it would no longer be necessary to make the PRRA and humanitarian processes available to most asylum claimants, thereby avoiding a multiplicity of proceedings, determinations and court applications. In fact, as alluded to earlier, recent Canadian reforms seek to do just this; they restrict access to PRRA and humanitarian applications for the most part to only those claimants

\footnotetext{
${ }^{154}$ I.e. legislating rules as to member qualifications and/or panel composition as Quebec's Administrative Justice Act does for the TAQ. See note 100ff, supra.
} 
whose claims have been denied in the distant past, and in this respect the reforms are quite sensible. Nonetheless, the all-in-one approach suggested here could only work if the asylum process as a whole unfolds rapidly. The more time that elapses between denial of status (be it Convention refugee status, protected person status or humanitarian asylum) and removal, the greater the chance of a change of circumstances or a new risk development that might make removal contrary to Canada's international obligations.

It is reasonable to believe that having the same decision maker render a single decision on all possible grounds for protection would be more accurate and more contextually appropriate than having multiple decision-makers rendering multiple decisions in succession. The chances of accuracy, consistency and sensitivity to the context of forced exile may well be higher where there is a thorough presentation of the facts as they may relate to all possible grounds of protection before the same high-quality decision-maker. Of course, an all-in-one system would deny claimants additional "kicks at the can", so to speak. However, if the initial asylum determination becomes more accurate and juridically sensitive (and there is an effective correction mechanism for those errors that do occur, as we will discuss shortly), then the absence of additional and separate routes of redress might become considerably less significant. The guiding principal would be something like: "Put all your eggs in one basket—and watch the basket." 155 As well, consolidating the protection grounds in one proceeding might contribute to reducing what we have termed the "authenticity deficit". If claimants arrived knowing that there were several grounds for asylum, they might be less inclined to try to fabricate stories designed to fit into a particular mold. This could be particularly true where one of the protection grounds was the proposed new category of "humanitarian asylum", which might have a sort of safety-net function.

As for the question of efficiency, it would seem simpler, quicker and more cost effective to resolve all issues with respect to an asylum claim at one time and in one place - rather than allowing for multiple successive proceedings

\footnotetext{
${ }^{155}$ Maxim attributed to Andrew Carnegie, How to Succeed in Life, 1910.
} 
as is now the case. This is the "one question/one answer" model alluded to earlier. The asylum seeker wants to know if he or she can join the host community group, and the host community must respond yes or no. By extension, consolidation of protection grounds in one proceeding might do the same thing for an error correction mechanism: if all grounds are canvassed at the initial hearing, all grounds will be verified on appeal. The cost-savings could arguably be fairly substantial.

There may be, nonetheless, some serious questions about the feasibility of the consolidated protection grounds model, particularly with respect to inclusion of a "humanitarian asylum" ground. There could be concerns that having to address three grounds of protection in one hearing would lengthen the hearings considerably. ${ }^{156}$ This outcome does not appear inevitable, however. The amount of extra time humanitarian jurisdiction would entail would simply depend on the scope of this recourse-i.e. whether humanitarian asylum could be granted on essentially the same set of facts as the other grounds of protection. ${ }^{157}$ Another issue that needs to be addressed, as alluded to earlier, is the fact that eliminating the separate PRRA and/ or humanitarian processes leaves no clear way of dealing with new facts or circumstances that may arise after the initial refusal of refugee status, but before removal takes place The possibility of some sort of reopening

\footnotetext{
${ }^{156}$ The idea of humanitarian jurisdiction was considered by Peter Showler in Fair Fast and Final, supra, note 41 at 17, but no recommendation was made. In contrast Joseph Rose advocated in favour of such a jurisdiction in the American context: See Joseph Rose, "The Asylum Seeker: The Proverbial Rat in the Evidentiary Maze of Asylum Law? Some Suggestions for Reform" (19941995) 24 Sw UL Rev 473 at 499.

${ }^{157}$ A consolidated grounds approach which includes humanitarian factors appears to be functional in Finland and is part of a reform package in the Netherlands. For instance, in Finland, claimants are interviewed by the police and then by an immigration officer who determines whether they qualify for a variety of types of residence permits. These permits can be based on international protection (refugee status), subsidiary protection (capital punishment, torture, cruel and unusual treatment), humanitarian protection (environmental disaster, armed conflict, insecurity, troubled human rights situation) or protection on other grounds (health, ties to Finland, other humane reasons). In the Netherlands, asylum would be granted on the basis of the refugee Convention, article 3 of the ECHR, humanitarian grounds related to conditions in the country of origin, indiscriminate violence or large scale human rights crises or family unity. While Finland's humanitarian provisions may be overly broad in scope in that they involve a different set of facts than those relating to refugee status (i.e. issues of health, environmental disaster and ties to the host country), the Netherlands' provision is theoretically a feasible model in terms of the factual elements that need to be examined. (University of Ottawa, Refugee Forum, Other Asylum Systems, supra, note 41).
} 
mechanism may therefore have to be considered-perhaps similar to what exists in the United States. ${ }^{158}$ Needless to say, this reopening mechanism must be designed in such a way as to avoid creating a new morass of legal procedures; perhaps reopening could be limited to changes of conditions in the country of origin or highly material and credible new evidence. As stated earlier, processing claims rapidly could also reduce the possibility of reopening becoming necessary - as would ensuring accurate determinations in the first place. ${ }^{159}$

\subsubsection{New error correction mechanism:}

In order to improve the ability of the refugee status determination system to correct errors in the initial determination, we have suggested that an appeal lie from a decision of the Asylum Court (or the Asylum Tribunal) to the Federal Court of Appeal as of right. We suggest exploring the possibility of appeals being decided, as a rule, on the basis of written materials only and by a panel of three judges of the Court of Appeal, as is currently the system in the United States. Under such a scheme, fairness would require that the appeal have a suspensive effect on removal and that the Court of Appeal issue written reasons for decision, particularly where the appeal is denied. As indicated earlier, all grounds for protection raised at first instance would be considered on appeal. As is currently the case for appeals under section 52 of the Federal Courts Act, the Court would ideally have the power to render the decision that the Asylum Court or Asylum Tribunal should have rendered in the first place - i.e. to grant or deny asylum. ${ }^{160}$

Would this mechanism contribute positively to accuracy, efficiency and juridical sensitivity to context in the asylum system as a whole? As we have seen, the complaints around error correction under the current system center on a lack of effectiveness - which also compounds any lack of accuracy or juridical sensitivity to context that may exist in the tribunals below. In contrast to the

\footnotetext{
${ }^{158}$ In the United States there is a right to apply to reopen a BIA appeal in limited circumstances, 8 CFR 1003,2(a), 1003.23(b)(1).

${ }^{159}$ As a last resort, claimants whose circumstances have suddenly changed dramatically could always apply to the Federal Court for some form of injunctive relief.

${ }^{160}$ Recent reforms in Belgium institute such a power for the CCE (Alien's Litigation Council) which sits in appeal of the first level administrative decision). See University of Ottawa, Refugee Forum, Other Asylum Systems, supra, note 41.
} 
current system, the error correction mechanism we have proposed for discussion responds squarely to the concerns of stakeholders in several ways. First, the remedy at the Federal Court of Appeal would be conceived as a true appeal governed by section 52 (c) of the Federal Courts Act, not judicial review. That is, the Federal Court of Appeal would be making a determination of the correctness of asylum decision below and could therefore reverse it. This is the same error correction mechanism that exists currently for Tax Court. ${ }^{161}$ Furthermore, the mechanism would not be subject to a leave requirement: it would be an appeal as of right. Nonetheless, this cannot mean that every refused refugee claimant would be able to appear in person before the Federal Court of Appeal, as was the case prior to $1989 .{ }^{162}$ There are simply too many ${ }^{163}$ negative asylum decisions rendered annually for that to work. The trade-off would be that the appeal as of right would be an appeal that is (normally) disposed of in writing. As indicated above, this would be substantially the same form of redress which exists ostensibly without objection in the United States as between the BIA and the Circuit Courts. ${ }^{164}$ Thus, this proposed error correction mechanism might be viewed as more effective because - in contrast to the current system - it would be an appeal on the merits, it would be an appeal as of right and it would be an appeal conducted by appellate level judges - all of which would seem to be quite favourable conditions.

The case could also be made that the involvement of the Federal Court of Appeal in the refugee process would have the added advantage of encouraging more consistent development of the law. Under the current system, the Federal Court of Appeal rarely pronounces itself on issues of refugee law. As a result, the judges of the Federal Court, despite having to deal with thousands of cases every

\footnotetext{
${ }^{161}$ Federal Courts Act, RSC 1985 c F-7,ss.27 (1.1) to 27(1.4).

${ }^{162}$ Negative decisions of the IAB were reviewable by the Federal Court of Appeal under section 28 of the previous Federal Court Act. A direct appeal as of right to the Federal Court of Appeal from a refugee board was part of one of three models (Model A) presented in the 1985 Plaut report, supra, note 90 , but was not adopted.

${ }^{163}$ There were over 13, 000 negative decisions rendered by the IRB in 2010. Statistics courtesy of the Canadian Council for Refugees, not for publication.

${ }^{164}$ In its extensive study of reform of the immigration system, the ABA did not identify the written appeal as a problem. See American Bar Association, Reforming the Immigration System, supra, note 84 .
} 
year, are provided with little legal guidance, resulting in a plethora of contradictory decisions as well as continual re-litigation of the same issues. It is probably not a coincidence that the state of refugee law seemed much clearerand actually evolved - during the period when the Federal Court of Appeal was in charge of error correction in the asylum process. ${ }^{165}$ An appellate court sitting in a panel of three tends to generate more stable precedent than trial judges sitting alone.

In terms of efficiency, moving error correction to the Federal Court of Appeal could correct an imbalance in resource allocation. Despite having 13 judges, the Federal Court of Appeal disposed of only 565 cases in 2010-2011. ${ }^{166}$ In contrast, the 25 Federal Court (trial level) judges disposed of 9,372 cases over the same time period - the majority of them concerning asylum seekers - either leave applications or reviews on the merits with an oral hearing. ${ }^{167}$ Moving the asylum cases to the Federal Court of Appeal would at least assure that the appellate judges' salaries were being more rationally expended. Another efficiency advantage of using the Federal Court of Appeal for error correction would be its aforementioned power, as an appellate level court, to render the decision that should have been rendered by the first-level tribunal in the first place. $^{168}$ In fact, between 1980 and 1993 (before judicial supervision of refugee status determination was transferred away from the Federal Court of Appeal to the Federal Court) the Court of Appeal fairly regularly either declared applicants to be Convention refugees or mandated this result on rehearing, even in credibility cases. $^{169}$ There does not seem to be any readily apparent reason why this practice

\footnotetext{
${ }^{165}$ A number of landmark decisions were rendered by the Federal Court of Appeal during this period: Attakora, supra, note 313; Adjei v MEI [1989] 132 NR 24; Salibian v MEI (1990) 113 NR 123;Ramirez v MEI (1992) 135 NR 390; Cheung, supra, note 131; Rasaratnam v MEI ([1992] 140 NR 138, et al..

${ }^{166}$ Courts Administration Service, Annual Report, 2010-2011, supra, note 120 at 22.

167 Ibid.

${ }^{168}$ Federal Courts Act, s. 52(c), supra, note 161. The U.S. Circuit Courts of Appeal can do this with respect to the BIA as well-either remand or reverse.

${ }^{169}$ Between 1984 and 1993 the Federal Court of Appeal declared the applicant before it to be a Convention refugee in the following cases: Dhillon v MEI (1990) 131 NR 62; Mahathmasseelan v MEI (1991) 137 NR 1; Hilo v. MEI (1991) 130 NR 236; Sabaratnam v MEI (1992) unreported, A-536-90; Ali v MEI (1992) unreported, A-236-91; Veeravagu v MEI A630-89 unreported; Wu v MEI (1992) (unreported) A-369-89; Addo v MEI (1992) 142 NR 170; Chen v MEI (1993)
} 
could not be revived - thus, eliminating the costs involved in rehearing the same claim twice. As well, having error correction done by the Court of Appeal would reduce one layer of process: currently the trajectory of a claim is IRB to Federal Court to Federal Court of Appeal (on serious questions of law). Under the proposed mechanism, the Federal Court would be by-passed. ${ }^{170}$

The question of whether the proposed error correction mechanism would be able to adhere to reasonable timelines is a difficult one. In order to find an answer it might be instructive to look at past and current judicial performance in similar contexts. Currently, leave applications at the Federal Court are disposed of in writing within 4 months before a single judge. ${ }^{171}$ For those cases which do receive leave and proceed to a merits review at an oral hearing, the time elapsed between the filing the originating document and the issuance of a reasoned decision on the merits of the judicial review is about 8 months. ${ }^{172}$ For Tax Court appeals to the Federal Court of Appeal, the total time elapsed appears to be around 9 months. ${ }^{173}$ Looking at the United States Circuit Courts of Appeal (by which the proposed error correction mechanism was inspired), however, we see significantly longer processing times. The median interval from filing to disposition in the Circuit courts for administrative cases (including immigration) from September 2010 to September 2011 was 16.3 months for all the Circuits. For the Ninth Circuit (which handles the greatest number of immigration cases),

\footnotetext{
unreported A-30-91; Cheung supra, note 131. In Surujpal v MEI (1985) 60 NR 73, Chaudri v MEI (1986) 69 NR 114 and Jocelyn v MEI (1991) 15 Imm. LR (2d) 272 the IRB was directed to find the applicant a Convention refugee on rehearing. In Attakora $v$ MCI, supra, note 131, a credibility case, the court stated: "I would allow the section 28 application, set aside the impugned decision and return the matter to the Board for redetermination on the basis that the applicant is a Convention refugee."

${ }^{170}$ Our suggested reforms would make no changes to the Federal Court's power to judicially review decisions of immigration officers and visa officers, or to issue injunctions or other prerogative writs.

${ }^{171}$ See Showler, Fair, Fast and Final, supra, note 71 at 8.

172 See, for example, Federal Court file IMM-3132-11: proceeding commenced May 11, 2011, leave granted September 19, 2011, oral hearing on December 15, 2011 and decision rendered with reasons on January 6, 2012.

${ }^{173}$ For instance in Tax Court file 2009-782 (a case of average complexity involving a taxi driver who was audited), the notice of appeal was filed on October 25, 2011 (Federal Court of Appeal file A-398-11) and the appeal was disposed of on July 26, 2012.
} 
the interval was 29 months. ${ }^{174}$ Nonetheless, these numbers might be skewed by the fact that the Circuit Courts of Appeals are dealing with significant backlogs caused by a huge spike in immigration appeals after $2002 .{ }^{175}$

What we might conclude from all this is that, although there may be a reason to be hopeful that our proposed error correction mechanism could adhere to reasonable timelines (4-9 months), there is a realistic possibility that the new mechanism could become a significant locus of delay within the system, thereby compromising efficiency. The risk of a major slowdown at the error correction stage might be mitigated if better initial determinations result in higher asylum grant rates and therefore fewer appeal files, and/or if a reduction in judicial workload follows a reduction in court proceedings filed in relation to applications for supplementary protection (i.e. appeals of PRRA and humanitarian refusals and applications for stays of removal). Also, increasing the number of judges from the current level ( 25 currently and 36 pursuant to reforms ${ }^{176}$ ) could go a long way to heading off delays as well. But, in the final analysis, even if there would be significantly longer processing times for error correction, it is at least arguable that they would be offset by time saved in the asylum system as a whole through the elimination of separate proceedings related to subsidiary protection. In other words, it would be the net result in terms of time savings that would be significant. As long as claims could be completely finalized faster than the current multiple recourse system (3-6 years), a case could be made that the proposed reform to error correction would enhance systemic efficiency.

Quite apart from, but still interrelated with, the issue of timeliness, there is the issue of feasibility. We need to explore whether it would be logistically possible for the Federal Court of Appeal to handle several thousand written refugee appeals annually. Again, there is considerable guesswork involved, but we do know that it did so between 1989 and 1993 without the system bogging

\footnotetext{
${ }^{174}$.See Administrative Office of the United States Courts, 2011 Annual Report of the Director: Judicial Business of the United States Courts. Washington, DC, 2012, at 87.

${ }^{175}$ See Caplow, supra, note 131.

${ }^{176}$ Balanced Refugee Reform Act, supra, note 1, section 41.
} 
down. ${ }^{177}$ In addition, the Federal Court does so now, as do the Circuit Courts of Appeals in the United States. ${ }^{178}$ Nonetheless, there is still the possibility, noted earlier in connection with processing times, that the number of appellate judges might need to be increased - or possibly a special division of the Federal Court of Appeal created in order for the proposed appeal mechanism to function smoothly. Would it be feasible for the Court of Appeal to review several thousand refugee appeals sitting in panels of three and to also provide written reasons? Again, the Circuit Courts in the United States do - and one might envision a system whereby a lead judge is assigned to each appeal, who, after receiving input from the rest of the panel, is then charged with producing written reasons that are adequate, but brief. ${ }^{179}$

What is proposed here is essentially a shift in the use of judicial resources-from triage of several thousand cases per year (leave applications) to merits review of the same cases (written appeals). While these might appear to be two quite different tasks from a judicial perspective, they are actually more similar than meets the eye. Reviewing a paper appeal and rendering a decision on the merits should not be a radically different experience for the judicial mind than reviewing an application for leave. A leave application is a complex document consisting of the IRB's reasons, an affidavit or a transcript, the evidentiary and documentary record before the IRB and a memorandum of fact and law. A paper appeal would involve essentially the same type of material (tribunal record and memoranda). In terms of the decisional process involved, instead of making a decision to grant or deny leave to proceed to an oral hearing on the merits as the Federal Court does, the Court of Appeal would use these written materials to

\footnotetext{
177 Greene and Shaffer, supra, note 66. In the course of conducting this study, the authors found that the 12 judges of the Federal Court of Appeal had disposed of 2000 leave applications in 1990 and the first quarter of 1991.

${ }^{178}$ The 25 judges of the Federal Court disposed of over 9,000 cases in 2010-2011, the majority of which were immigration cases, see notes 120 and 167 supra. Between March 2010 and March 2011, the 44 judges of the Ninth Circuit Court of Appeals disposed of some 4000 administrative appeals on the merits in 2010-2011(mostly in immigration cases mostly without oral hearing). See Administrative Office of the United States Courts, 2011 Annual Report, supra, note 173 at 92.

${ }^{179}$ For instance, on June 14, 2012 the Second Circuit disposed of a BIA appeal from a Mauritanian asylum applicant dealing with issues around credibility assessment and ineffective assistance of counsel in a two- page unpublished opinion. See Ba v Holder 2012 WL 2146323 (CA2).
} 
make a final determination instead. In other words, the result of the paper analysis would not be the granting of leave, but a decision to grant or deny the case on the merits. This would appear workable for the Court of Appeal, particularly if longer time periods were in play (as we have seen, the Court of Appeal can do a merits appeal of the Tax Court in 8 months). What is more, although the Federal Court judges are currently supposed to be performing a sort of triage to weed out frivolous or marginal cases that do not warrant an oral hearing, recent research suggests that they are actually already doing a merits review at the leave stage in any event. ${ }^{180}$ And all this in only four months time. Accordingly, there is some reason to be optimistic about the feasibility of having the Federal Court of Appeal perform error correction in the manner outlined above.

\subsubsection{Reasonable Timelines}

A lengthy refugee status determination process benefits no one. Ideally, then, there need to be maximum processing times established for initial determination and error correction and these times should be enshrined in legislation to help ensure enforceability. ${ }^{181}$ Nonetheless, a refugee claim is a complex, high-stakes procedure and accuracy and soundness of judgment might be compromised by attempting to conduct proceedings too quickly. Reasonable processing times might be 6 to 9 months for the initial determination and 6 to 9 months for error correction-12 to 18 months in total. ${ }^{182}$

A 6 to 9 month maximum processing time would seem feasible for initial determinations based on past experience and on the Board's own estimates. ${ }^{183}$

\footnotetext{
${ }^{180}$ Sean Rehaag, The Luck of the Draw?, supra, note 37 at 15.

${ }^{181}$ In this respect the Canadian government's 2010-2012 reforms are positive. Processing times will be established by regulation. See Protecting Canada's Immigration System Act, (Bill C3),,supra, note 1, section 59 and Balanced Refugee Reform Act, supra, note 1, section 13 (1)

${ }_{182}$ Peter Showler advocates a total processing time of 13 months. Showler, Fair, Fast and Final, supra, note 71 at 20.

${ }^{183}$ The IRB was able to process claims within 7 months in 1993-1994 and finalized some 24,000 claims in that period. Immigration and Refugee Board of Canada, Performance Report for the Period Ending March 31, 1996 (Ottawa: Minister of Public Works and Government Services, 1996) at $9,10$.
} 
This interval would also be fair to claimants, as it is generally recognized as enough time to allow for the collection of relevant evidence and for the claimant to prepare to testify. ${ }^{184}$ Although they appear efficient and economical, compressed timelines are actually neither: they are likely to engender multiple requests for extensions of time and result in incomplete evidentiary records and ensuing appeals and reviews. ${ }^{185}$ Compressed timelines are also not responsive to the realities of refugee status determination - to the plight of a trauma victim from a different country required to produce a narrative that is understandable in a different cultural and discursive context. Reasonable timelines, in contrast, meet concerns around accuracy and judicial sensitivity to context. There will be enough time to ensure that all information is gathered and to allow for the effects of culture shock, trauma and displacement to soften, but not so much time that memory will be distorted and the asylum seeker will suffer the ill-effects of a seemingly endless wait. Furthermore, the cost efficiencies around holding hearings promptly are obvious: there will be less money that will need to be expended on social benefits for those asylum seekers who are unable to work.

Circling back to the question of whether the Federal Court of Appeal could actually adhere to a maximum processing time (counted from the filing of the originating appeal document) and based on our earlier analysis, it does not seem entirely out of the question that error correction could be done within 6-9 months. The Federal Court is currently subject to legislated scheduling times for judicial review hearings on the merits (60 days), with which it has complied without obvious difficulty. ${ }^{186}$ Whatever timelines are ultimately selected, and before whatever forum (initial determination or appeal), it would seem critically important that these timelines be enshrined in legislation in order to provide an

\footnotetext{
${ }^{184}$ Showler supports this time frame for refugee determinations. Showler, Fair Fast and Final, supra, note 71, at 20.

${ }^{185}$ The Protecting Canada's Immigration System Act (Bill C-31),supra, note 1, the Canadian government's asylum latest reform initiative, envisions a total processing time of 216 days - with initial hearings taking place within 60 days and internal appeals completed within 105 days. Citizenship and Immigration Canada, "Backgrounder-Summary of Changes to Canada's Refugee System, supra, note 1.

${ }^{186}$ Immigration and Refugee Protection Act, supra, note 47, section 74(b).
} 
incentive for the government to keep both initial determination and appellate bodies properly staffed and accountable for their performance.

\subsubsection{Conclusion on structural reform}

These, then, are new structures that could form the backbone of a reformed refugee status determination system: a new initial determination body (either wholly judicial or para-judicial/interdisciplinary); a simplified all-in-one protection determination based on consolidated grounds that eliminates the need for separate subsidiary protection applications and the consequent review and stay applications; a new error correction mechanism that would see a written appeal on all protection grounds to the Federal Court of Appeal as of right; and legislated maximum processing times of 6 to 9 months each for initial determination and appeal. Structures, however, are only part of a refugee status determination system: the other aspect that needs to be explored is the question of how refugee claims are actually decided in practice and how this could be improved.

\subsubsection{Ideological reform: new approaches to refugee status determination in Canada}

\subsubsection{Overview}

Beyond new refugee status determination structures, what would happen if we had a new ideological approach to asylum? As with our suggestions for new structures, a new approach must advance the interests of stakeholders by promoting accuracy, efficiency and contextuality in the determination of claims.

We postulated that this could be achieved through an approach that is crisp, intelligent and informed, that breaks down communicative barriers and which allows the refugee's authentic voice to emerge. Specifically, and in response to previously identified areas of dysfunction, we propose exploring the establishment of 1)an improved profile for asylum decision makers that emphasizes expertise and professionalism; 2) a new hearing room dynamic that would privilege dialogue, inclusiveness and unfettered refugee speech; and 3) a 
new approach to credibility assessment that is tailored to the characteristics of refugees. In this section we will explain each new approach, assess their potential for enhancing accuracy, efficiency and contextuality in the system, and discuss possible methods of implementation.

\subsubsection{New decision-maker profile}

The first new approach that we will be discussing relates to improving the profile of asylum decision makers in Canada. There is a consensus in the academic literature around the characteristics of the ideal decision maker in the asylum context. He or she needs to be independent, informed, intellectually competent, self-aware, empathetic, possessed of an open mind and comfortable with uncertainty in order to deal with the most challenging aspects of refugee status determination - the assessment of credibility, fact finding and assessment of future risk. ${ }^{187}$ Empirical studies have revealed that the qualities which asylum seekers themselves value in decision makers are: intelligence, neutrality, compassion, attentiveness, patience and respectfulness. ${ }^{188}$

Some of these attributes are inborn and some are cultivated. Some are character traits and some are skills. Beginning with the latter, Rousseau et al suggest three competencies necessary for optimal performance in the refugee status determination milieu: legal, psychological and cultural. Legal competency includes the possession of legal knowledge and legal acumen. Psychological competency includes an ability to feel the suffering of others, experience dealing

\footnotetext{
${ }^{187}$ Barsky, Constructing a Productive Other, supra, note 20 at.187; Hardy, supra, note 32 at 482 483; Rosemary Byrne, "Assessing Testimonial Evidence in Asylum Proceedings: Guiding Standards from the International Criminal Tribunals" (2007) 19:4 Int'l J Refugee L 609, at 628; Jenni Millbank, “"The Ring of Truth': A Case Study of Credibility Assessment in Particular Social Group Refugee Determinations"; Crépeau \& Nakache, "Critical Spaces", supra note 57 at 64, 81; Rousseau, Crépeau, Foxen \& Houle, "The Complexity of Determining Refugeehood", supra, note 11 at 66; Kirmayer, supra, note 11 at 176; Rousseau \& Foxen: "The Myth of the Lying Refugee", supra, note 11 at 87 .

${ }^{188}$ Canadian Council for Refugees, "The Experience of Refugee Claimants", supra, note 70 at 2; Rousseau \& Foxen, "Look Me in the Eye", supra, note 11 at 82-87; Erin Rider, Negotiating Uncertainty in the Right to Asylee Status: Re-conceptualizing Agency from a Space of Liminality, PHD Dissertation, Texas Woman's University, 2010 [unpublished], at 148-149.
} 
with trauma victims and exiles, and an ability to understand and withstand vicarious traumatization. Cultural competency includes experience with other cultural milieus, through field work, for example. ${ }^{189}$ For Rousseau and her colleagues, these three competencies reflect the complexity of refugee status determination; and, as alluded to earlier, this interdisciplinary vision of refugee status determination suggests that lawyers, psychologists and culturally competent persons (country of origin natives or even anthropologists) could be well-placed as decision makers-preferably sitting in tandem. What is more, such expertise may tend to foster professionalism, which in turn would help to ensure independence. Speaking of the current IRB, a study by Crépeau and Nakache found that "since many Board members were not experts they did not perceive themselves as such, and did not act as such. It seems no common institutional culture has been created that would instil a feeling of being strong enough to resist external influence." 190

A vision of expert decision makers is certainly theoretically feasible - in either a wholly judicial or para-judicial model for refugee status determination. The vision would be similar to what the TAQ attempts to achieve by requiring panel composition that reflects an array of appropriate expertise. Developing legal, psychological and cultural competencies in asylum decision makers might be achieved through dissemination and reception of strategic informationinformation about refugee law, information about country conditions and cultural norms, information about the psychology of exile, information about the limits of memory, information about cross-cultural communication, information about narrative, information about stereotypes and negative discourse, information about lie detection and interviewing techniques - even information about the asylum decision making process itself. As Herlihy and Turner have pointed out:

\footnotetext{
${ }^{189}$ Rousseau, Crépeau, Foxen \& Houle, “The Complexity of Determining Refugeehood”, supra, note 11, at 66. Some have even suggested the use of a "cultural interpreter". See Robert Barsky, "The Interpreter as Intercultural Agent in Convention Refugee Hearings" (1996) 2:1 The Translator 45, at 50. See also on the issue of cultural competency: Satwinder Juss, "Towards a Morally Legitimate Reform of Refugee Law: The Uses of Cultural Jurisprudence" (1998) 11 Harv Hum Rts J 312.

${ }^{190}$ Rousseau, Crépeau, Foxen \& Houle, “The Complexity of Determining Refugeehood”, supra, note 11 , at 117 .
} 
The processes at work in the minds of claimants, interviewers and decision makers need to be carefully and systematically identified and understood in this setting. Collaboration across disciplines could ensure that this work is comprehensive and cohesive so that we can be more confident that the best knowledge - empirical, clinical, and judicial — is brought into play in what may be life or death decisions. ${ }^{191}$

Brian Gorlick has even suggested that an "international training college for refugee law judges" should be established where they could study not only law, but "psychology, anthropology, human geography and the use and limits of forensic evidence." 192

Aside from skills and expertise, how would we develop the character traits identified as crucial to asylum decision making, namely, open-mindedness, empathy, self-awareness and comfort with uncertainty? Open-mindedness, for instance, tends not to be an acquired trait, except that higher education and exposure to other ways of being and thinking could enhance it. Whether we could test potential asylum decision-makers for mental attributes (perhaps through psycho-metrics) is something that is a bit Orwellian, but still worth exploring. Discourse theorist Cynthia Hardy expresses the hope that achieving the proper mindset could be simply a matter of training. She believes that officials should be

trained to tolerate ambiguity in information rather than seek convergence. In this way they are more likely to understand the socially constructed nature of truth and the constructive effects of using particular knowledge and, in so doing, have a more finely grained appreciation of their work". ${ }^{193}$

In point of fact, Foxen and Rousseau's study of former IRB members confirms that a significant number of them already seem to have been able to achieve a decisional mindset whereby they were able to

cast doubt on the possibility of objectively determining what is true and what is false and attempt, beyond or rather via the twists and turns of the refugee's story and strategic 'lies', to apprehend partially what the refugee has lived through and to translate it in terms of a legal decision". ${ }^{194}$

\footnotetext{
${ }^{191}$ Herlihy and Turner, supra, note 11, at 192.

192 Brian Gorlick," UNHCR Working Paper No. 119: Improving decision-making in asylum determination" UNHCR, August 2005. Jenni Millbank has identified decision maker training as key as well, particularly in relation to credibility assessment, supra, note 187 at 6 .

${ }^{193}$ Hardy, supra, note 32, at 482-83.

${ }^{194}$ Rousseau \& Foxen: "The Myth of the Lying Refugee”, supra, note 11, at 88.
} 
Foxen and Rousseau also found indications that there is a "moment in which the traumatic experience of suffering related to the refugee's losses, insecurity or fear can suddenly intrude into the Board member's realm of experience..." causing the members develop an "innermost conviction" that asylum should or should not be granted. ${ }^{195}$ These moments, in essence, are moments of human to human contact between asylum seeker and decision maker-moments where the refugee is seen, not as "other", but as fellow human being. However, decision makers would need be open to these moments - and want to search for them. They would need to be possessed of an open and empathic mindset that allows for the ability not only to negotiate uncertainty, but also to establish an insightful and revealing connection with individual claimants.

How would the new decision-maker profile discussed above enhance accuracy, efficiency and juridical sensitivity to context in decision making? It seems axiomatic that having a wide range of knowledge (legal and otherwise) at one's fingertips can not only aid in correctly identifying refugees, but serve to enhance one's knowledge of the context of forced exile as well. Furthermore, expert decision makers are also efficient decision makers in the sense that they are making economical use of resources already expended around the study of asylum. Most of the useful information on asylum decision-making emanates from academics who have already benefited, either directly or indirectly, from public funding - and an argument can be made that it ought to be put to good use. As well, expert decision makers are likely to be able to do their jobs more rapidly, since they can home in on the essential questions and grasp the issues at play in a refugee case more quickly than lay persons. In this way, expertise finds its relation to simplicity, economy and timeliness - the components of efficiency.

Which brings us to the practical question of how best to change the asylum decision maker profile from lay to expert, from indifferent to empathic, and from closed to open-minded. It is possible that the requisite expertise could be achieved both through enhanced selection procedures and enhanced training. Selection criteria could be established and, ideally, legislated so that there can be

${ }^{195}$ Ibid. 
no derogation therefrom. The criteria could be tailored to increasing accuracy, efficiency and contextual sensitivity in conformity with the challenges inherent in refugee status determination. In a wholly judicial model, the qualities already demanded of the Canadian judiciary should suffice, ${ }^{196}$ and to those could be added a specialized background (like the Tax Court judges have) as well as the specialized training discussed above. ${ }^{197}$ In a para-judicial/interdisciplinary model, expertise might be ensured by requiring an undergraduate or graduate degree and a minimum of 5 years practice in selected areas (law, psychology, anthropology, sociology, etc.), ideally in combination with cross-cultural experiences. Additional necessary information could then be imparted by way of specialized on-going professional development programs. But as for the necessary open and empathetic mindset, short of the psycho-metric testing alluded to earlier, there is no sure-fire method of achieving this, apart from requiring personal interviews and references, as well as knowing which characteristics to look for.

\subsubsection{New hearing room dynamic}

We now turn to a discussion of the second area of ideological reform: the question of a new hearing room dynamic - one that could enhance the accuracy, efficiency and contextual sensitivity of the asylum process by facilitating free and undistorted communication and experiential exchange between claimant and decision maker. We will explore two new interrelated and complementary hearing

\footnotetext{
196 In Canada, the merit based criteria for federal judges include "general proficiency in the law, intellectual ability, analytical skills, ability to listen, ability to maintain an open mind, ability to make decisions, capacity to exercise sound judgment, .....awareness of racial and gender issues, bilingual ability and such personal characteristics as sense of ethics, patience, courtesy, honesty, common sense, tact, integrity, humility, fairness, reliability, tolerance, sense of responsibility and consideration for others". See Commissioner of Federal Judicial Affairs, Assessment Criteria, Candidates for Federal Judicial Appointment, online: http://www.fja-cmf.gc.ca/appointmentsnominations/assessment-evaluation-eng.html.

${ }^{197}$ Hathaway described such training in the following terms in Rebuilding Trust, supra, note 49, at $25:$

Nongovernmental, advocacy, and academic resources should be drawn upon in structuring and conducting these training programs, both to generate an atmosphere of openness and full confidence among all relevant constituencies, and to ensure that all matters of real concern to stakeholders are in fact addressed in a comprehensive and meaningful way.
} 
room dynamic models: the dialogic model and life story model, both of which are implicitly proposed as possible alternative models in the academic literature.

\subsection{Dialogic Model}

Robert Barsky applies the thought of Michael Bahktin (on discourse theory and dialogism) and C. Bourdieu (on interaction theory) to refugee status determination and comes up with a vision of a "dialogic" dynamic between claimant and decision-maker:

Bourdieu's analysis, if applied to the hearing, suggests that an open-ended form of interrogation might work to the advantage of both decision-makers (by lending itself more readily to the discovery of unexpected facts) and the refugee (who will have the opportunity to connect apparently disparate experiences that are related to the claim). ${ }^{198}$

For Barsky, "the utopic form of such exchanges as oral hearings" are those "where the parties to the hearing have relative freedom and where there is a measure of equality between the interrogator and the interrogated." 199 Barsky notes that this truly dialogic dynamic of mutual communication is not present in Canada's current refugee status determination model:

The practical bureaucratic aspect of refugee hearings, the fact that the first priority is to process and adjudicate rather than to 'understand' the discourse and profit from the presence of a foreigner, serves as a barrier to Bakhtin's vision of a world that 'becomes polyglot once and for all and irreversibly'...

Bakhtin's work suggests the need for a method of accounting for intonation and non-verbal discourse, a carefully, screened interpreter, a loosely-structured hearing, well-informed counsels and officials, and flexible strategies for assessing contradictory or impertinent testimony. The adoption of this methodology, along with other tools of discourse analysis previously discussed, would help unearth, rather than bury, the dialogism of the Convention Refugee Claimant. ${ }^{200}$

In other words, the dialogic model is one which privileges open-ended speech, equality between claimant and decision maker, mutual understanding and a cosmopolitan ideal. ${ }^{201}$ The hearing room dynamic would ideally be interactive,

\footnotetext{
${ }^{198}$ Barsky, Constructing a Productive Other, supra, note 20, at 89.

199 Ibid,at.90.

${ }^{200}$ Ibid at 187, 201. Barsky cites Bahktin's Dialogic 12.

${ }^{201}$ See Lydia Morris, Asylum, Welfare and the Cosmopolitan Ideal: A Sociology of Rights (New York: Routledge, 2010).
} 
but with little curtailing or redirection of the refugee's speech. Asylum seekers would be allowed to simply tell their stories in whatever way they see fit at the moment of the hearing in the presence of an attentive, patient, and supportive decision maker. ${ }^{202}$ In fact, this is what refugees consistently say that they want from their hearings. ${ }^{203}$ Thus, the term "dialogic" implies not only ordinary dialogue, but also the recognition and acceptance of discursive and ontological multiplicity.

Academic research on intercultural communication strategies also sheds light on how and why a dialogic model of interrogation might be more appropriate for refugee status determination than the current approach. David Shea disputes the notion that discursive "mismatch" is what causes insurmountable difficulties in cross-cultural communication. He states:

In place of the mismatch approach, I have presented an analysis of the varying quality of the interlocutor response. I contend that the responsive character of speaker engagement serves to structure the discursive position of the NNS [nonnative speaker]. Recognizing the fundamental importance of reciprocity in conversation entails that communication between NSs [native speakers] and NNSs be democratically enacted where interactants dialogically "share" in the formulation of the conditions of knowledge and futurity. ${ }^{204}$

In studying examples of intercultural conversations, Shea concludes that nonnative speakers express themselves best when their speech is met with a "supportive amplifying response." 205 That is, the native speaker "not only takes what (the non-native speaker) says and incorporates it into her own talk, she also grants (the non-native speaker) interactional authority to shape the direction and character of the conversation", 206

Although Shea was studying persons who were expressing themselves directly in a foreign language (rather than through an interpreter), his observations gel nicely with Barsky's attempt to use discourse analysis to improve the refugee

202 "Letting the refugee speak" is a key part of other reform proposals. See Showler, Fair, Fast, Final, supra, note 71 at 12 and Martin, supra, note 130 at 1350-1351.

${ }^{203}$ Canadian Council for Refugees, The Experience of Refugee Claimants supra, note 70, at 38-42; Rousseau \& Foxen, "Look Me in the Eye", supra, note 11 at 82-87; Rider, supra, note 185 at 148149 .

${ }^{204}$ David P Shea, "Perspective and Production: Structuring Conversational Participation across Cultural Borders" (1994) 4:3 Pragmatics 357 at 383.

205 Ibid at 378 .

206 Ibid at 374. 
hearing. Both advocate for a non-hierarchical, interactive setting for crosscultural communication. According to Shea's ideas, Kalin's "troubled communication" can be overcome by decision makers who listen to, adopt and go with the flow of the speech of the refugee claimants appearing before them. This approach is supported by the work of Jane Herlihy and Stuart Turner who note that that the attitude of the listener is crucial in asylum cases. ${ }^{207}$ Turner in particular is a firm believer in the benefits of dialogue. ${ }^{208}$ As well, one refugee claimant studied by Rousseau and Foxen seemed genuinely grateful when a Board member finished her sentences for her-an instance of non-native-speaker speech adoption by the listener. ${ }^{209}$

There is also a train of thought that suggests that adherence to dialogism in the asylum process is appropriate because the exile experience is itself dialogic: the refugee's perception of self is continually shifting. According to Alan Desantis, this dialogism is reflected in refugee narrative and the latter cannot be properly interpreted without acknowledging this fact. ${ }^{210}$ A dialogic model contrasts sharply with the current monologic one where, as Barsky observes, the refugee claimant is asked to provide one detailed written narrative shortly after arrival and is (effectively) not allowed to depart from that narrative. What academic thought shows is that this is often not possible for genuine refugees given the liminality they experience. Thus, it would be seem beneficial if the hearing were not primarily a presentation (monologue), but more of a give-andtake (dialogue) that allows for different ways of being and knowing and attempts to negotiate them-both as between refugee and listener and as between the refugee's competing internal selves. This negotiation process could allow for mutual understanding, self-understanding and, ultimately, a more complete picture of the refugee's case. ${ }^{211}$

Dialogue in its ordinary sense also seems more likely to elicit empathy than presentation and monologue, which tend to promote detachment. (Compare

\footnotetext{
${ }^{207}$ Herlihy \& Turner, supra, note 11 at 185 .

${ }^{208}$ Turner ,supra, note 12 at 67.

${ }^{209}$ Rousseau and Foxen, "Look me in the Eye" supra, note 11 at at 85 .

${ }^{210}$ De Santis, supra, note 11, at 6. See also Shuman and 1 Bohmer, supra, note 11 at 410 .

${ }^{211}$ See De Santis, supra, note 11at 15-16.
} 
the experience of being able to converse with someone about his or her traumatic experiences with having to watch him or her describe it on television). Psychologists believe that, once elicited, empathy allows the decision maker to see and feel the claimant's need for protection and take morally correct action in the form of granting asylum. ${ }^{212}$ Empathy seems to be what bridges the cultural gap between asylum seeker and host community and promotes acceptance. Dialogue also validates both speech and speaker in a way not possible with monologue. One refugee studied by the CCR desperately wanted to dialogue with the Board member hearing her case:

"She didn't give me any clue. I just answered and she asked the next question, just like that. 'Did I say the right thing? Did I miss something? Did I explain myself well enough? Did she believe me?' I had that all the time. That nervousness, that stress was in me throughout the question period. When I'm talking with [my lawyer]...I get a reaction. ${ }^{213}$

De Santis' plea for the triumph of dialogue over monologue in the asylum context is compelling and bears repeating by way of conclusion:

Traditional monological analysis forces a simplistic template that creates 'false unities' on all that it surveys. Locked in a Classical paradigm, monological thinking denies the possibility of contradicting ideas existing simultaneously. Bakhtin's dialogical ontology, however, supplies researchers a new polylogical perspective with which to view language....

When Bakhtin's dialogism is used to revisit the discourse of exiles, a more complex and sophisticated understanding of their lives and experiences emerges. Their contradictions, simultaneities and conflicts are recognized, not as psychological flaws or illogical thinking, but as manifestations of the centripetal/centrifugal forces at work in their lives...

It is suggested, therefore, that we begin to listen to exiles' stories through a new theoretical frame that allows them to be heard and understood in their own terms. ${ }^{214}$

\subsection{Life Story Model}

Distinct from, but complementary to, the dialogic model for hearing asylum claims is the "life story" model. Several discourse theorists and psychologists favour a holistic approach to interrogation of asylum seekers that

\footnotetext{
${ }^{212}$ Rousseau and Foxen, "Look me in the Eye", supra, note 11 at 72.

213 Canadian Council for Refugees, The Experience of Refugee Claimants, supra, note 70 at 45.

${ }^{214}$ De Santis, supra, note 11, at 15-16.
} 
seeks to elicit, not simply their experiences of persecution, but their entire life story, of which the persecution might be one (and not even the final) chapter. Not only is life-storytelling therapeutic for refugee claimants as they try to come to terms with past, present and future versions of themselves, ${ }^{215}$ it can also be illuminating for decision makers. As former refugee, Halleh Gorashi, discovered when interviewing Iranian women in the Netherlands and the United States,

The life story as method....offers space for the unsaid, the indescribable and the incomprehensible. The opportunity to have a lengthy conversation about life in chronological order creates a space in which moments of silence and the expressions of emotions become visible. ${ }^{216}$

Moreover, the glimpse of emotion in a claimant's testimony can be a lifeline to a decision maker struggling with questions of truth or falsehood. Thus, taking a holistic approach to the refugee's story-hearing about his or her background, family, village, occupation, social position, the onset of trouble, flight and his or her life in the host country - has the potential to create a clearer picture of the claim and possibly a better context in which to assess its genuineness. Robert Barsky even suggests that a knowledge of narratology might be helpful to decision makers in the refugee context by allowing them to isolate "the many voices that speak through a single narration" in the hope that a single authentic voice may emerge. ${ }^{217}$ Furthermore, there is a theory that, at a deeper sociological level, storytelling fosters connections between in-groups and out-groupsbetween host community and asylum seeker. In promoting the usefulness of storytelling in a legal context, Richard Delgado notes:

\footnotetext{
${ }^{215}$ Turner, supra, note 11 at 67-68 ("Producing a testimony not only helps to relieve symptoms; it also helps survivors to integrate the trauma story into their personal histories by allowing them to understand its significance in the context of political and social events"); Turner even suggests that we need new asylum systems "designed to facilitate recovery" by displaying refugees' need to rebuild trust relationships (at 63). See also Arthur Saniotis, "Polemics of Healing: Storytelling, Refugees and Futures" (2008) 12:4 J of Futures Studies 1.

${ }^{216}$ Halleh Ghorashi, "Giving Silence a Chance: The Importance of Life Stories for Research on Refugees" (2007) 21:1 J of Refugee Studies 117 at 127.

${ }^{217}$ Barsky, "Narratology", supra, note 26 at 288.
} 
Stories are the oldest, most primordial meeting ground in human experience. Their allure will often provide the most effective means of overcoming otherness, of forming a new collectivity based on the shared story...

Deliberately exposing oneself to counter stories... can enable the listener and the teller to build a world richer than either could make alone. On another occasion, the listener will be the teller, sharing a secret, a piece of information, or an angle of vision that will enrich the former teller; and so on dialectically, in a rich tapestry of conversation, of stories. It is through this process that we can overcome ethnocentrism and the unthinking conviction that our way of seeing the world is the only one - that the way things are is inevitable, natural, just and best-when it is for some, full of pain, exclusion and both petty and major tyranny. ${ }^{218}$

Using life-storytelling as the adjudicative framework for the granting of asylumeven in a loose sense-fits in well with both the dialogic ideal and the expressed desires of refugees themselves. Not only would refugees fulfill their deep-seated "need to be seen and heard", 219 decision makers would also, as Delgado suggests, be free to interject their own stories - stories of difficulty understanding or believing or functioning in the realm of refugee status determination. Once refugee and decision maker fully address each other's stories, melding of their disparate worlds becomes theoretically possible. Furthermore, if refugees present their claims as life stories, it may become easier to see embellishment, metaphor and poetic license in the narrated tale not as lying, but as normal in the narrative context, and as simply a way of conveying their own experience across the cultural divide. On the flip side, as alluded to earlier, the manner in which the claimant situates the persecution within his or her life story might also aid in indentifying fabrication. For instance, does the claimant seem to have internalized his or her persecutory experiences or is there a suspicious sense of detachment? Does the persecution play a defining or peripheral role in the life story? While this type of assessment cannot necessarily serve to prove or disprove the genuineness of the claim, it would seem at least to have the potential to provide the decision maker with some important clues.

\footnotetext{
${ }^{218}$ Richard Delgado, "Storytelling for Oppositionists and Others: A Plea for Narrative" (1989) 87 Mich Law Review 2411 at 2438, 2439.

${ }^{219}$ Rousseau \& Foxen; "Look me in the Eye", supra, note 11, at 82.
} 
Both the dialogic model and a life story model for refugee hearings have the potential to enhance understanding and therefore improve communication and reception of information, which in turn may well increase the likelihood of a correct decision on asylum. Juridical sensitivity to context would likely flow from this new hearing room dynamic as well, in as much as dialogue and storytelling function as learning experiences for the decision maker. These models may also be more efficient approaches in that they privilege a direct connection between claimant and decision maker. Under the current system (and most adjudicative structures) the decision maker is passive, rather than engaged. Although this passive approach traditionally has been seen as a way to preserve judicial neutrality, it is not particularly efficient. Counsel or claimant can only guess what information is most important to a decision maker in any given case. If reducing distortion and mediation are ideals, direct contact between decision maker and claimant should be encouraged to the greatest extent possible and appropriate. ${ }^{220}$

Nonetheless, in terms of efficiency, open-ended questions and life story recitations do raise valid concerns about an increase in the length of hearings. For instance, Barksy (as per interaction theory) envisages the dialogic hearing room scenario as one in which "speakers are free to roam from subject to subject, theme to theme, while the interviewer awaits the right moment for further questioning...." ${ }^{221}$ Care must be therefore taken to ensure that using one or both of these new models would not be counterproductive. The dialogic and life story models should only be strictly adhered to to the extent that the hearing can be concluded within the usual three-hour time frame. If not, a more focused approach will have to do. In any event, it may well be that the time taken up by longer claimant statements will be offset by time saved through eliminating pointless questioning by non-decision making participants in the hearing and the frequent interruptions, backtracking and confusion that the current model often entails.

\footnotetext{
${ }^{220}$ Hathaway, "Rebuilding Trust", supra, note 49, Recommendation 11, at 79.

${ }^{221}$ Barsky, Constructing a Productive Other, supra, note 20 at 96.
} 
How would the foregoing suggestions from the academic literature be implemented in practice? It is important to remember that the dialogic model and the life story approach are simply interrogation techniques. There should theoretically be no insurmountable difficulty in incorporating them into a nonadversarial hearing structure, and some existing decision makers may unconsciously be employing elements of these techniques already. As noted earlier, these techniques may not be appropriate for every case. Nonetheless, if a wholly-judicial model for refugee status determination would be adopted, there could be a legitimate concern over, whether judges would be able to engage with claimants effectively in the manner required by the dialogic and life story approaches. ${ }^{222}$ In response, one might say that, while in many ways the hearing dynamic proposed is antithetical to that which exists in a traditional courtroom, the dynamic is nonetheless generally consistent with an inquisitorial model-and therefore something with which judges should be reasonably familiar and able to negotiate while still fulfilling their obligations as jurists to apply and respect the rule of law. A fitting example in this context, as pointed out by Rosemary Byrne, is the case of the International Criminal Tribunals for Rwanda and the Former Yugoslavia (ICTR and ICTY):

Within Trial Chamber I of the ICTR, where the most developed set of evidentiary principles for the oral testimony of witnesses and victims has emerged, there has been a concurrent evolution in the role of the bench. The presiding judge actively exercises his or her discretion to redress the potential distortions that arise from cultural, psychological, educational and distance barriers over time. Where testimony is not narrated in a manner appropriate for the judicial context, the responsibility is taken by the bench to reframe questions and adopt alternative mechanisms for extracting the required information. The proactive role of the judge serves as a corrective mechanism for the modes and methods of communication that characterize human rights testimony. ${ }^{223}$

Thus, even in the highly formal and adversarial context of the ICT, judges have been able to adopt a more engaged role in the better pursuit of justice for victims of human rights abuses. Asylum Court judges could presumably do this as well, if called upon to do so.

\footnotetext{
${ }^{222}$ This is unlikely to be a problem if a para-judicial Board model for refugee status determination were adopted.

${ }^{223}$ Byrne, supra, note 187 at 637.
} 


\subsubsection{New approaches to credibility assessment}

The new approaches to refugee status determination we have discussed thus far are: 1) a new profile for decision makers and 2) a new hearing room dynamic. The final issue that must be addressed in this regard relates to approaches that will facilitate credibility assessment. It would be interesting to try to develop an approach that would allow us to more reliably distinguish genuine refugees from fortune seekers and which would proactively discourage lying, substitution and borrowing. Academic thought and empirical evidence suggest that, in order to achieve these goals, we should privilege an approach which is able to cope with uncertainty and avoid seeing "truth" in the asylum context as fixed and unitary. It should be an overall more informed approach and one that is able to adjust for the limits of human memory, cultural difference and the effects of trauma. Most of all, it should ideally be an approach which encourages and allows refugees to tell their own story - and not the story of another or the story we expect them to tell - and to tell it only once, thereby helping to avoid the narrative overkill that plagues the current system. We will explain the various elements of this approach in detail as follows.

\subsection{Coping with uncertainty}

The grant of asylum is based on findings of fact-facts about the claimant's motivations and facts about the likelihood of harm. The problem is that we can never know for certain how things actually happen in far-away physical and psychological places; we can only see through a glass darkly. For decision makers, this fact can be very difficult to cope with. ${ }^{224}$ For many of them, as long as the refugee claimant remains a cipher, the outcome of the claim must be negative. As Jenni Millbank points out:

\footnotetext{
${ }^{224}$ For an illustration, see Peter Showler, Refugee Sandwich (Montreal \& Kingston: McGillQueen's University Press 2006) at 182-209.
} 
This notion of truth as objective and discoverable by a decision-maker who is a fact "finder" - rather than, say, a probability estimator, one who knows that their state of knowledge can only ever be imperfect and who weighs various possibilities and decides to give or withhold the benefit of the doubt-is surprisingly prevalent given the well-known vicissitudes of proof in the refugee context. $^{225}$

Some authors have suggested that the best way to cope with this uncertainty is to have a legislated benefit-of-the-doubt rule requiring decision makers to accept the refugee's account as accurate unless there is evidence to the contrary. $^{226}$ While this notion is in keeping with pre-existing common law rules in any event, ${ }^{227}$ it might nonetheless be problematic_particularly when viewed from the perspective of the host community's legitimate interest in accepting only those genuinely in need of asylum into the fold. The problem with the benefit of the doubt rule in the asylum context is that there is rarely "evidence to the contrary". In most cases, the only evidence of anything is the refugee's narrative - and it can neither be proven nor disproven due to the temporal, spatial and cultural divide. Thus, to grant asylum just because there is doubt might go too far in the direction of giving fortune-seekers a free pass. ${ }^{228}$

In our view, it might be better to draw on Marita Eastmond's observations on the nature of refugee discourse, ${ }^{229}$ and ask a different question-namely, not whether the claimant's testimony is true or false, but to what extent "life as lived" is reflected by "life as told" or "life as text". It might be better to summon all our knowledge about the peculiar nature of refugee status determination, and assess the refugee's statements in the light of that knowledge. Some statements might be entirely accurate portrayals of reality, some may be embellishments, some metaphor, some borrowings. The key would be to find a core set of facts (or even

\footnotetext{
${ }^{225}$ Millbank, supra, note 187 at 5 .

${ }^{226}$ Durst, supra, note 11 at 174; Michael Kagan "Is Truth in the Eye of the Beholder? Objective Credibility Assessment in Refugee Status Determination”, 2002-2003 17 Geo Imm L J 367, at 414-415.

${ }^{227}$ The Federal Court has ruled that the sworn testimony of refugee is to be presumed true. See Maldonado v MEI [1980] 31 NR 34 (FCA).

${ }^{228}$ Durst, supra, note 11, argues that a cost-benefit analysis favours a benefit-of-the-doubt rule on the premise that the number of outright false claims (fortune seekers) is very low. Unfortunately, this premise cannot be proven true or false.

${ }^{229}$ Eastmond, supra, note 11 at 249-250.
} 
emotions) that can be believed and to see if these would constitute grounds for asylum. Such an approach would be to negotiate uncertainty-not give in to it.

Nonetheless, there will be likely times when, even after using our best efforts to assess the credibility of a claimant, there will still be uncertainty. At that point there is a policy choice to be made about whether it is preferable to grant refugee status in the face of uncertainty (and thereby potentially allowing a fabricator into Canada) or to deny it (and thereby potentially sending a genuine refugee back to persecution). Canada's humanitarian tradition would theoretically dictate that asylum decision makers make it their mantra to err in favour of the genuine refugee in these circumstances. However, it seems that Canadian society is not entirely comfortable with this policy, nor can it even embrace or accept its discomfort. There may a need for more forthright discussion around this point.

\subsection{Assessing refugee testimony}

Given the fact of uncertainty, decision makers should have the best possible tools for distinguishing between fortune seekers and genuine refugees, so that they (and the Canadian public) can feel more confident in their decisions to grant or deny asylum. Arguably, fortune seekers who fabricate a story out of thin air are the only types of claimants who deserve to be labelled as "not credible" (although neither should they be demonized). But, in order to avoid injustice, it is crucial to distinguish these fortune seekers from those claimants who are merely human-prone to faulty memory, the after-effects of trauma or strategic selfpresentation as an attempt to come to terms with self-exile or simply "borrowers" like Caroline from Chapter 1. Decision makers should ideally be alive to the psychological, medical, cultural and institutional factors that could adversely affect a refugee claimant's testimony. For instance, decision makers may benefit from being continually reminded of the literature on the fallibility of human memory-Hilary Cameron's $\operatorname{article}^{230}$ usefully summarizes it-as well as conventional wisdom on the effects of trauma and the psychology of exile. Not

\footnotetext{
${ }^{230}$ Cameron, supra, note 34.
} 
only is there a wealth of written materials on this subject, there are professionals in the field of psychology devoted to assisting asylum decision makers. ${ }^{231}$ Access to this knowledge could be imparted to decision makers - be they wholly judicial or para-judicial-through on-going training programs. Furthermore, decision makers should be aware of the shortcomings of the science of lie detection-particularly in the cross-cultural context. At least, as Hilary Cameron and A. Vrij point out, decision makers could be trained to "avoid paying attention to non-diagnostic cues" ${ }^{232}$ - such as gaze aversion and fidgeting. ${ }^{233}$

The issue of prior statements also deserves attention here. Decision makers may wish to avoid demanding perfect correspondence between claimants' testimony at the asylum hearing and prior statements given in different contexts, for it is well known that a person will recount the same experience in a different way depending on the audience and purpose of speaking. ${ }^{234}$ Since such perfect correspondence is frequently impossible in the asylum context, prior statements and restatements of the claimant's story tend to become fodder for adverse credibility determinations based on "contradiction" and "inconsistency".

In fact, it would be beneficial to look at an overall reduction in the amount of narrative required of refugee claimants. There is considerable support in the academic literature for the proposition that claimants should be required to tell their story at their hearing and in no other prior context. For instance, Juliet Cohen argues forcefully against reproducibility of narrative as a measure of credibility in the asylum context on account of, not just the vagaries of normal

\footnotetext{
${ }^{231}$ The Centre for the Study of Emotion \& Law in the U.K. for instance (home to Jane Herlihy, supra, note 11) http://www.csel.org.uk/. See also McGill University, Faculty of Medicine, Department of Psychiatry, Division of Socially and Transcultural Psychiatry (home to Cecile Rousseau and Laurence Kirmayer, supra, note 11).

${ }^{232}$ Cameron, supra, note 34 at 510; A. Vrij, "Why professionals fail to catch liars and how they can improve" (2004) 9 Legal and Criminological Psychology 159 at 171.

${ }^{233}$ Vrij, ibid, at 164-165. Vrij argues that individuals can be trained to take individual and situational differences into account, focus on speech content, look for signs of cognitive load, look for comparable truths, try making the speaker nervous, ask for elaboration, or even use a computer program that keeps track of the number and quality of the words used by the speaker. Whether these strategies would be effective with regard to asylum hearing testimony is not known.

${ }^{234}$ Eastmond, supra, note 11 at 250, Herlihy \& Turner, supra, note 11, at 187; Herlihy, Scragg \& Turner, supra, note 79 , at 327 .
} 
memory, but the immediate, short and long-term effects of trauma as well. ${ }^{235}$ Jane Herlihy provides empirical data on this point. ${ }^{236}$ Barsky's discourse analysis portrays the taking of prior statements, not only as an opportunity to "trip up" the claimant, ${ }^{237}$ but also as fundamentally limiting:

The information asked is purely empirical, chronological and absolutely related to the initial statement....The process encourages, nay, demands, this kind of reduction and precision. There is no whole human being at the end of such a process; there is the Other as Convention refugee claimant, the Other as repetition and clarification of the original statement...

The refugee claim system whittles down the claimant as Other to a small series of contradictions which justify a negative decision. ${ }^{238}$

Multiple prior statements have the potential to sidetrack and distort the communicative process at the refugee hearing, impeding the chances of correct decisions. The existence of such statements also complicates the hearing process, with considerable amounts of time being spent on reconciling the claimant's previous iterations of his or her story. As explained earlier, prior statements are not necessarily reliable aids in uncovering "truth" in the asylum context.

One way to implement these ideas around reducing narrative is to dispense with the detailed written asylum application altogether. Kirmayer sees the provision of an initial statement as unreliable as a fact-finding tool, given that it "is written shortly after arrival during a time of anxiety and radical uncertainty, when the asylum seeker lacks a definite social status and familiar context with which to anchor and stabilize his self-understanding." 239 Instead, the claimant might simply be required to file a "Notice of Asylum Claim" with the first level decision maker (be it the Asylum Court or the Asylum Tribunal, as per our suggestion). This form could be a legal document, to be filled out by counsel. It could simply state basic information, such as country of origin, the category of relief relied on (refugee status, protected person status, humanitarian asylum) and the Convention ground relied on (race, religion, etc.) - in other words, just

\footnotetext{
235 Juliet Cohen, "Questions of Credibility: Omissions, Discrepancies and Errors of Recall in the Testimony of Asylum Seekers," 2001 13:3 Int J Ref L 293, at 308.

${ }^{236}$ Herlihy, Scragg and Turner, supra, note 79, at 327.

${ }^{237}$ Barsky, Constructing a Productive Other, supra, note 20, at 132.

${ }^{238} \mathrm{Ibid}$, at 218,231

${ }^{239}$ Kirmayer, supra , note 11 at 174.
} 
enough information to ensure the proper country condition and human rights information could be obtained for the hearing. We may also wish to think seriously about discontinuing the practice of having immigration officials conduct interviews with claimants at the port of entry about their experiences of persecution, as the notes of this interview (sometimes riddled with errors and misunderstandings) almost inevitably find their way into the file of the IRB member, and become fodder for adverse credibility determinations.

By curtailing these prior statement opportunities, the hearing itself would likely emerge as the central focus of the claim. The hearing would then become the place where the story is told officially for the first time, once and for all, ${ }^{240}$ thus virtually eliminating the chances of there being differing versions of events attributable to the limits of human memory, the effects of trauma or the vagaries of the narrative process. There is some real-world precedent for this hearingcentered approach. Returning again to the ICTs, Rosemary Byrne notes:

Trial Chambers take a restrained approach to attaching significant probative weight on inconsistencies from prior statements. The rationale for this is based on the same set of circumstances that affect asylum proceedings: lapses in time between earlier and later statements, the language barriers in interviews, absence of clarity regarding the original questions put to witnesses, risk of errors in interpretation and transcription, and the potential impact of trauma......The evidentiary consequence is that the Chamber considers the court room testimony as its point of departure. This allows for the development of narrative testimony independent of the confines of the content and scope of prior statements. ${ }^{241}$

Elimination of the central position of the Personal Information Form (or documents like it) at the hearing is a radical change, but one that could be in the best interests of claimants, since this type of document can be more of a hindrance than a help to effective communication and efficient hearings. On the other hand, placing the entire focus on the refugee's viva voce testimony might be seen as limiting, as there is essentially only one opportunity to communicate optimally. In any event, whether the advance written statement is eliminated or not, it would nonetheless be worthwhile to make a concerted effort to have decision-makers

\footnotetext{
${ }^{240}$ Counsel will, of course, have prepared the claimant to testify by drawing out his or her story.

${ }^{241}$ Byrne, supra, note 187 , at 633 .
} 
view any prior statements that have been made in the same comprehending manner as the judges of the ICTs.

Decision makers would also do well to make use of cultural information when assessing credibility. Some authors have suggested using incorporating "cultural interpreters" as well as linguistic ones into the refugee process. ${ }^{242}$ At minimum, anthropological information should be made available so that decisionmakers are aware of social and cultural conventions (such as avoiding eye contact, or speaking indirectly) that may be mistaken for duplicity. ${ }^{243}$

\subsection{Borrowing and substitution}

Finally, it may be worthwhile exploring creative ways of reversing the authenticity deficit that seems to inhere in the asylum process. In the case of fortune seekers who fabricate claims because they have no hope of immigrating, guest worker programs might theoretically divert these individuals from the refugee stream. ${ }^{244}$ For those claimants who have genuinely suffered, but who embellish, tell "protective" falsehoods or purchase ready-made stories, it would be prudent to reduce or eliminate the need for them to do so. As Barsky notes: "The refugee must be made to feel comfortable and confident with his or her own story so that he does not feel the need to rely upon erroneous advice". ${ }^{245}$ As discussed earlier, preventing borrowing and "protective falsehoods" might also be achieved by expanding the grounds for asylum, so that claimants do not feel the need to fit their experiences into rigidly pre-set categories. We might also consider making it more difficult for claimants to adjust their stories-for example, by not providing claimants with too much advance information about

\footnotetext{
${ }^{242}$ Barsky, "The Interpreter as Intercultural Agent", supra, note 189 at 50; Rousseau, Crépeau, Foxen \& Houle, "The Complexity of Determining Refugeehood", supra, note 11.

${ }^{243}$ See Anthony Good, Anthropology and Expertise in the Asylum Courts (New York: RoutledgeCavendish, 2007).

${ }^{244}$ Canada has had a guest worker program for several years (see Citizenship and Immigration Canada, online: http:/www.cic.gc.ca/english/work/), although it has been criticized by human rights advocates_-see for example, Carol Boar "No way to treat a guest worker"'(April 13, 2007) The Toronto Star, online: http://www.thestar.com/article/202587. It is not currently possible to determine whether there are fewer refugee claimants as a result, or, for that matter, whether there is a change in the percentage of fortune seekers .

${ }^{245}$ Barsky, "Narratology" supra, note 26 at 298.
} 
our working definitions in order to discourage "tailoring". For instance, as Barsky suggests, we might decline to include such definitions in instructions with respect to written statements ${ }^{246}$-although a correct balance must be struck between discouraging false stories and allowing claimants to know the case they have to meet.

We might also try to limit the contact claimants have with "story shapers", such as the one who helped Caroline. These story shapers are distorting elements in the communication between claimant and decision maker. They serve to mediate, filter and, sometimes, completely obscure, the asylum seeker's true experiences. Another approach might be to regulate the contact IRB interpreters have with claimants outside the hearing room. Some of these interpreters have been known to work as "client catchers" for individual lawyers in their spare time. ${ }^{247}$ Often an interpreter is the first friendly contact a claimant will have upon arrival at the port of entry, and these interpreters have been known to offer to help claimants navigate the system or settle in. While many interpreters do this work out of the goodness of their heart, the potential for abuse and conflict of interest is there. Because they are part of a select group that have detailed knowledge of what goes on in the hearing room, they are ideally placed to construct a "winning" story for purchase and sale. If interpreters were professionalized—say, given offices inside the IRB and paid salaries (as opposed to being paid by the case) they might not be tempted to have extra-curricular contact with claimants - and the supply of stories for purchase might be reduced. ${ }^{248}$ Measures which prevent immigration consultants from representing claimants might also stem the practice of "story shaping". Although a lawyer might still be tempted to fabricate or embellish a story, the professional code of ethics to which lawyers are subject should act as a deterrent in most cases. Immigration consultants, conversely, are not necessarily subject to any professional standards whatsoever, yet claimants

\footnotetext{
246 Barsky, Constructing a Productive Other, supra, note 20, at 119.

${ }^{247}$ This assertion is based on anecdotal evidence. For an illustration of the role of the interpreter see Showler, Refugee Sandwich, supra, note 224 at 161-181.

${ }^{248}$ Hathaway suggested this as well. See Rebuilding Trust, supra, note 49, at 73.
} 
are likely to trust in them, since they are often members of the same ethnic community. ${ }^{249}$

Our suggestions for improving credibility assessment in refugee status determination have centered on coping with uncertainty, reducing narrative, dealing constructively with prior statements, making use of cultural information, and discouraging borrowing and substitution of stories. All of these strategies seem capable of enhancing accuracy in decision making because they help break down communicative barriers between decision makers and claimants and increase the flow of reliable information. Juridical sensitivity to context could be achieved if education around lie-detection and the sequellae of forced exile served as a back-drop to these new approaches to credibility assessment. In aid of efficiency, once again, it would seem to be economical to make use of the wealth of academic research capable of assisting asylum decision makers with credibility assessment; this research has already been completed and subsidized. Conversely, efficiency is eroded when hearing time is wasted on impossible and ultimately unrevealing tasks such reconciling prior and current statements, relying on nondiagnostic cues for lie detection and other methods of assessing stories that are not reflective of the refugee context.

\subsubsection{Conclusion on ideological reform}

Upon reflection, the three new approaches suggested in this paper (a new decision maker profile, new hearing room dynamic and a new approach to credibility assessment) seem to be united by one theme: they privilege human-tohuman contact between claimant and decision maker in the asylum process. Measures that promote openness and receptivity and reduce falsity, distortion and mediation may encourage asylum decision makers to learn the refugee experience and to relate to refugees as fellow human beings, rather than crafty "others" coming to deplete the host community's scarce resources. Selecting professional decision makers capable of rising above their own prejudices and inaccurate

\footnotetext{
${ }^{249}$ The government of Canada has taken steps to regulate immigration consultants. See Bill C-35, An Act to Amend the Immigration and Refugee Protection Act, SC 2011 c-8.
} 
assumptions, creating an adjudicative atmosphere where refugees can tell their stories in their own way and in their own words without having to resort to strategic lies or borrowing stories, all help to clear the channels of communication and information, and strip the process down to its essentials. And, according to the available empirical evidence, this direct human-to-human contact is actually something which refugees themselves have been seeking from the decision making process. ${ }^{250}$ The host community benefits as well. The new approaches have the potential to better identify those truly in need and, by extension, those who are not genuine refugees. A high level of both contextual and claimantspecific knowledge will ideally help make the refugee hearing room "a social space where imagination is given free reign but is well stocked with accurate stories about the world that protect it from the extremes of credulity and disbelief". ${ }^{251}$

\footnotetext{
${ }^{250}$ Canadian Council for Refugees, The Experience of Refugee Claimants, note 70, supra at 46. See also David Ngaruri Kenney \& Philip G Shrag, Asylum Denied: A Refugee's Struggle for Safety in America (Berkley:, U of California Press, 2008) at 152 and 251-252 where the author describes his distress when both the Immigration Judge hearing his case and the appellate judges of the $4^{\text {th }}$ Circuit Court of Appeals refuse to look at him.

${ }^{251}$ Kirmayer, supra, note 11 at 183.
} 


\section{Conclusion}

We have presented a comprehensive structural and ideological reform proposal for refugee status determination in Canada designed to advance the interests of stakeholders. We have explored an alternative model for refugee determination, new approaches to fact finding and credibility assessment in the asylum context, and advocated for a shift in systemic values. The alternative structural model proposed envisions moving from a quasi-judicial initial determination body to either a wholly-judicial one, similar to the Tax Court of Canada, or a para-judicial/interdisciplinary one, modeled on the Tribunal administratif du Québec. New approaches to fact finding and credibility assessment have centered on the notion that truth in the asylum context is relative, not fixed, and that dialogue and unfettered refugee speech should be privileged as much as possible in the hearing room. The new systemic values advanced have been accuracy (achieved through undistorted reception of information and dissemination of high quality contextual information), efficiency (achieved through simplicity, economy and timeliness being built into adjudicative structures) and juridical sensitivity to context (achieved through appropriate selection criteria, context-specific interdisciplinary training, and the fostering of a juristic culture around asylum decision making). The proposals find their inspiration in empirical data, interdisciplinary academic thought and previous reform initiatives, and are designed to conform to the challenges inherent in refugee status determination.

Again, as indicated at the outset, the proposals set out in this thesis are not intended to be definitive - but simply to serve as a springboard for further discussion around sustainable and generally acceptable reform to Canada's asylum system. They could be adopted in whole or in part. Where more than one alternative has been presented, there is no intention that these alternatives be seen as "opposing" each other, but simply as different manifestations of the kinds of institutional changes that could help avoid the pitfalls of the current system. 
Some aspects of the reform project are already being tried — either in Canada or somewhere else, either in the asylum context or in some other context.

There appear to be three unifying themes that underlie the proposed structures and approaches. The first, as alluded to earlier, is a call for greater ontological proximity between asylum seeker, decision maker and host community, as well as a simplified relationship between the three. The second is a tendency towards higher status for asylum decision makers - a desire for them to revert to the sages and high priests of asylum's history. The third is a movement towards an egalitarian status for asylum seekers, one where they are not cast as suppliants in a merciful hierarchy, but revealed as having agency, power and rights. For example, the theme of ontological proximity is reflected in measures that decrease communicative distortion, encourage dialogue, champion asylum education and de-clutter the process. The theme of decision maker as high priest is most directly reflected in the Asylum Court proposal, but also in those measures designed to professionalize first instance decision making generally. And the theme of egalitarianism is reflected in the dialogic hearing room, the shared benefits of storytelling, and measures that attempt to deconstruct pre-conceived notions of "refugees" by allowing them to speak in their own authentic voices. While there may be tension between these themes at points, they converge to create an asylum system that is an instrument for the promotion of human rights.

Nonetheless, we should be under no delusions. A reform project which accommodates the needs of refugees (even partially) will have difficulty finding favour with the governments of the day-despite the fact that individual members of the general public, when confronted with the human face of asylum, might be supportive of such a project. The path to radical reform must be paved, not just with good intentions, but with concrete plans for countering the anti-refugee discourse that prevails in many host societies. We must find ways to encourage the populace to reconnect with asylum's altruistic and humanitarian roots, and demand that governments do the same. 


\section{Bibliography}

\section{Legislation}

Administrative Justice Act, RSQ c J-3.

Balanced Refugee Reform Act, SC 2010, c 8.

Protecting Canada's Immigration System Act (Bill C-31), SC 2012, c 17,

Bill C-35, An Act to Amend the Immigration and Refugee Protection Act, SC 2011

c 8 .

Code of Federal Regulations, Title 8 (US).

Convention Relating to the Status of Refugees, 28 July 1951, UNTS 137, Can TS

1969 No 6.

Corrections and Conditional Release Act, SC 1992 c 20.

Federal Courts Act, RSC 1985 c F-7.

Immigration Act 2009 (NZ) 2009/51.

Immigration and Refugee Protection Act, SC 2001 c 7

Order Respecting the Interim Federal Health Program, 2012 PC 2012-433, SI/2012-25, April 25, 2012, as amended.

Tax Court of Canada Act, RSC 1985 cT-2.

\section{Jurisprudence}

Addo v MEI, (1992) 142 NR 170.

Adjei v MEI, [1989] 132 NR 24.

Ali v MEI, (1992) A-236-91, available on QL.

Armson v MEI, (1989) 9 Imm LR (2d) 150 (FCA).

Attakora v MEI, (1989) 99 NR 168 (FCA).

Ba v Holder 2012 WL 2146323 (CA2)

Bains v MEI, (1990) 109 NR 239 (FCA).

Chaudri v MEI,(1986) 69 NR 114.

Chen v MEI,(1993) A-30-91, available on QL.

Cheung v MCI, (1993) 19 Imm LR 81 (FCA.

Dhillon v MEI, (1990) 131 NR 62.

Farhadi v MCI, (2000) 182 FTR 98 (FCA).

Grama v MCI, 2004 FC 1030.

Haitian Refugee Center v Smith 676 F 2d 1023 (5 $5^{\text {th }}$ Cir, 1982).

Hilo v. MEI, (1991) 130 NR 236.

Jocelyn v MEI, (1991) 15 Imm LR (2d) 272.

Kaur v MEI, [1990] 2 FC 209 (FCA).

Krishnapillai v MCI,[2002] 3 FC 274 (CA).

Maldonado v MEI,[1980] 31 NR 34 (FCA).

MB c Quebec (Emploi et Solidarité), 2001 CanLII 37053 (QC TAQ)

Mahathmasseelan v MEI,(1991) 137 NR 1.

Molnar v MCI, 2012 FC 530. 
Orantes-Hernandez v Meese 685 F Supp 1488 (CD Cal, 1988).

Owusu-Ansah v MEI, (1989) 8 Imm LR (2d) 212 (FCA).

Ozer v MCI, 2008 FC 1257.

Plaintiff M61/2010E v Commonwealth of Australia; Plaintiff M69 of $2010 v$ Commonwealth of Australia (2010) 274 ALR 14 (HC).

$R$ on the application of Javed and others $v$ Secretary of State for the Home Department and Another [2002] QB129.

$R$ on the application of Zakir Husan and the Secretary of State for the Home Department [2005] EWHC 189 (Admin).

$R v$ Moses, 71 C.C.C. (3d) 347

$R v$ Secretary of State for the Home Department ex parte Adam et al (2007) 1 All ER 951.

Ramirez v MEI,(1992) 135 NR 390.

Rasaratnam v MEI, [1992] 140 NR 138.

Sabaratnam v MEI, (1992) A-536-90, available on QL.

Salibian v MEI, (1990) 113 NR 123.

Surujpal v MEI, (1985) 60 NR 73.

Veeravagu v MEI, (FCA A-630-89 available on QL.

Victoria Council for Civil Liberties Incorporated v Min for Imm \& Multicultural Affairs (2001) 182 ALR 617.

$W u v$ MEI (1992) FCA A-369-89 available on QL.

Xue v. Board of Immigration Appeals 439 F.3d 111(2006)

Yaliniz v. Canada (Minister of Employment and Immigration) (1988), 7 Imm LR

(2d) 163 (CA).

Yusuf v MEI (1991) 133 NR 391.

\section{Secondary material: monographs}

Abella, Irving and Harold Troper. Barsky, Robert. Constructing a Productive Other: Discourse Theory and the Convention Refugee Hearing (Philadelphia: John Benjamins Publishing Company, 1994).

Birnie, Lisa Hobbs. A Rock and a Hard Place: Inside Canada's Parole Board (Toronto: Macmillan, 1990).

Good, Anthony. Anthropology and Expertise in the Asylum Courts (New York: Routledge-Cavendish, 2007).

Kenney, David Ngaruri \& Philip G Shrag. Asylum Denied: A Refugee's Struggle for Safety in America (Berkley:, U of California Press, 2008).

Mengestu, Dinaw. How to Read the Air (New York: Riverhead Books, 2010).

Monahan, Patrick and Elie S Roth. Federal Regulation of Charities: A Critical Assessment of Recent Proposals for Legislative and Regulatory Reform Toronto: York, University, 2000).

Moorehead, Caroline. Human Cargo (New York:, Henry Holt \& Company 2005). 
Morris, Lydia. Asylum, Welfare and the Cosmopolitan Ideal: A Sociology of Rights (New York: Routledge, 2010).

Price, Mathew. Rethinking Asylum: History, Purpose and Limits (New York: Cambridge University Press, 2009).

Rabben, Linda. Give Refuge to the Stranger: the Past, Present and Future of Sanctuary (California: Left Coast Press, 2011).

Showler, Peter. Refugee Sandwich (Montreal \& Kingston: McGill-Queen's University Press 2006).

\section{Secondary material: articles}

Appleby, Ronald \& A. Lorne Greenspoon. "The Tax Court of Canada and the Tax Appeal Process" (1984-1985) 5 Advoc. Q. 332 at 332.

Barsky, Robert. "The Interpreter as Intercultural Agent in Convention Refugee Hearings" (1996) 2:1 The Translator 45, at 50.

Barsky, Robert. "Narratology and the Convention Refugee Claim: Reontologizing the subject in Canadian Immigration Hearings discourse" (1988) 1:3 Discours Social 265.

Byrne, Rosemary. "Assessing Testimonial Evidence in Asylum Proceedings: Guiding Standards from the International Criminal Tribunals" (2007) 19:4 Int'l J Refugee L 609, at 628.

Cameron, Hilary Evans. "Refugee Status Determination and Limits of Memory" (2010) 22:4 Int'l J Refugee L 2010469.

Caplow, Stacy. "After the Flood: The Legacy of the 'Surge' of Federal Immigration Appeals" (2012) 7:1 Nw J L \& Soc Pol'y 1.

Cohen, Juliet. "Questions of Credibility: Omissions, Discrepancies and Errors of Recall in the Testimony of Asylum Seekers," 2001 13:3 Int J Ref L 293.

Comtois, Suzanne. "Le Tribunal Administratif du Québec: Un Tribunal

Suffisamment Indépendent?" (2000-2001) 14 Can J Admin L \& Prac 127.

Crépeau, Francois \& Delphine Nakache. "Critical Spaces in the Canadian Refugee Determination System; 1989-2002” (2008) 20:1 Int'1 J Refugee L 50.

Delgado, Richard. "Storytelling for Oppositionists and Others: A Plea for Narrative" (1989) 87 Mich Law Review 2411.

Desantis, Alan. "Caught Between Two Worlds: Bakhtin's Dialogism in the Exile Experience", Journal of Refugee Studies (2001) 14:1 1.

Durst, Ilene. "Lost in Translation; Why Due Process Demands Deference to the Refugee's Narrative" (2000) 53:1 Rutgers L Rev 127.

Eastmond, Marita. "Stories as Lived Experience: Narratives in Forced Migration Research" (2007) 20:2 Journal of Refugee Studies 248.

Garant, Jêrome. "Le Tribunal Administratif du Québec : La Procédure et La Preuve" (LLM Thesis, University of Laval Faculty of Law, 2004) [unpublished]. Ghorashi, Halleh. "Giving Silence a Chance: The Importance of Life Stories for Research on Refugees" (2007) 21:1 J of Refugee Studies 117 at 127. 
Greene, Ian \& Paul Shaffer. "Leave to Appeal and Leave to Commence Judicial Review in Canada's Refugee Status Determination System: Is the Process Fair?" (1992) 4 Int'1 J Refugee L 71.

Gorlick, Brian. "UNHCR Working Paper No. 119: Improving decision-making in asylum determination" UNHCR, August 2005.

Gould, Jon, Colleen Sheppard \& Johannes Wheeldon. "A Refugee from

Justice? Disparate Treatment in the Federal Court of Canada" (2010) 32 Law \& Pol'y 454.

Hardy, Cynthia. "Refugee Determination: Power and Resistance in Systems of Foucauldian Power" (2003) 35:4 Administration and Society 462.

Harvey, Colin. "Judging Asylum" in Prakash Shah, ed, The Challenge of Asylum to Legal Systems (London: Cavendish Publishing Limited, 2005) 169.

Herlihy, Jane \& Stuart Turner. "The Psychology of Seeking Protection" (2009) Int'l J Refugee L 21:2 171.

Herlihy, Jane, Kate Gleeson \& Stuart Turner. "What Assumptions about Human Behaviour Underlie Asylum Judgments?” (2010) 22:3 Int'1 J Refugee L 351.

Herlihy, Jane, Peter Scragg \& Stuart Turner. "Discrepancies in autobiographical memories - implications for the assessment of asylum seeker: repeated interviews study", BMJ 2002:324:324-7.

Juss, Satwinder. "Towards a Morally Legitimate Reform of Refugee Law: The Uses of Cultural Jurisprudence" (1998) 11 Harv Hum Rts J 312.

Kagan, Michael. "Is Truth in the Eye of the Beholder? Objective Credibility Assessment in Refugee Status Determination", 2002-2003 17 Geo Imm L J 367.

Kalin, Walter. "Troubled Communication: Cross Cultural Misunderstandings in the Asylum-Hearing", (1986) 20:2 International Migration Review 230.

Kirmayer, Lawrence. "Failures of Imagination: The Refugee's Narrative in Psychiatry"(2003) 10:2 Anthropology \& Medicine 167.

Knudsen, John Chr. "When Trust is on Trial: Negotiating Refugee Narratives" in Daniel, E Valentine \& John Chr Kndusen, eds, Mistrusting Refugees (Berkeley: University of California Press, 1995) 13.

Lustig, Stuart L. "Symptoms of Trauma among Political Asylum Applicants: Don't be Fooled" (2008) Hastings International and Comparative Law Review 725.

MacGregor, Ian et al. The Development of the Tax Court of Canada: Status, Jurisdiction, and Stature, (2010) 58 Can Tax J (supp) 87.

Macklin, Audrey. "Asylum and the Rule of Law in Canada: Hearing the Other (Side)" in Kneebone, Susan, ed, Refugees, Asylum Seekers and the Rule of Law (New York: Cambridge University Press, 2009) 78.

Martin, David. "Reforming Asylum Adjudication: On Navigating the Coast of Bohemia" (1990) 138:5 U Pa L R 1247 at 1362.

Millbank, Jenni . " 'The Ring of Truth': A Case Study of Credibility Assessment in Particular Social Group Refugee Determinations" (2009) 21:1 Int'1 J Refugee $\mathrm{L} 1$, at 30 . 
Rehaag, Sean. "The Luck of the Draw? Judicial Review of Refugee

Determinations in the Federal Court of Canada (2005-2010)" (2012) 8:3 Osgoode CLPE Research Paper Series 1.

Rehaag, Sean. "Troubling Patterns in Canadian Refugee Adjudication" (2006) 39:2 Ottawa L Rev 1.

Rider, Erin. Negotiating Uncertainty in the Right to Asylee Status: Reconceptualizing Agency from a Space of Liminality, PHD Dissertation, Texas Woman's University, 2010 [unpublished], at 148-149.

Rose, Joseph. "The Asylum Seeker: The Proverbial Rat in the Evidentiary Maze of Asylum Law? Some Suggestions for Reform”, (1994-1995) 24 Sw UL Rev 473 at 499.

Rousseau, Cecile \& Patricia Foxen. "Constructing and Deconstructing the Myth of the Lying Refugee: Paradoxes of Power and Justice in an Administrative Immigration Tribunal" in Els Van Dongen \& Sylvie Fainzang, eds Lying and Illness: Power and Performance (Amsterdam: Het Spinhuis, 2006) 56.

Rousseau, Cecile \& Patricia Foxen. "Look me in the Eye: Empathy and the Transmission of Trauma in the Refugee Determination Process" (2010) 47 Transcultural Psychiatry 70.

Rousseau, Cecile et al. "The Complexity of Determining Refugeehood: A Multidisciplinary Analysis of the Decision-making Process of the Canadian Immigration and Refugee Board" (2002) 15:1 Journal of Refugee Studies 43.

Saniotis, Arthur. "Polemics of Healing: Storytelling, Refugees and Futures" (2008) 12:4 J of Futures Studies 1.

Shea, David P. "Perspective and Production: Structuring Conversational Participation across Cultural Borders" (1994) 4:3 Pragmatics 357.

Shuman, Amy \& Carol Bohmer. "Representing Trauma: Political Asylum Narrative", (2004) 117:466 Journal of American Folklore 394.

Turner, Stuart. "Torture, Refuge and Trust" in E.Valentine Daniel \& John Chr Kndusen, eds, Mistrusting Refugees (Berkeley: University of California Press, 1995) 56.

Vrij, A. "Why professionals fail to catch liars and how they can improve" (2004) 9 Legal and Criminological Psychology 159.

\section{Other materials}

Administrative Office of the United States Courts. 2011 Annual Report of the Director: Judicial Business of the United States Courts (Washington, DC: Administrative Office of the United States Courts, 2012).

American Bar Association. Reforming the Immigration System: Proposals to Promote Independence, Fairness, Efficiency and Professionalism in the Adjudication of Removal Cases, 2010. 
Australian Government, Department of Immigration and Citizenship. Asylum Trends Australia 2010-2011 Annual Publication (Canberra: Systems, Program Evidence and Knowledge Section of the Department of Immigration and Citizenship (DIAC)).

Bastarache, Michel. Commission d'enquête sur le processus de nomination des juges du Québec: synthèse, (Québec: Les Publications du Québec, 2011).

Beaudoin, Lise I. "Projet de loi 4 sur la justice administrative, La présence de juristes sur les banc doit être maintenue",(2003) 35:16 Journal du Barreau.

Canadian Council for Refugees. The Experience of Refugee Claimants at Refugee Hearings at the Immigration and Refugee Board, (7 January, 2012), online: http://ccrweb.ca/files/irb_hearings_report_final.pdf.

Canadian Forum on Civil Justice. Public Perceptions of the Role of the Judiciary (Edmonton: Canadian Forum on Civil Justice, University of Alberta, 2005).

Citizenship and Immigration Canada, "Backgrounder-Summary of Changes to Canada's Refugee System in the Protecting Canada's Immigration System Act", February 16, 2012, online:

http://www.cic.gc.ca/english/department/media/backgrounders/2012/2012-0216f.asp.

Citizenship and Immigration Canada. "Formative Evaluation of the Pre-Removal Risk Assessment Programme"(2008), online:

http://www.cic.gc.ca/english/resources/evaluation/prra/index.asp

Citizenship and Immigration Canada. "Guide 6000: Convention Refugees Abroad and Humanitarian-Protected Persons", online:

http://www.cic.gc.ca/english/information/applications/guides/E16000TOC.asp.

Collacott, Martin. "Canada's Inadequate Response to Terrorism: The Need for Policy Reform” (2006:Fraser Institute).

Commissioner of Federal Judicial Affairs. Assessment Criteria, Candidates for Federal Judicial Appointment, online: http://www.fja-cmf.gc.ca/appointmentsnominations/assessment-evaluation-eng.html.

Courts Administration Service. Annual Report 2010-2011 (Ottawa: Courts Administration Service, 2012).

Dolnick, Sam. "Immigrants May Be Fed False Stories to Bolster Asylum Pleas" The New York Times (11 July, 2011). 
European Council for Refugees and Exiles (ECRE). "Asylum Lottery in the EU" online: http://www.ecre.org/.

Fletcher, Joseph F and Paul Howe. Public Opinion and the Courts (Montreal: Institute for Research on Public Policy, 2000).

"Government Prepares for Public Relations War over Refugees"(17 March, 2010), Embassy Magazine.

Hathaway, James. Rebuilding Trust: Report of the Review of Fundamental Justice in Information Gathering and Dissemination at the Immigration and Refugee Board of Canada, December, 1993, online:

repository.forcedmigration.org/pdf/?pid=fmo:1136

House of Commons, , Standing Committee on Citizenship and Immigration, $1^{\text {st }}$ Sess, $41^{\text {st }}$ Parl, Evidence of Meeting 34, May 1, 2012. at 1025 (The Hon Chungsen Leung).

House of Commons, Standing Committee on Citizenship and Immigration, $1^{\text {st }}$ Sess, $41^{\text {st }}$ Parl, Evidence of Meeting 36, May 2, 2012 at 1250 (Hon Roxanne James).

Immigration and Refugee Board of Canada. Performance Report for the Period Ending March 31, 1996 (Ottawa: Minister of Public Works and Government Services, 1996).

Immigration and Refugee Board of Canada, Performance Report 2010-2011 (Ottawa: Immigration and Refugee Board, 2011).

Law Reform Commission of Canada. The Determination of Refugee Status in Canada: A Review of the Procedure, Draft Final Report, March 1992.

Mehta, Suketa. "The Asylum Seeker: For a chance at a better life, it helps to make your story worse", The New Yorker,(1 August, 2011) 32

Ontario Courts of Justice. Annual Report 2008-2009 (Toronto: Ontario Courts of Justice, 2010).

Parole Board of Canada. Parole and Public Safety: a public forum, Final Report (Ottawa: Parole Board of Canada, 2001), online: http://pbcclcc.gc.ca/rprts/ccjareport-eng.shtml\#4

Parole Board of Canada. Performance Report 2009-2010 (Ottawa: Parole Board of Canada, 2011). 
Parole Board of Canada. Research Report "2009 Victim Questionnaire Results" (Ottawa: Parole Board of Canada, 2010), online: http://pbcclcc.gc.ca/rprts/quest/quest09-eng.pdf

Plaut, W. Gunther. Refugee determination in Canada; A report to the Honourable Flora Macdonald, Minister of Employment and Immigration (Canada: Minister of Supply and Services Canada, 1985).

"Refugee Crackdown Draws Fire” (February 17, 2012), Montreal Gazette.

"Refugee Rules Okay: report, Canadians hesitant to reform system" (27 November, 2010), Montreal Gazette.

Senate of Australia. A Sanctuary under Review: An Examination of Australia's Refugee and Humanitarian Processes (Canberra: Senate of Australia, 2000).

Showler, Peter. Fair Fast and Final: Reforming Canada's Refugee System, (Ottawa: The Maytree Foundation, 2009).

"Tories Aim to Fix 'Broken' Immigration System" (February 16, 2012), CTV News, online: http://www.ctv.ca/CTVNews/TopStories/20120216/refugeereform-bill-immigration-changes-120216

Tribunal administratif du Quebec. 2010-2011 Annual Report (Quebec: Tribunal administratif du Quebec, 2012).

UNHCR. "Note on fair and efficient asylum procedures: a non-exhaustive overview of applicable international standards" (2005).

University of Ottawa, Human Rights Research and Education Centre, Refugee Forum. National Asylum Systems (2010), online: http://www.cdp-

hrc.uottawa.ca/projects/refugee-forum/projects/systems/introduction.php. 